Historic, archived document

Do not assume content reflects current scientific knowledge, policies, or practices. 



\section{ADVANCE OFFERING}

\section{High Quality \\ BULBS}

For Autumn Planting

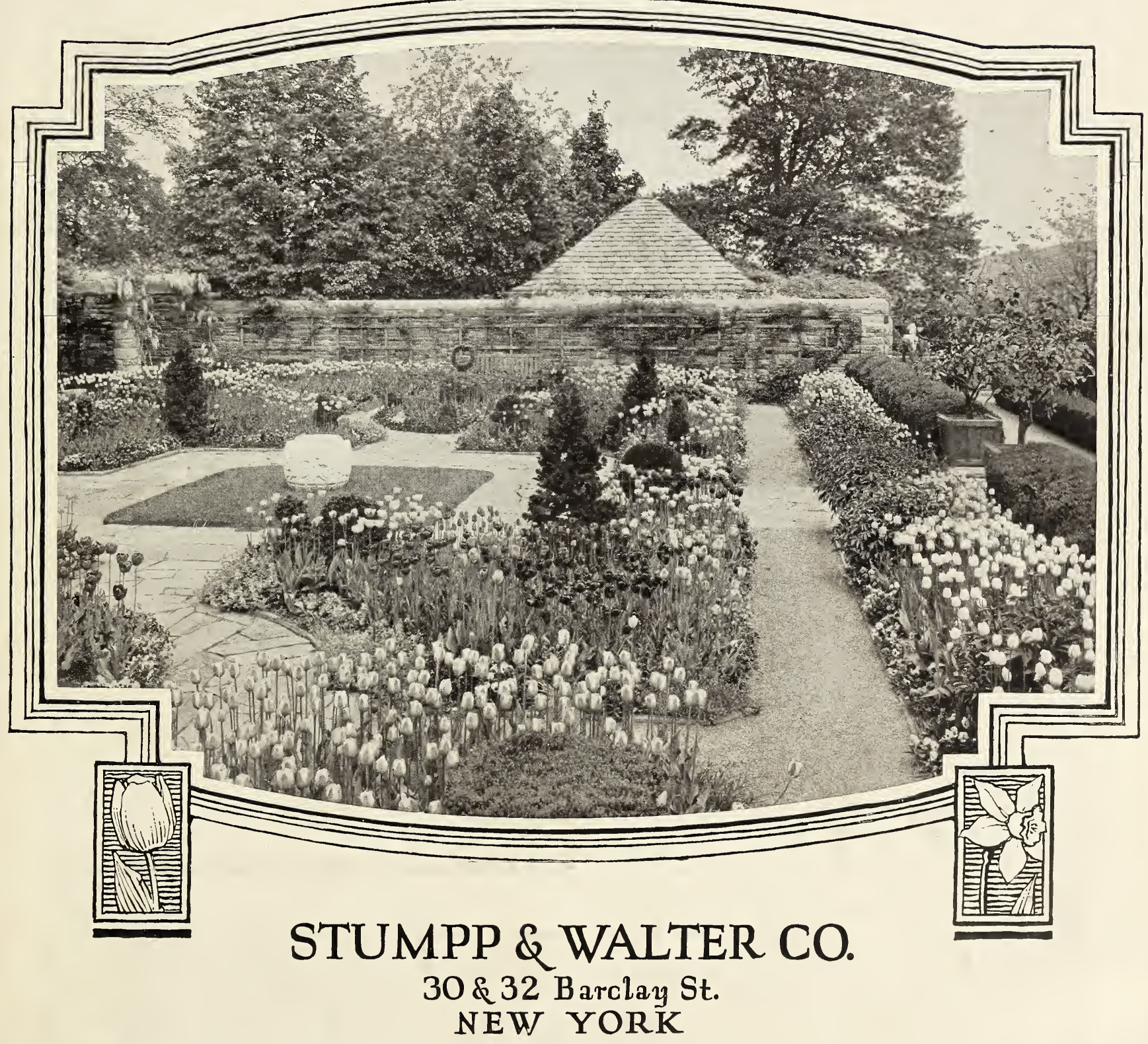




\section{INTRODUCTION}

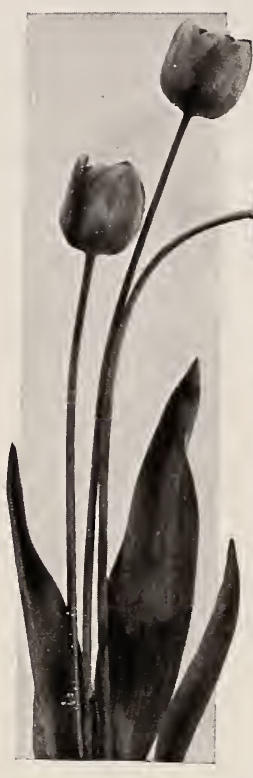

$\mathrm{T}$ WENTY-FIVE years seems a Iong time to go back to the days when, on Saturday, school books were laid aside for a jaunt in the public parks. It was Easter time. The beautiful display in the conservatories of Prospect Park, Brooklyn, the writer's birthplace, is still vividly recalled - the wonder of it all and how it impressed me! Many thousands of blooms of Tulips, Daffodils and Hyacinths, grown in earthenware pots and florists' flats-solid masses of color.

The gardener seemed delighted to answer questions. "We plant all these bulbs in the autumn, my boy," he said. "You know all these flowers are already formed in the bulbs." Then he quickly told the story of how simple their culture was.

This fascination of boyhood days has happily become a perennial joy, and now as I write of our Advance Offering of high quality bulbs for autumn planting, I do so with the earnest desire, that, if you are not acquainted with the fact that you can have flowers in your home from Christmas to Easter, and in your garden, no matter how small, from Easter until Memorial Day, you try growing a few this year.

Purpose of Illustrations. The illustrations throughout our Advance Offering have been Purpose of Illustrations. made from actual photographs of gardens of some of our patrons to whom we have supplied bulbs, in many cases, for the past ten or more years, and are used with the hope that they may assist the reader to better visualize the possibilities of their use.

\section{HIGH OUAITY BULBS WHY WE USE THE EXPRESSION AND HIGH QUALII BULBS HOW WE ENDEAVOR TO MAINTAIN IT}

High Quality Bulbs are bulbs of proper flowering age, grown in a careful manner; thoroughly ripened and cured; and selected for size. The bulbs listed in this Advance Offering are grown in Bermuda, California, Japan, France, but principally in Holland. We contract with growers only for each variety listed. No grower in Holland, for example, grows all the varieties of Dutch bulbs offered by us. Therefore, we place advance contracts for the various varieties with specialists. The bulbs are carefully packed and shipped to us in the autumn.

On their arrival in New York they are immediately unpacked so as to avoid becoming "heated" and carefully arranged in our own building, examined and passed on by thoroughly trained men.

Special Import Orders. We do not solicit your order on the basis of special importation and subject it to the possibility of long transportation delay from the country of origin to your home, and then have you assume the risk of having the bulbs arrive "heated," thereby destroying the embryo flower. Quality versus Price. We give complete assurance that no better bulbs can be purchased from any think so when you get our bulbs, we ask you to return them, transportation collect.

A careful perusal and comparison of the prices will convince you that they are lower than those of some Specialists who offer good quality. This is due to the fact that on moderate-priced varieties of Early Tulips, Darwins, Breeders, Cottage Tulips, Daffodils, and Hyacinths we contract for large quantities and do not send miscellaneous small orders to Holland dealers as we receive them from you.

\section{SPECIAL NOTICE}

The Federal Horticultural Board of the Department of Agriculture has recently announced that it will permit, for a period of three years, the importation of what is generally termed in the trade the following miscellaneous Bulbs: Chionodoxa, Eranthis, Fritillaria, Galanthus (Snowdrops), GrapeHyacinths, Ixias, and Scillas. We urge our patrons to avail themselves of this opportunity to plant these beautiful bulbs in their gardens, as after this period they will be difficult to procure.

Special Quarantine on all Narcissi, or Daffodils. They have also announced that after three years they will not permit the further importation of any variety of Narcissi, or Daffodils. We urge our patrons to plant liberally of these bulbs each year so that their gardens will be well supplied, as, in our opinion, after this time they will not be available in any desirable quantity. See back cover page for Special Offer for Naturalizing.

\section{STUMPP \& WALTER CO.}

GEORGE G. STUMPP, President JULIAN H. WALTER, Treasurer
NEW YORK
THOMAS F, KEARNEY, Ass't Treasurer WILLIAM A. SPERLING, Secretary 


\section{Why We Ask for Your Order by July 15}

Many of the new and rare varieties of Darwin, Breeder, and Cottage Tulips, Hyacinths, and Daffodils are only obtainable in small quantities, due to the small stocks available. We have contracted, in many instances, for the entire stock of these novelties from the introducers in Holland, and after these quantities are engaged we will be unable to offer a further supply.

By sending in your order by July I5 you also help us to keep our organization busy during the summer months, making preparations in advance of the delivery of the bulbs, you thereby getting them sooner than if ordered in the autumn. Do not wait until July but send us your order as soon as you receive our catalogue.

\section{TIME OF DELIVERY}

Bulbs and roots mature and ripen during the late summer and autumn and shipments will be made as follows in the absence of instructions to the contrary.

SEPTEMBER -includes Lilium Harrisii, Lilium formosum,

Lilium candidum, Freesias, Paper-White and Grand Soleil d'Or Narcissi, and Bulbous Irises.

OCTOBER OR MAIN SHIPMENT includes the general line of bulbs, such as Hyacinths, Tulips, Crocus, and Callas.

NOVEMBER AND DECEMBER-includes Liliums and Lilies-

of-the-Valley. We endeavor to get all Liliums and Lilies-ofthe-Valley shipped by early December. We, however, frequently do not receive the three varieties of Japanese Lilies, as listed on pages 26 and 27 , namely, auratum, speciosum magnificum, and album from the Orient until the ground has become frozen in some parts of the country.

These may be kept in a cool cellar and planted in the spring, or, if you so advise, we can ship these three items in the spring.

\section{TERMS OF PAYMENT}

We do not send bulbs C. O. D., but ship your order when bulbs arrive, mailing invoices at the same time, and all bills are due in 30 days, net.

For those who desire to send us cash with the order, and thereby forfeit the use of the interest on the same from the time they send it until bulbs are shipped, we ask that they deduct a cash discount of 5 per cent from their order to compensate them for this loss.

WE FURNISH ALL BULBS, 6 of a variety, at the dozen rate;

25 of a variety at 100 rate; 250 of a variety at 1,000 rate.

\section{SHIPPING INSTRUGTIONS}

We ask for full shipping directions. State whether bulbs are to be shipped by parcel post or express, and by what route. In the absence of instructions we ship by whatever method and route we believe best.

Guarantees. Our method of handling bulbs practically precludes the possibility of stock proving unsatisfactory, and the perGuarantees. centage of complaints is really negligible. We guarantee all bulbs sent out to be true to name and of proper flowering age. It is, however, impracticable, owing to contingencies of soil, climate, season, or faulty planting, to guarantee that all bulbs we send out will flower satisfactorily. We make complete trials of all the varieties we send out at our own trial-grounds and know, from extended experience, that all our bulbs flower satisfactorily if given just ordinary attention.

Planning the Garden. In the past we have had many customers and friends who have asked us to help them plan their bulb$\begin{array}{ll}\text { COLOR schemES } & \text { gardens. We will be very glad to make suggestions, if you } \\ & \text { or borders. Please give planting areas when sending same. }\end{array}$

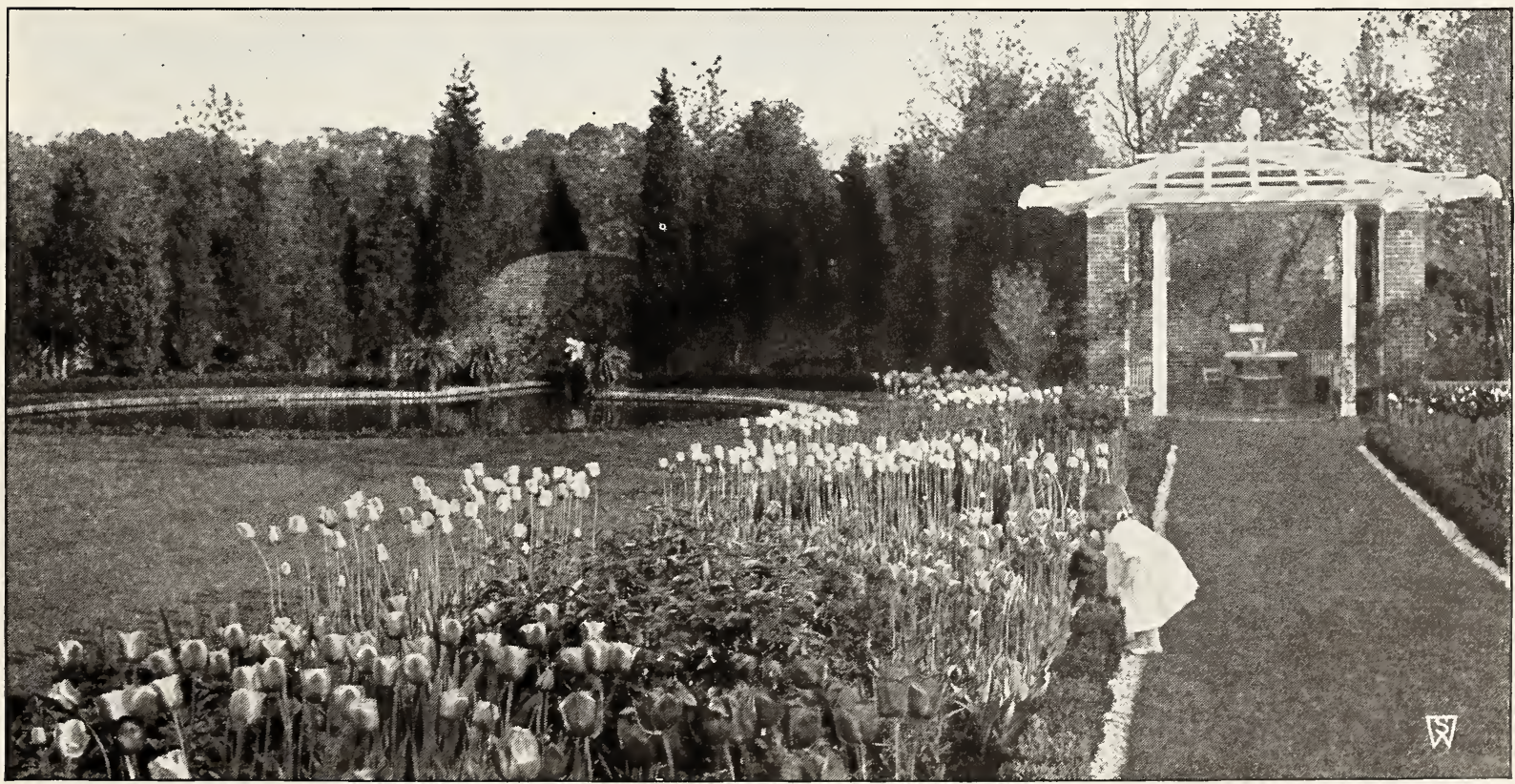

Darwin, Breeder, and Cottage Tulips in flower during May, planted in irregular clumps among hardy perennials which happily take their place after the Tulips have finished blooming. The irresistible appeal which these gorgeous, easily-grown flowers make to our children is noted. It was the writer's privilege and pleasure to snap this little girl unawares.

Bulbous Flowers in Your Home from Christmas to Easter, On page 31 of this special offering we have endeavored to planted in the autumn in flower-pots and grown in successive batches in the living-room window or conservatory during the winter months. 


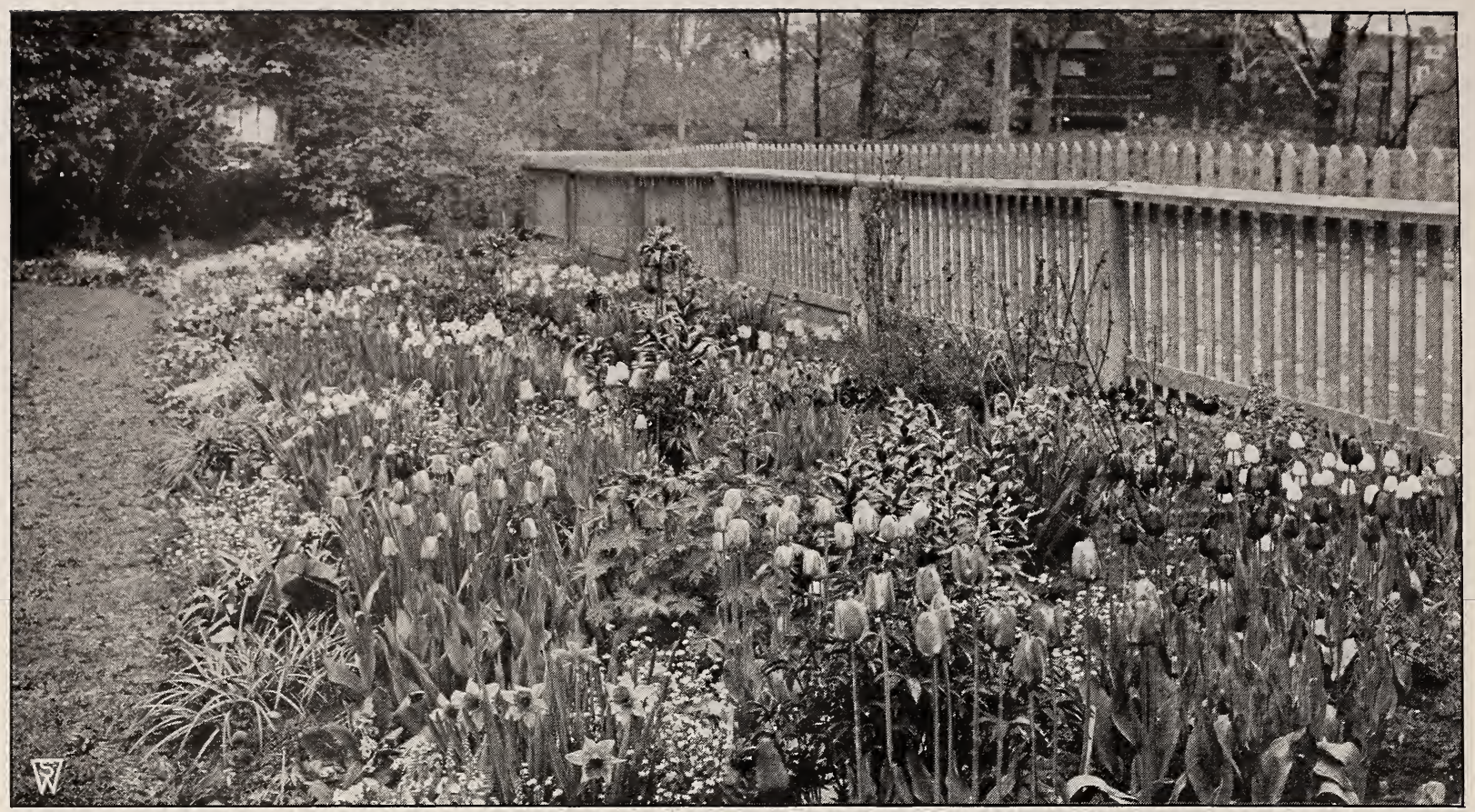

A hardy border illustrating the use of Darwin Tulips, planted in clumps throughout

\section{GIANT DARWIN TULIPS, May-Flowering}

For the herbaceous border, massed in clumps along the edge of shrubbery, or as cut-flowers for vases, these are conceded to be the superior of all the Tulips

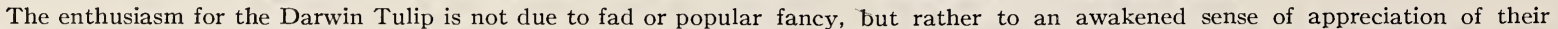

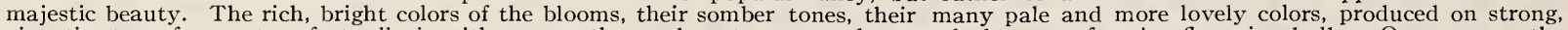

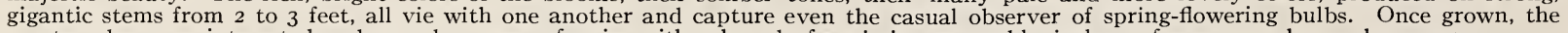

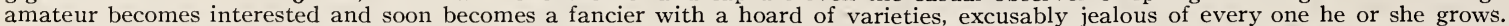

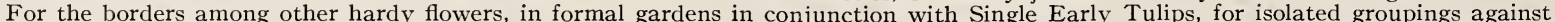

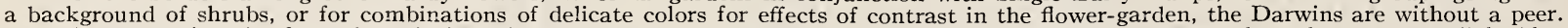

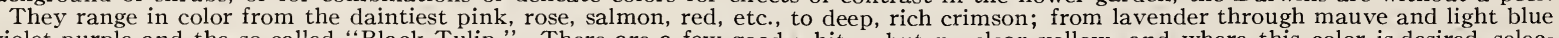

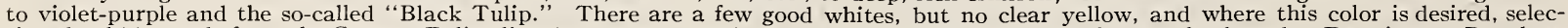

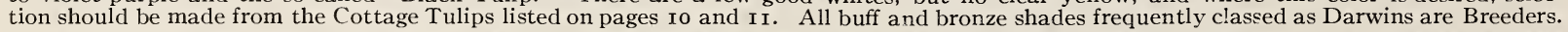

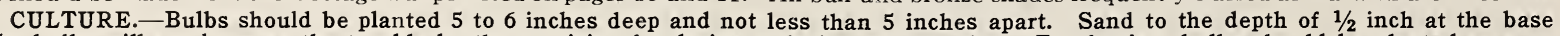

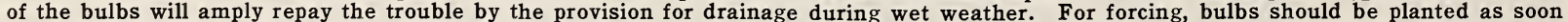

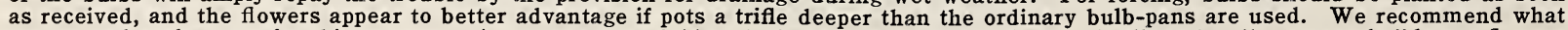

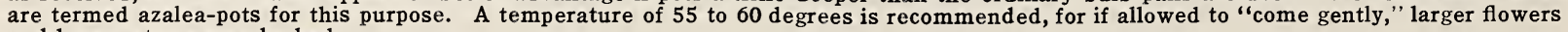
and longer stems may be had.

Afterglow. Deep, rosy orange, with sal- Doz. Ioo r,000 petals; inside deep orange at edges of base. A sport of Baronne de la Tonnaye, which is of remarkable interest because it is the first instance of a Darwin sporting to the Breeder tones. A showy Tulip for out-

doors. Height 26 inches...............

Anton Roozen. Vivid rose-pink, edged base marked blue, a slightly darker shade than Baronne de la Tonnaye. Large, cupshaped flower of great beauty. Height 28 inches.

Aphrodite. Clear, silvery rose-pink with round flower of exquisite color on a very tall, stiff stem. Height 34 inches............

Baronne de la Tonnaye. A long beautiful flower; clear carmine-rose at the midrib, base toning off to soft pink at the edges; white, tinged blue. Excellent for early March forcing and just as fine for outdoor beds, where it keeps up a splendid show for a long time. Height 26 inches.

Bartigon. Fiery crimson, a very showy $\$ 2$ oo $\$$ I 5 oo 26 inches variety with white base. Height
Bleu Celeste. A Tulip of wonderful is a bright violet-purple, white base tinged blue. Height 30 inches.

Carl Becker. Pale rosy violet, with rose Splendid Darwin for outdoors; equally good for forcing, but paler in color. Height 32 inches.

Centenaire. Rich violet-rose, with a flower of perfect large blue center; immense border; excellent for forcing. Height 32 in. I 30 1o oo

City of Haarlem. Intense dark scarlet large steel-blue base and white halo; wonderful cup-shaped flower, with petals incurving slightly at the tips. One of the finest brilliant red Darwins. Height 27 inches. .

Clara Butt. Beautiful clear salmon-pink. us has the same distinctive and pleasing color. Height 22 inches.

Crepuscule. Lilac-white, with dark, rosy flower of good form and a very lovely color when grown indoors. Height 28 inches. .
$\$ 250 \$ 2000$

$85 \quad 6$ oo $\$ 58$ oo $50 \quad 2000$

$50 \quad 3 \quad 50 \quad 32$ oc I $00 \quad 8$ oo $\quad 78$ oo 


\section{Giant Darwin Tulips (May-Flowering), continued}

Dal Ongaro. Pale lavender-violet, in- Doz. roo r,000 shading off into side dark bluish violet, with pure white base and showy white mid-

rib. Height 28 inches................ \$I oo $\$ 8$ oo $\$ \$ 78$ oo

Dream. Large flower, perfect in form, on

a tall, strong stem; color rosy lilac and mauve, with claret-purple interior.

Height 24 inches................... Pale slaty

$70 \quad 5 \quad 00 \quad 48$ o0

mauve, with stripe of rosy heliotrope; inside pale lilac, with white base. Enormous, long

flower on a tall, stiff stem. Height 29 inches. 2 oo I5 00

Eclipse. A deep rich glowing blood-red.

Large flower of fine form; the

best of its color. Height 26 inches...... 2 oo I5 oo

Edmee (Beauty). A beautiful shade of

cherry-rose with a lighter border.

On the order of Baronne de la Tonnaye, but brighter in color. Height 25 inches..

Erguste. Soft violet, with a slight silvery of the best Darwins $f, r$ forcing, keeping its refined color splendidly. Height 26 inches.

Europe. Deep, fiery crimson, with white flower base. Stems of medium length; trasting well when the flower opens. Height

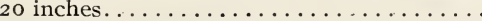

Euterpe. A beautiful shade Doz. Ioo ef mauve, edged

lilac, white center, with a

blue halo. A very refined color

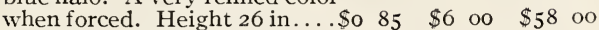

Farncombe Sanders.

A bright shade of scarlet, with a clear white base, contrasting well when the flower is fully open. A broad-petaled flower of large size. Fine for forcing or the border. Height 25 in.................

Faust. Satiny purple, with flower of fine form; a splendid Tulip. Height 30 inches ....

Flamingo. An even tone of A vale shell-pink. A very exquisitely colored Darwin, of refined coloring and form. Height 28 inches.

Giant. A flower of enormous Giant. size and of wonderful substance; a deep reddish purple in color, shaded violet with a white base. Height 30 in.

$200 \quad 1500$

Glow. The deepest shade of crimson - scarlet-a color of wonderful brilliance, not unlike that of the Oriental poppy. The flowers are of large size, borne on stems 20 inches long

Gryphus. Dark violet-purple, with a white base; a flower of splendid shape. A good border variety. Even more beautiful in color when forced. Height 26 in.

Gudin. Pale slaty lilac, edged pale lilac, flushed white; inside and blue halo long, handsome flower on a stiff stem. Height 27 inches.

Jubilee. Blue-purple, with a blue; a flower of large size and heavy substance. Height 29 inches.............. 2 o0 I5 00

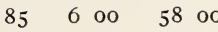
I, 000
King George V. Glowing salmonbright rose; inside brilliant orange-scarlet with blue base. A flower of intense color for outdoors. Height 25 inches............\$

King Harold. Intense $\mathrm{rub} y$-crimson, tall and of fine form; new and stately variety; very distinct. Height 24 inches ......

La Fiancee. Deep rose, shading to oldre and delicate pink at the of large size, and very effective when planted of large size, and very effective when planted
with mauve and dark lavender sorts. Height 30 inches.

$400 \quad 3000$

La Tristesse. Deep slaty blue, with in color; mediute hase, very distinct medium-sized flower. Height 26 a Tulipe Noire (The Black Tulip).

$\begin{array}{lllll}70 & 5 & 00 & 48 & 00\end{array}$

to the so-called "Black Tulip." Deep maroon-black, which has a velvety sheen in the sunlight. Height 25 inches.

$70 \quad 500 \quad 48 \quad 00$

Le Notre. Beautiful shade of bright Used for Exhibition purposes on account of the very large size of the flower and its

$70 \quad 5$ oo 48 oo $\quad$ strong stem. Height 26 inches........... . I 25 10 oo 98 oo

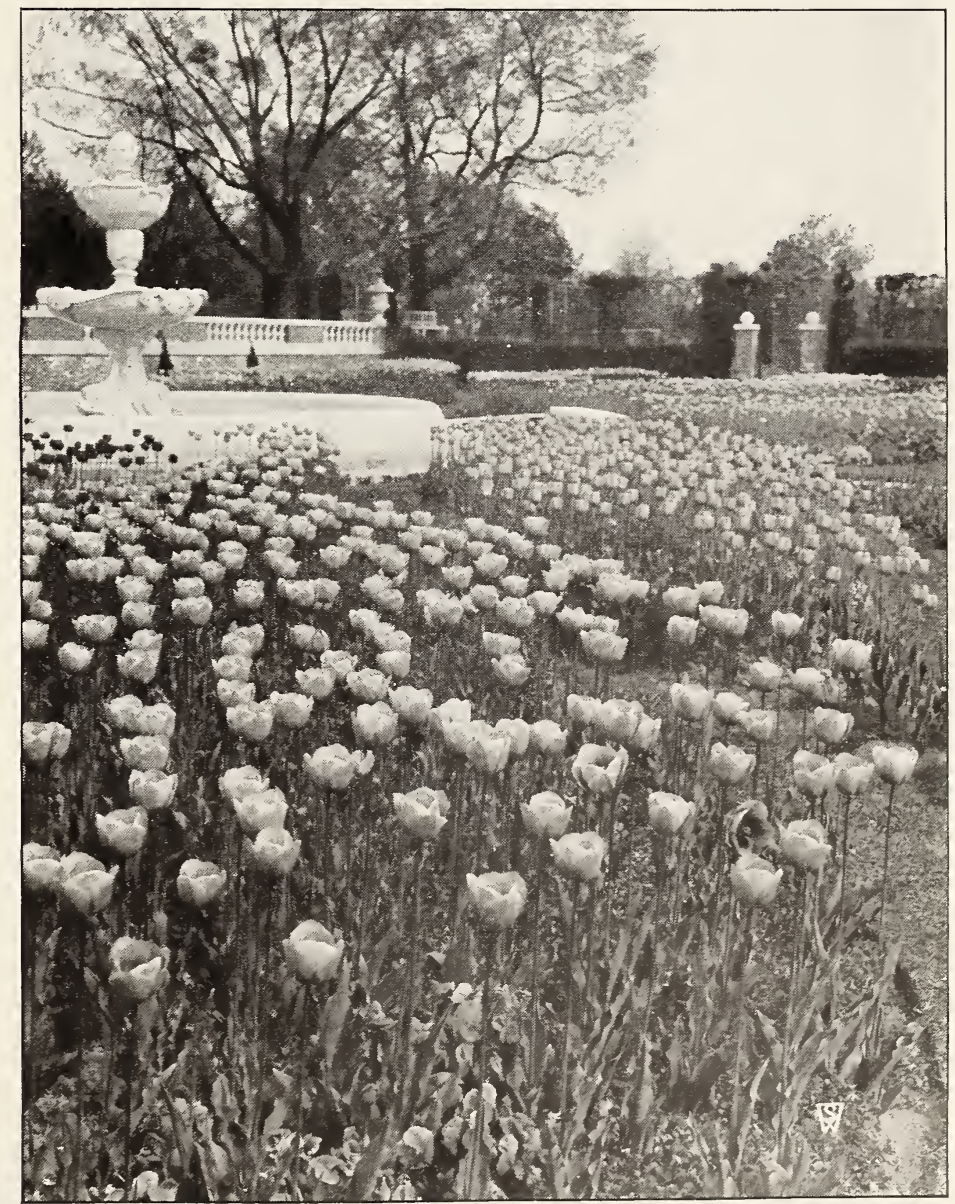

A Dutch Bulb Garden-Darwin Tulips, one variety to each of the various and pleasingly shaped beds 


\section{Giant Darwin Tulips (May-Flowering), continued}

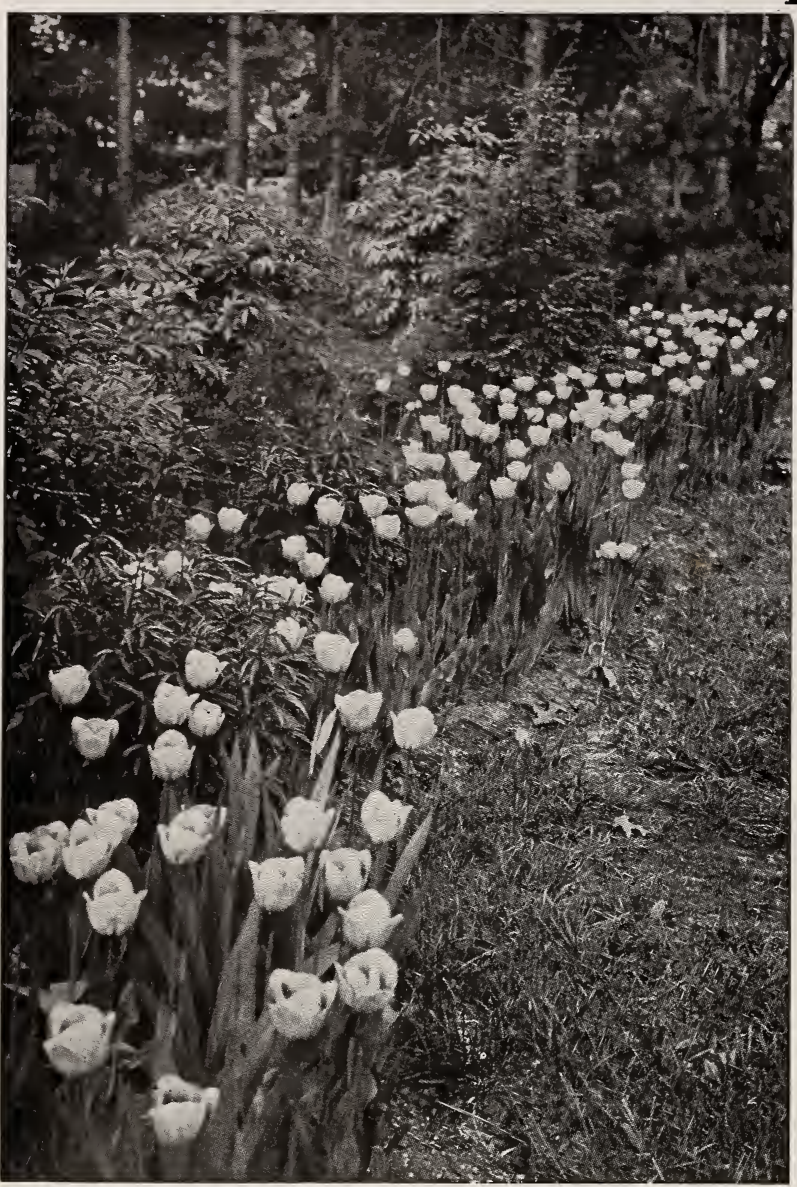

Darwin Tulip, Rev. Ewbank, planted along the shrubbery border

Louise de la Valliere. Brilliant Doz. 100 r,000 with pale blue base starred white. A very

clear and beautiful color. Height 24 inches. $\$ 2$ oo $\$$ I $_{5}$ oo

Mme. Barrois. Dull lilac-rose, with changes with age to pale flesh-white; bluish base. A fine new Darwin of very attractive tone. Height 25 inches.

$350 \quad 25$ oo

Madame Krelage. Bright rosy lilac, margin. A good forcing variety and excellent for the border as well. Height 28 in.

Madame Raven. Dark cherry-rose, base, blue halo; me edged rosy white; white fect shape. A variety of the same general character as Edmee or Mme. Krelage, but with sharper contrast between the dark rose and almost clear white edge. Height 25 in.

Marconi. Deep purple when the flower first opens, gradually changing to ashy purple as the flower ages; pure white base. Height 27 inches

Margaret. Pale rose ground, faintly marked blue flushed white, center white, globular in shape, borne on a strong stem. Splendid for forcing. Height 22 inches.

Massachusetts. A long and beautiful tower; clear carminerose at the midrib, toning off to soft pink at the edges, the inside of the white base delicately tinged blue. Height 26 inches.

Massenet, An exquisite shade of pale Doz. creamy white acquisition to any collection however rare Height 30 inches. ..............\$I $25 \$$ I0 oo

Matchless (Roi d'Islande). Soft old-rose in a narrow white border; inside soft violet-rose with a blue base. A very beautiful soft color and one that forces splendidly. Height 26 inches ........... I $00 \quad 7$ oo $\$ 68$ oo

Mauve Clair. Soft lilac-mauve, slightly petals; inside lilac-mauve, with white base. Height 26 inches.

$80 \quad 5 \quad 50 \quad 52$ oo

Melicette. A beautiful pure lavender, the edges, with a beautiful blue base; quite the purest lavender Darwin. A flower of large size. Height 26 inches. ............

Mrs. Potter Palmer. Bright purplish white; a large flower. Very attractive for border planting. Height 28 inches........

Mystery. An unusual flower of a deep variety used for exhibition purposes on account of its size. Height 30 inches........

Nauticas. Dark rose, center clear violet, Excellent shaded bronze; large flower. late forcing. Height 30 inches.

Olifant. Smoky lavender of very silvery lifant. character, with distinct blue flush on outer petals; pure white base; huge flowers on very tall stems. A very early variety. Height 32 inches..........

Painted Lady. A pale creamy white, heliotrope, gradually becoming almost pure white as the flower ages. A very good forcing variety. Height 27 inches

Pensee Amere. Slaty violet, with a petals of rosy lilac, white base. Not a large flower but of exquisite shape. Height 26 in.

Petrus Hondius. Bright carmine-rose, - with a dull blue base d white. An unually brilliant variety. Height 28 inches ............... Phipe de Commines. of dark, polished mahogany color, with a purple base. One of the best of the less expensive sorts in this color. Height 24 inches .

Pride of Haarlem. Magnificently immense size, brilliant, deep rose, shaded scarlet, with light blue base. This variety, perhaps the most widely known for its stately habit and glorious color, is unsurpassed for border planting. Height 36 inches.

I $25 \quad 8$ o0 78 OO

$70 \quad 500$

48 oo

$500 \quad 4000$

$65 \quad 450 \quad 42$ oo

$500 \quad 4000$

Prince of the Netherlands. Lively

$70 \quad 5$ oo $\quad \$ 48$ oo of cerise-scarlet, edged
base. Height $3 \mathrm{I}$ inches.

Princess Elizabeth (Julie Vinot). Beaurincess Elizabeth (Jiful clear deep pink, changing with age to rose-pink; white base. Large flower of perfect shape, quite like a rose when first open. Splendid for the border or for forcing. Height 26 inches..

Princess Mary. Bright carmine-rose with margin of rosepink; inside clear carmine-rose with blue base and white halo; huge flower on a splendid stem. One of the finest of the new Darwins. Height 28 inches ..............

Professor Rauwenhoff. B right beautiful blue base; very large flower of wonderful substance. Height 24 inches... Psyche. Old-rose, edged white, inside grand variety for February forcing. Height 26 inches

\section{10}

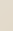

$80 \quad 5 \quad 50 \quad 52 \quad 00$

$60 \quad 400 \quad 3800$

I $20 \quad 9$ oo 88 o0

I 10 8 o0 78 oо

30010000

I $00 \quad 7$ oo 68 oo

$70 \quad 500 \quad 48$ oo 


\section{Giant Darwin Tulips (May-Flowering), continued}

Purple Perfection. The color of the glossy purple, large in size, and of wonderful substance. A splendid variety in the border on account of its pronounced color and size; grows to the height of 26 inches.........\$ \$o $85 \quad \$ 6$ oo $\$ 58$ oo

$\underline{\text { Raphael. Deep maroon-purple of rich }}$ white. Very tall, large flower of sturdy character. The best reddish purple. Height

$\begin{array}{r}30 \text { inches } \ldots \ldots \ldots \ldots \ldots \ldots \ldots \ldots \ldots \ldots \\ \text { Remembrance. Pale lilac, general tone } \\ \hline\end{array}$ Quite distinct; large flower. Height 25 in.

Reverend Ewbank. An exquisite ender-violet, slightly shade of soft lavvariety of great merit on account of its lovely color, borne on stems 23 inches long .......

Ronald Gunn. Bright shade of violet, with a conspicuous white base. A flower of splendid shape and, like most varieties near this shade, even more exquisite when grown in pots. Height 26 inches ................

Sir Trevor Lawrence. Violet-maflush of ashy purple; inside violet-maroon with white base; very large, cup-shaped flower, on tall stem. Splendid in every respect. Height 33 inches . ..............
Sophrosyne. Soft rosy lilac, edged sil-

Sophrosyne. very white; inside deep rose, with striking dull blue base. A large flower of very delicate beauty. Height 29 inches.

Suzon. Center of petals buff-rose, shading base, delicately marked blue. A strong grower of fine stately habit. Height 25 in.

$\mathrm{I}, \mathrm{O00}$

$65450 \quad 42$ oo

I Iо 8 0о 78 00

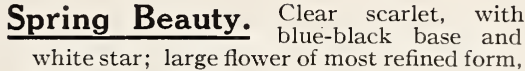
and the handsomest of all scarlet-red Tulips.

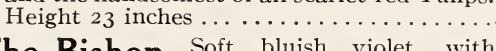

The Bishop. Soft bluish violet, with with white base; a long flower of very artistic color. Height 28 inches .... . .....

Valentin. A magnificent Tulip of large violet with a blue base. Height 22 inches. I Io 8 oо 78 oo

Venus. Pure silvery rose; a flower of exinches long c......................

Village Maid. Soft rose with whitish flower on a tall stem. Height 30 inches.... 2 oo I $_{5}$ oo

White Queen. A splendid white variis pale rose but quickly turns white-a truly exquisite color. Height 24 inches . .......

William Copeland. Uniform lilacthat was greatly admired in our exhibit of bulbs grow1 in pots at the New York Flower Show this year. May be forced as early and as easily as the early Tulips. The color, when grown indoors, becomes a most beautiful lavender. Height 24 inches...

William Pitt. Very dark crimson, with outer petals. Of great size and beauty. Height 24 inches

Zulu. Deep, velvety purple-black; large, form. Fine for border or forcing. Height 27 inches $\begin{array}{llllll}\$ \text { I } & 20 & \$ 9 & \text { oo } & \$ 88 & \text { oo }\end{array}$ $400 \quad 3000$

oo 7 oo 68 oo

$85 \quad 6$ oo 58 oo
$85 \quad 600 \quad 5800$

Superb Prize Mixture. The wonderful interest in these splendid Tulips has brought out a great many varieties too numerous Superb Prize Mixture. for listing, except those considered the best. In addition to some of the varieties listed above, our named sorts. $60 \mathrm{cts}$. per doz., $\$ 4$ per $100, \$ 35$ per 1,000 .

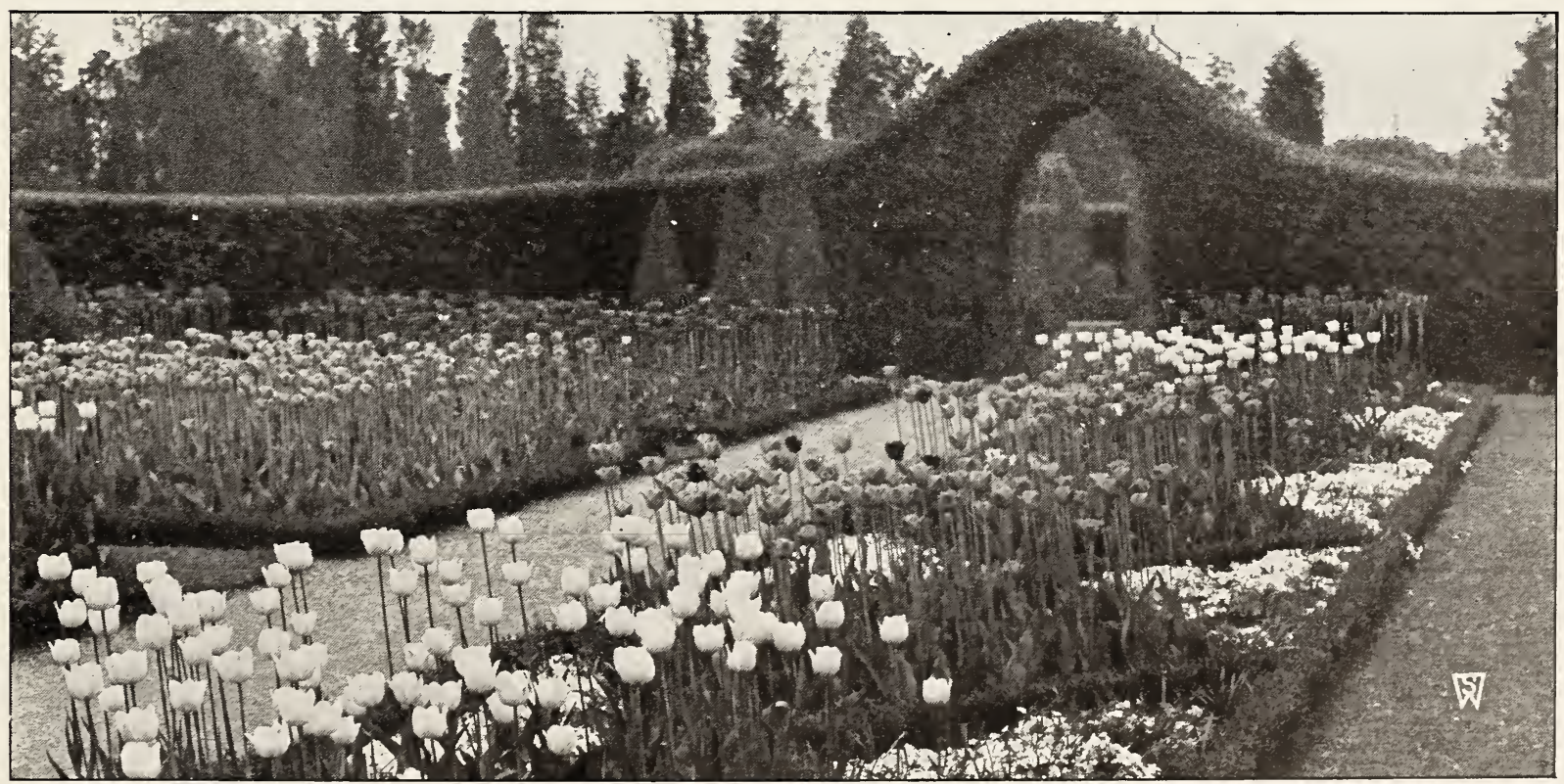

A well-designed and pleasing display of Darwin Tulips 


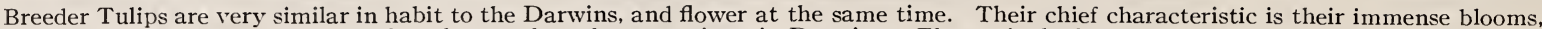

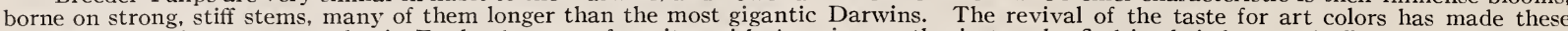

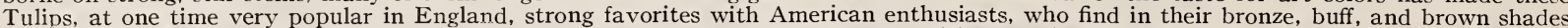

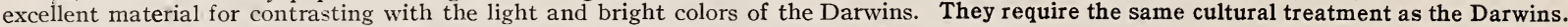

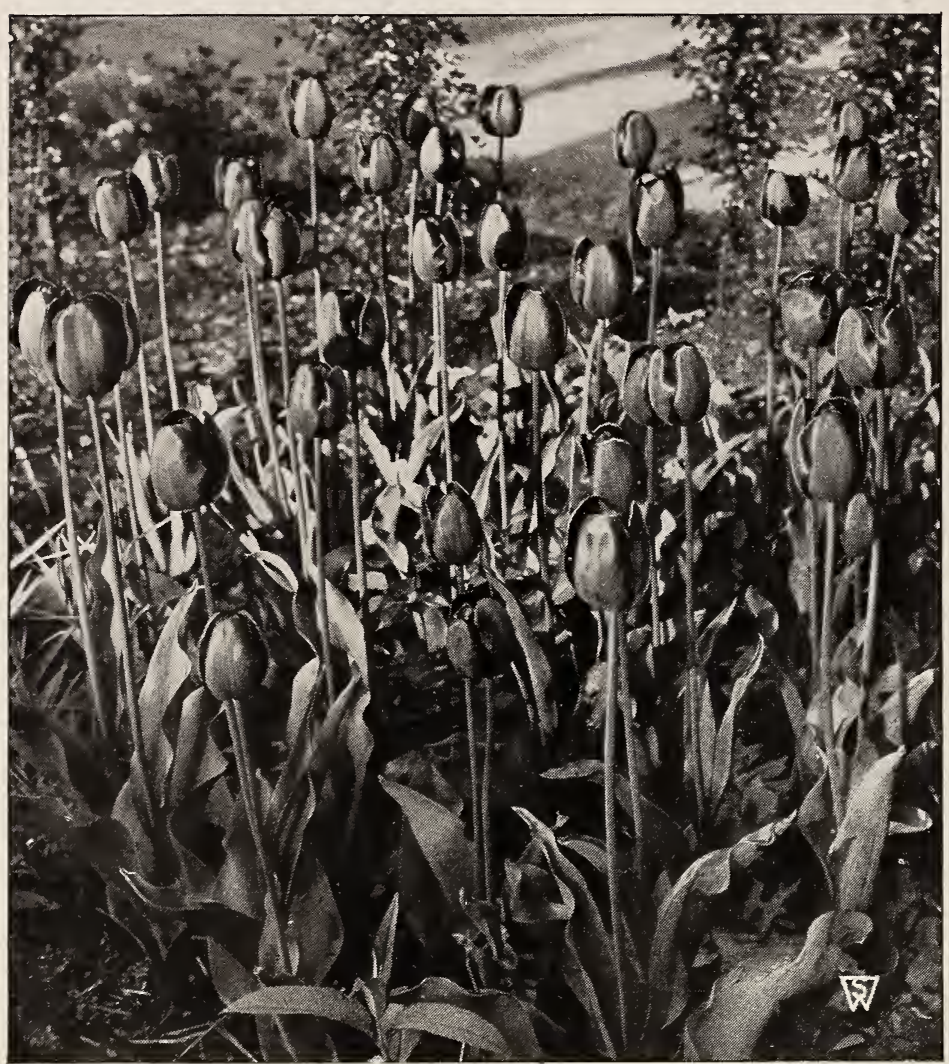

Dutch Breeder Tulips photographed late in the afternoon when their artistic color lends a distinctive and refined atmosphere to the flower border

Abd-el-Kader. Dull bronze-yellow, shading to light bronze at green base; good-sized flower. Height 26 inches. $\mathbf{\$ 2}$ per doz. $\$ 15$ per 100 .

A pricot. Dull, bronzy buff, shaded deep apricot, base olive-green. Apricot. A splendid border variety, frequently having an extra number of petals. Height 25 inches. 85 cts. per doz., $\$ 6$ per 100 $\$ 58$ per 1,000 .

Bacchus. Dark violet-blue, the outside of the petals having a approach to dark blue in late Tulips. Still high in price on account of scarcity. Height 28 inches. \$2 per doz., \$15 per 100.

Bronze Queen. Soft golden bronze; large flower of sturdy Q habit. A very exquisite color when forced and splendid for the border. Height 28 inches. 85 cts. per doz., $\$ 6$ per $100, \$ 58$ per 1,000 .

Cardinal Manning. A splendid shade of rosy violet, with large-sized flower of fine a slight edge of bronze. A splendid $\$ 5.50$ per $100, \$ 52$ per 1,000 .

Copernicus. Light coffee-brown, with slight flush of bronzy large flower on sturdy stem. A fine example of the brown Breeders. Height 27 inches. \$1.70 per doz., \$13 per 100.

Coridion. Clear yellow, with a faint suffusion of lilac; a flower Height 24 inches, $\$ 1.50$ per doz., $\$ 12$ per 100 per 1,000 . per 100.
Dom Pedro. Coffee-brown, shaded maroon, inside fragrant. Height rich mahogany; large flower; very 100.

Dryad. Lilac-old-rose, margined bronzy yellow, inside with bright apple-green base. A very beautiful Breeder of which we have only a few bulbs to offer. Height 22 inches. \$3.50 per doz., \$25 per 100.

Fairy. Reddish mahogany, with bronze shading; an extra-large flower of artistic character. Splendid in borders or for late forcing. Height 24 inches. $\$ 1.30$ per doz., $\$ 10$ per 100.

Garibaldi. One of the finest Breeders as yet introduced. Pale lilac-bronze, with a broad primrose-yellow margin. A long and graceful flower. Height 3I inches. \$3.50 per doz., \$25 per 100 .

General Ney. Dull old-gold with olive base; $\$ 1$ per doz., $\$ 7$ per $100, \$ 68$ per 1,000 .

Godet Parfait. Dark blue-purple, with white base of striking color. One of the best Breeders for the border. Height 30 inches. $\$ 1.50$ per doz., $\$ 10$ per 100.

Golden Bronze, Light brownish yellow, with Golden Bronze. flush of heliotrope; inside rich mahogany-brown, rich yellow base. A large, wellformed flower of attractive appearance. Height 26 inches. $\$ 1.10$ per doz., $\$ 8$ per 100, $\$ 78$ per 1,000 .

Goldfinch. Elegantly formed, large, pointed flower. mahogany brown, yellow base, marked olive. Height 30 inches. $\$ 2.50$ per doz., $\$ 20$ per 100.

Heloise. A beautiful shade of dark brown, shaded old-rose; yellow base, marked olive-green. Large-sized flower of wonderful color and very prettily reflexed petals. Height 28 inches. $\$ 3.50$ per doz., \$25 per 100 .

Indian Chief. Reddish mahogany flushed purple, edged warm brown with age; and most artistic shape, carried on a very tall stem. Height 33 inches. 75 cts. each, $\$ 7.50$ per doz.

Jaune d'Oeuf. Ruddy apricot, inside soft yellow, with black 2 inches. 80 cts. per doz., $\$ 5.50$ per $100, \$ 52$ per 1,000 .

James Watt. A new Breeder of exquisite form and coloring. Deep slaty violet, flushed bronze; inside dar mahogany, shaded brown, fine green 16 inches. $\$ 4$ per doz., $\$ 30$ per 100 .

Jules Favre. Beautiful shade of deep bronze, purple flush shaped flower.

Le Mogol. Pale lavender-mauve, flushed white; inside deep Le Mogol. mauve-lilac, with beautiful white base and blue halo A flower of medium size but of exquisite color. Height 26 inches. $\$ 1.10$ per doz., $\$ 8$ per 100 .

Lord Cochrane. Dark brown, with narrow margin of bright bronze-yellow; inside warm brown with yellow base. A striking. Breeder because of the clear shade of yellow on the margin. Height 28 inches. $\$ 1.30$ per doz., $\$ 10$

Louis XIV. An even tone of dark purple, with a broad margin Louis XIV. of golden bronze; a very large flower of wonderful substance; green-black base starred yellow. A very scarce variety and one that instantly meets with favor when grown. Height 30 inches. $\$ 2.50$ per doz., $\$ 20$ per 100 . 


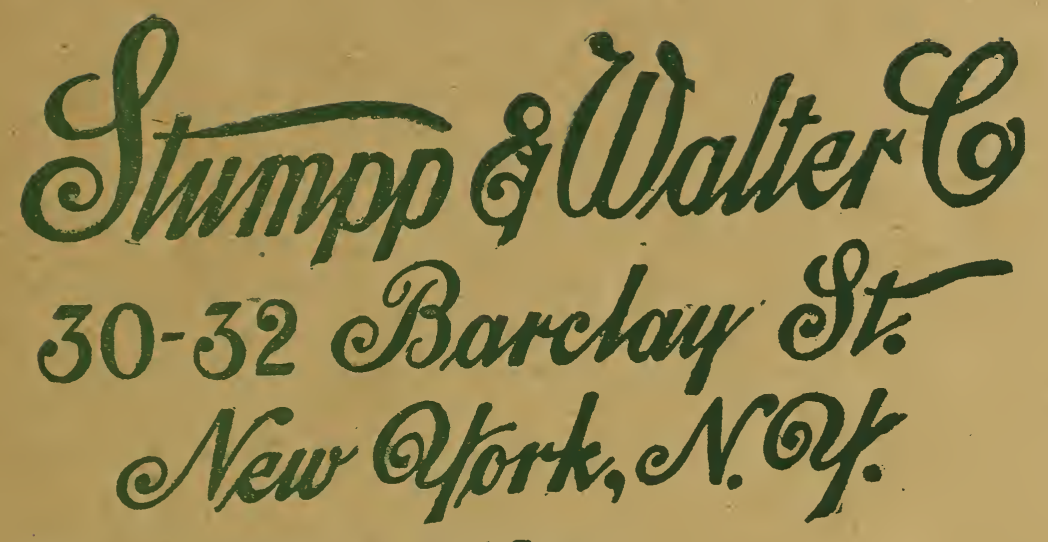

P. O. Box 165, City Hall Station. 


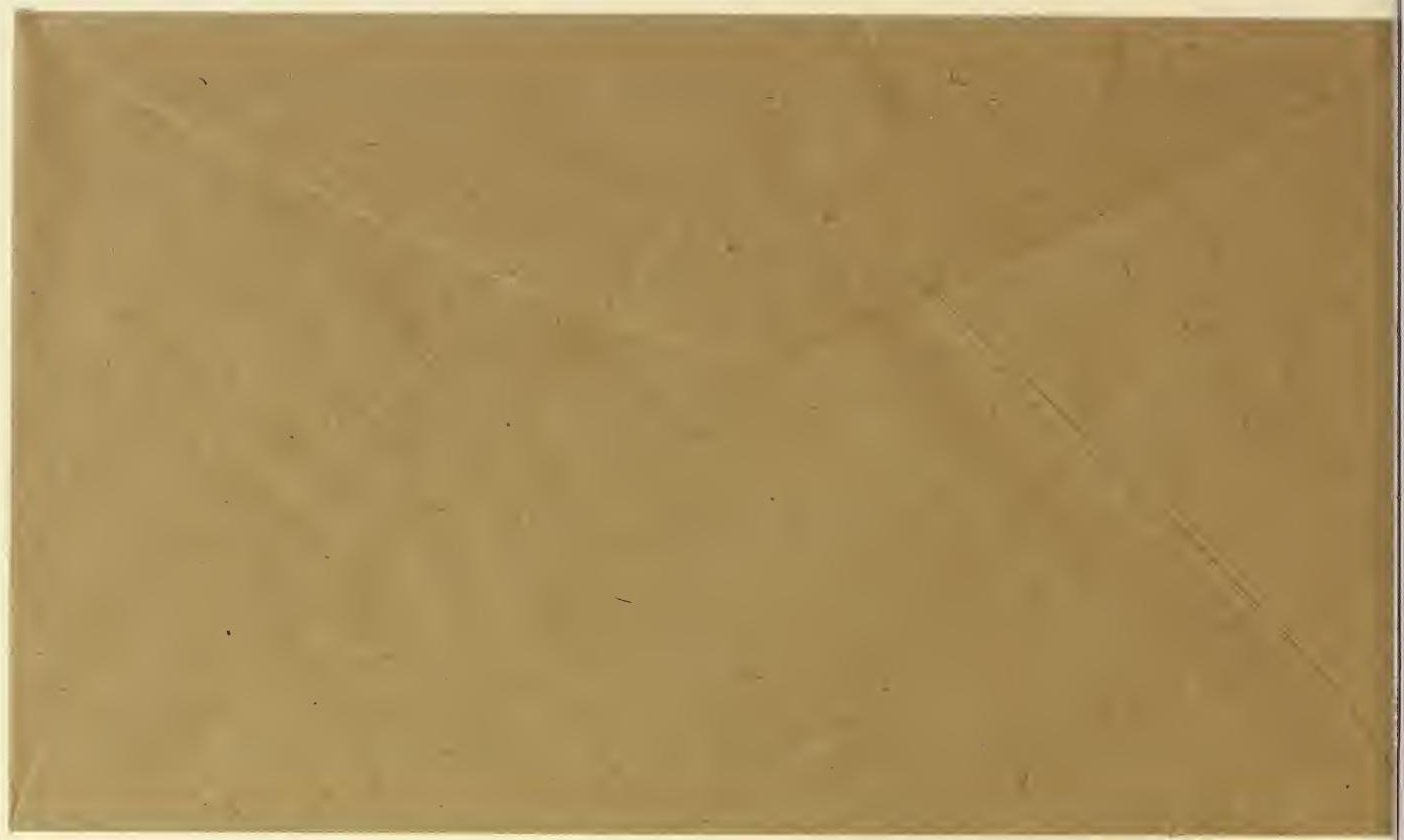




\section{Dutch Breeder Tulips (May-Flowering), continued}

Lucifer. Clear orange, with a rosy flush and olive base, with 24 inches. \$2 per doz., \$15 per 100.

Madame Lethierry. Dark crushed strawberry, edged and dium size, a very distinct formed salmon-a unique color; megrown in partial shade. Height 26 inches. $\$ 1$ per doz., \$7 per $100, \$ 68$ per 1,000 .

Madras. Golden bronze, with dull heliotrope stripe on the outer Madras. petals, yellow base starred green. A long, good-sized flower. Height 26 inches. \$1 per doz., \$7 per 100, \$68 per 1,000. Marechal Victor. Pale lavender-violet, with broad edge of buff shaded bronze; in ide violet, faintly flushed mahogany with beautiful green base - a wonderful color combination which we have seen in no other Tulip. A large flower of open graceful form. Height 28 inches. 40 cts. each, $\$ 4$ per doz.

Marie Louise. Old-rose, flushed orange-salmon, with purplish for bloom and olive base. A very beautiful Tulip $100, \$ 58$ per 1,000 .

Moody. Dull lilac-purple, with narrow edge of amber-brown, inside maroon-purple, with blue-purple midrib, and

bright yellow base starred olive and white. Height 23 inches. $\$ 1.20$ per doz., $\$ 9$ per $100, \$ 88$ per 1,000 .

Newton. Dark purple, with plum bloom on outer petals. A - flower of the same tone as Darwin Jubilee, but not $\$ 10$ per doz.

Old Times. Dull garnet, edged primrose-yellow, with greenish . A showy Breeder of English origin. Height 24 inches. $\$ 2$ per doz., $\$ 15$ per 100.

Pink Pearl. A new Breeder and quite the finest of its color. The hite outside of the flower is a lilac-pink, inside rose, base. A magnificent, large, egg-shaped flower. Height 26 inches. \$4.50 per doz., \$35 per 100.

Plutarchus. Bronzy yellow, with a flush of heliotrope in the center of the petals; a flower of wonderful substance and splendid form. Height 26 inches. $\$ 1.20$ per doz., \$9 per $100, \$ 88$ per 1,000 .

Prince of Orange. Dark terra-cotta-brown, shaded yellow,

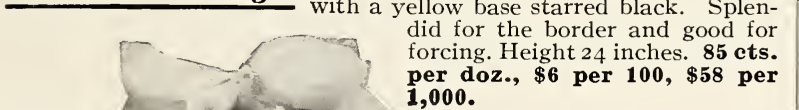

Prince Albert. Golden brown, with purple flush through center Height 32 inches. $\$ 2$ per doz., $\$ 15$ per 100.

Prince of Wales. Warm maroon-brown; inside coppery Long flower of flat, brown, with black base, starred yellow. Breeders. Height 28 inches. \$2.50 per doz., \$20 per 100.

Roi Soleil. This new Breeder Tulip is a combination of shadesrich dark violet, flamed with bronze. A magnificent, large flower borne on strong stems. Height 28 inches. $\$ 4.50$ per doz., \$35 per 100.

Sabrina. Coffee-brown, edged light brown; inside mahoganybrown, with yellow base. A medium-sized flower of value where a less costly Tulip is wanted in this shade. Height 23 inches. $\$ 1$ per doz., $\$ 7.50$ per $100, \$ 72$ per 1,000 .

Salomon. Silvery lilac, flushed buff when opening, inside slightly formed flower, carried on a graceful stem. Height 30 inches. $\$ 2$ per doz., \$15 per 100.

Socrates. Deep rosy violet, with dull blue base; large flower of stately habit, often having an extra number of petals. inches. $\$ 1.20$ per doz., $\$ 9$ per $100, \$ 88$ per 1,000 .

St. James. Dark rosy lilac, edged bronzy tan, with coppery rose . James. flush at tips of petals; inside ruddy mahogany, edged golden brown with yellow and green base. A large flower on tall stem. Height 28 inches. \$3 per doz., \$22 per 100 .

Turenne. Purplish brown, with a broad margin of soft yellow, Turenne. very large flower and on account of its unique coloring very attractive for group planting. Height 28 inches. \$1.20 per doz., $\$ 9$ per $100, \$ 88$ per 1,000 .

Velvet King. Deep, glossy purple-maroon, with a white base; bloom. A magnificent Tulip for the border or shrubbery and forms an effective contrast when planted with the light-colored Tulips. Height 28 inches. \$2 per doz., \$15 per 100 .

Vulcain. Reddish apricot, with broad margin of bright buffyellow, inside dark apricot edged yellow, with dark green base starred yellow. A flower of splendid form and in color
unlike any other Tulip. Height 25 in. $\mathbf{3 0 c}$. each, $\$ 3 \mathbf{~ p e r ~ d o z . ~}$

Wilberforce. Soft apricot, edged primrose-yellow, green base. Not a large flower, but very distinct. Height 32 inches. \$2 per doz., \$15 per 100 .

Yellow Perfection. Bright bronze-yellow, with an edge of fine form. Height 24 inches. 85 cts. per doz., $\$ 6$ per 100, $\$ 58$ per 1,000 . 


\section{STUMPP \& WALTER CO., 30 AND 32 BARCLAY ST., NEW YORK \\ Old English COTTAGE TULIPS, MAY-}

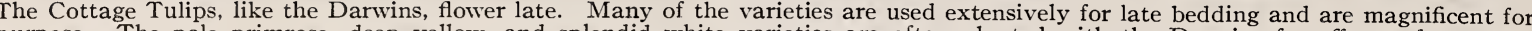

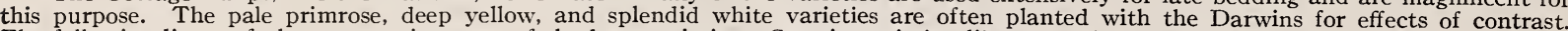

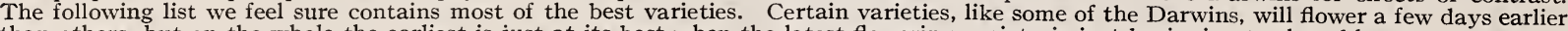
than others, but on the whole the earliest is just at its best when the latest-flowering variety is just beginning to show bloom.

Ambrosia. This beautiful new variety of Doz. Ioo $r, 000$ Ambrosia. Cottage Tulip contains a combination of shades-bronze with rosy lilac glow; inside of the large, well-shaped flower is a salmon-orange tone. Height 22 inches...\$2 $50 \quad \$ 20$ oo

Avis Kennicott. A rich, deep shade striking black base and anthers. One of the best of the newer varieties. Height 25 in... I Io $\quad 800 \quad \$ 7800$

Daybreak. Dull mauve, with a margin of base. A very beautiful variety. Height I 7 inches.................... I oo $700 \quad 6800$

Dido. A large, well-formed flower of rich orange-rose tone, with margin of bright orange-yellow, inside bright orange with yellow base. Height 24 inches....... $250 \quad 2000$

\section{(1)}

COTTAGE TULIPS-(1) Inglescombe Pink, (2) Inglescombe Yellow, (3) Gesneriana spathulata or major, (4) Picotee
Fairy Queen. Beautiful soft rosy lilac, Doz. Iоo

$\mathbf{x}, 000$ gined amber-yellow. A variety that should be included in every collection on account of its unique and lovely color. Height 20

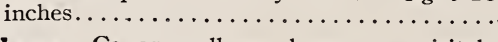

Flava. Canary-yellow, large, exquisitely Iava. formed flower with magnificent lasting qualities. Height 25 inches........ 2 oo I5 oo

Gesneriana ixioides. Soft primroseyellow, w i t flower of medium size, attractive for the contrast between the base and the rest of the flower. Height 22 in.

Gesneriana lutea. One of the best of $85 \quad 6 \quad 00 \quad 58$ oo Gesneriana family. A bedder of now passed qualities, with perfect-shaped flowers of purest golden yellow, on strong stems holding the flowers perfectly erect. Height 24 in

Gesneriana spathulata, or major.

The beautiful curved flowers are brilliant scarlet, with a bluish black center, on tall stems. Height 18 inches...............

Gold Dust. Chrome-yellow, with faint edge of dull orange-red; large flower with slightly reflexing petals. A good yellow of this type, as the red edge does not suffuse the whole flower with age. Height 23 inches....

Grenadier. Brilliant orange-red. A new Tulip of great beauty. Flowers long, borne on very graceful stems. Height, 24 inches.....................

Hammer Hales. Golden brown. flushed apricot. edged bronze-yellow, with a yellow base. Height 24 inches.............. 2 oo $\mathrm{I}_{5} 00$

Inglescombe Pink (S a 1 m o n Beautiful soft rosy pink, slightly flushed salmon; large, globular flower of excellent form. Adapted for borders or 1 a t e forcing. Height 22 inches.......... $65 \quad 450 \quad 4200$ Inglescombe Scarlet. A very charming variety of true Cottage type; intense scarlet. Should not be planted with Inglescombe Pink or Yellow, as they are fully 6 inches taller and resemble the Darwin type. Height $I 6$ inches.......... Inglescombe Yellow. A beauriety. Size, form and height greatly resemble the Darwins, so much so that it is frequently called the "Yellow Darwin," a fitting title. Height 22 inches....

Innocence. Pure white, with yellow Innocence. base; a flower of fine form on a stiff stem. Excellent for border and a good variety for pots if forced gently. Height 20 inches..................

John Ruskin. Salmon-rose, edged soft rosy lilac-a beautiful combination of colors; large flower of fine shape on a graceful stem. Height $\mathrm{I} 6$ inches .................. 502000

$\begin{array}{lllll}60 & 400 & 38 & 00\end{array}$

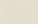

(n)

$65 \quad 4 \quad 50 \quad 42 \quad 00$
$00 \quad 3800$
0 


\section{Old English Cottage Tulips (May-Flowering), continued}

Kingfisher. Creamy yellow ground, with Doz. Iо I,00

larly striped and feathered maroon and violet; blue-green base; large flower on sturdy stem. A most interesting variety well named because of the combination of unusual colors. Height I8 inches........\$3 $50 \$ 25$ oo

La Merveille. Very large, s w e e $t$ mon-rose, overlaid with orange-red. A grand border variety. Height 20 inches.........

Leda. This variety has a very lovely warm $65 \quad 4 \quad 50 \quad \$ 42$ oo som inside, splendid outside, peach-blosbase. The flowers are large in size and are borne on strong stems.................

Miss Willmott. A pale primrose-yellow of true Cottage form. In good demand on account of its delicate color.
Height 8 inches.........................

Moonlight. Bright canary-yellow; splenshape, outer petals slightly reflexed at the tips. An excellent yellow for combination with the Darwin varieties. Height 22 in.

Mrs. Kerrell. Beautiful light rose with rente a delicate amber tinge, center white, bordered electric blue. A new variety of very refined coloring and shape and destined to win a place for itself among discriminating flower-lovers. Height I8 in.. 25020 oo

Mrs. Moon (Fulgens lutea maxima). flowers of good substance, slightly reflexing. flowers of good substance, slightly reflexing.

Orange King. Beautiful deep orange, orange-scarlet with a yellow center. Height

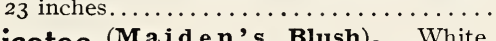

$\underline{\text { Picotee (Maiden's Blush), White, }}$ suffusing the whole flower as it ages; medium-sized flower, reflexing. A grand Tulip for the border. The sight of a large bed planted wholly to this variety is one that will not easily be forgotten. Height $20 \mathrm{in.}$.

Pluto. Self-colored rose-pink; good-sized 1uto. flower of beautiful color and shape, with white base and blue star; best seen when planted by itself. Height 25 inches. .

Pride of Inglescombe. White, broadly mine-rose, white base starred blue. A long, and exquisitely-shaped Tulip somewhat like Picotee, but brighter in color. Very attractive planted in mass. Height 23 inches....

Quaintness. Old-gold, flushed deep rose; I 50 I 2 OO $65 \quad 4 \quad 50 \quad 4200$ $70 \quad 500 \quad 48$ o0 hogany. Immense flower with very long petals. Height 24 inches...............

Striped Beauty. Silvery rose, blotched carmine and white; large, showy flower on a graceful stem. Height I 8 inches............

The Fawn. The coloring is a unique changing to blush-rose. Height 20 inches...

The Lizard. Deep blood-red, with purfeathered yellow and white A striped and most unusual markings. Height 24 inches.

Twilight. Dull violet-mauve, edged warm willown, irregularly striped and flamed dark violet; white base with blue halo, and striking white midrib; long, goodsized flower. Height 23 inches...........

Union Jack. Light violet, feathered purwhite; blue base; large flower. A very striking variety. Height 20 inches........

Vitellina Pale yellow, becoming creamy flower of great substance and beauty; sweetscented. Excellent forcer...

I 00700

856 oо $\quad 5^{8}$ oo

$60 \quad 400 \quad 3800$

$85 \quad 6$ oо 58 oо $200 \quad 1500$ I 007 oo 6800 $70 \quad 5$ oo 48 oo

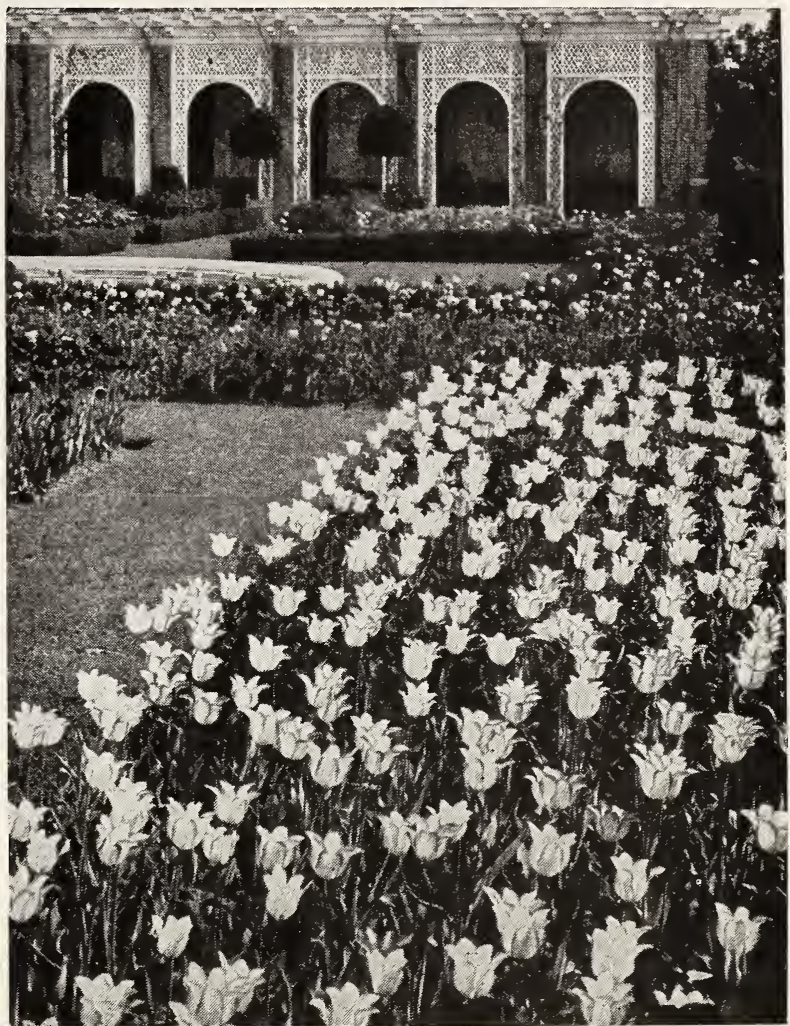

A well-thought-out arrangement of Darwin and Breeder Tulips, with the Cottage Tulip Picotee in the foreground

Walter T. Ware. Deep golden yellow, Doz. Iоo I,00о richest color among Late Tulips; broad,

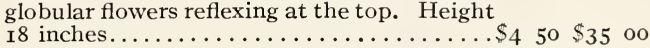

Yellow Picotee. Beautiful canary-yelrose. A yellow counterpart to the wellknown variety Picotee. A showy bedder.

Height 20 inches. ...

$85 \quad 6 \quad 00 \quad \$ 58$ oo

Superb Mixture. A select assortment, covering almost every conceivable color and shade. Those who have not grown these Tulips, and desire a mixture for trial purposes, can depend on getting every color that obtains in this beautiful class of Tulips. $50 \mathrm{cts}$. per doz., $\$ 4$ per $100, \$ 35$ per 1,000 .

\section{BOTANICAL TULIPS}

CARINTA RUBRA. Rich deep crimson, center of petal striped green. A very unusual Tulip in color and excellent for border planting where evergreens are used as a background. Height 15 inches. $\$ 1$ per doz., \$7 per 100, $\$ 68$ per 1000 .

CLUSIANA. The "Little Lady" Tulip. A lovely little variety from Asia Minor. Grows about 8 inches high, flowers as large as a crocus. Outer petals cherry-red, inner petals white with violet base. Should be planted 8 to 9 inches deep in light soils. \$1 per doz., $\$ 8$ per 100, $\$ 78$ per 1,000 .

KAUFMANNIANA. One of the earliest of all the Tulips to come in flower. Creamy white, tinged rosy red, the markings varying. The flowers are very attractive, large in size, with petals reflexing. Blooms early in April. \$1.30 per doz., \$10 per 100 .

MARJOLETTI. Splendid for rock-gardens in a sheltered place. May be forced in pots also. Blooms outdoors during late April. $\$ 1$ per doz., $\$ 7$ per $100, \$ 68$ per 1,000 . 


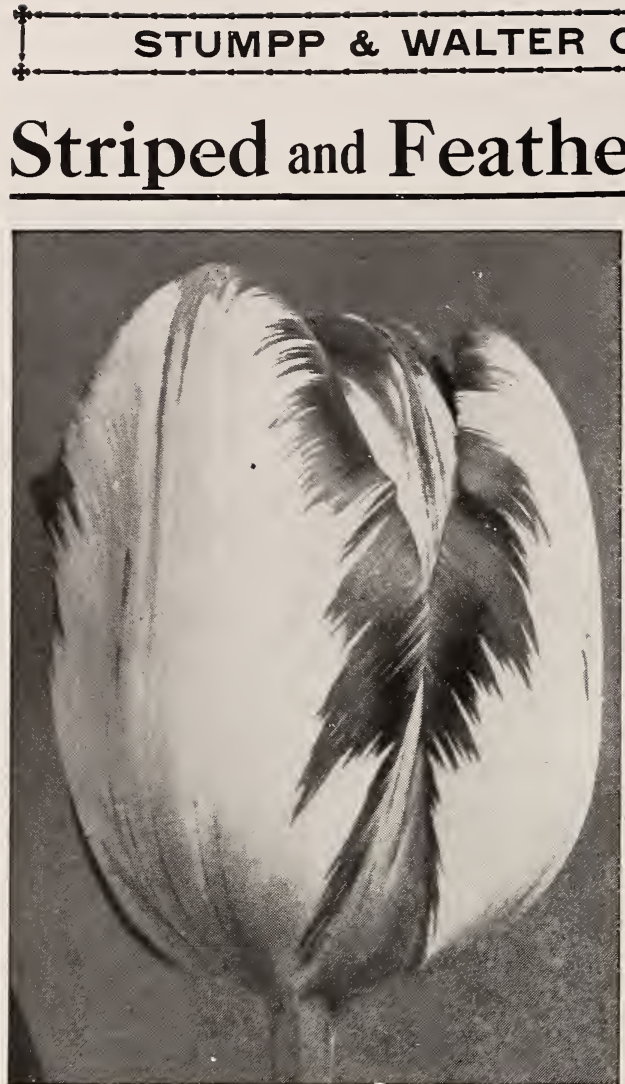

Rose Bybloem Tulip, Athalia

Bybloem and Bizarre Tulips are "rectified" Breeder types. The Tulips are of an old race which has been grown in Holland and in France since the beginning of the seventeenth century, and which caused the famous Tulip craze in 1635. The Bybloems are queerly striped and feathered rose or violet on a white ground. The Bizarres have dark brown stripes and feathering on a yellow ground. The varieties offered are the newer sorts, and the flowers are larger than the older and smallerflowering sorts. They flower about the same time as the Breeder and Darwir Tulips but do not grow quite so tall, and are seen at best advantage when planted in clumps in the herbaceous border or among evergreens and shrubs. The stems average from 18 to 23 inches in height.

ADMIRAL KINGSBERGEN. (Rose Bybloem.) Bright crimson, feathered and flamed with white; large flower. borne on a stiff stem. $\$ 1.80$ per doz., $\$ 14$ per 100 . ATHALIA. (Rose Bybloem.) White, bordered and feathered bright rose. 90 cts. per doz., \$6.50 per 100 .

BLACK BOY. (Bizarre.) Yellow ground, feathered and flamed dark brown. $\$ 1$ per doz., $\$ 7$ per 100 .

EMPEROR DU MAROC. (Bizarre.) Bright yellow ground, feather sd and flamed dark red. 90 cts. per doz., $\$ 6.50$ per 100.

GLORY OF HOLLAND. (Violet Bybloem.) Pure white, feathered and flamed violet-purple. \$1.50 per doz., \$12 per 100 .

LADY STANLEY. (Violet Bybloem.) White, feathered and striped dark violet. 90 cts. per doz., $\$ 6.50$ per 100 .

OVIDIUS. (Bizarre.) Reddish brown ground, feathered yellow; very attractive variety. \$1.10 per doz., \$8 per 100.

PRINS MAURITZ. Yellow ground, variegated dark brown. \$1.10 per doz. $\$ 8$ per 100 .

REINE DE HOLLANDE. (Rose Bybloem.) White, feathered and flamed red: a very attractive and distinctly variegated Tulip. $\$ 1.10$ per doz., \$8 per 100. ROMEA. (Bizarre.) Bright yellow, feathered and bordered with orange-red; a very striking variety of large size. 70 cts. per doz., \$5 per 100.

VONDEL. (Violet Bybloem.) White ground, striped dark violet and feathered light violet. \$2 per doz., $\$ 15$ per 100 .

ROSE BYBLOEM TULIPS, MIXED. 70 cts. per doz., \$5 per 100.

VIOLET BYBLOEM TULIPS, MIXED. 70 cts. per doz., \$5 per 100.

BIZARRE TULIPS, MIXED. An excellent mixture of choice named sorts. 70c. per doz., \$5 per 100 .

\section{REMBRANDT TULIPS}

Rembrandt Tulips are in reality "broken" forms of Darwin Tulips. Each year many of our best varieties of Darwin Tulips show a tendency to break, or become variegated. These Tulips, on account of their odd colorings and variegations, were very popular at one time, and while the modern tendency to favor self-colors is recognized generally throughout all countries, these broken forms are sometimes preferred and possess splendid decorative value. The stems average from I8 to $22 \mathrm{in}$. in height. APOLLO. Lilac-rose and white, striped dark carmine. 70 cts. per doz., \$5 per 100. CARACALLA. White, striped and feathered carmine-red; a very attractive variety. $\$ 1.10$ per doz., $\$ 8$ per 100 .

EROS. Soft lilac, feathered dark violet; not a large but exquisite flower. 80 cts. per doz., \$6 per 100.

JULIENNE. Rose, striped and feathered carmine-purple and white. Edges of petals broadly blotched white makes splendid contrast with the rich color of the flower. 85 cts. per doz., \$6 per 100.

LA COQUETTE. Violet, flamed purple and white; not a large but an exquisite flower 85 cts. per doz., \$6 per 100.

MARCO SPADO. White, flamed bright carmine-red; large flower. \$1.30 per doz., $\$ 10$ per 100.

SEMELE. White, heavily striped and feathered vivid rosy pink. A Tulip of exquisite coloring; large flower. 70 cts. per doz., \$5 per 100.

VICTOR HUGO. Brilliant carmine, feathered white; large flower. \$1.10 per doz., $\$ 8$ per 100.

REMBRANDT TULIPS, CHOICE MIXED VARIETIES. 70 cts. per doz., $\$ 5$ per 100.

\section{PARROT TULIPS}

The petals of these Tulips have peculiarly feathered and fringed edges, and the shape of the flower, especially before it opens, resembles the neck of a parrot. 70 cts. per doz., $\$ 5$ per 100

Amiral de Constantinople. Large, Markgraaf von Baden. Yellow, striped red flowers, tipped with orange.

Cramoisi Brillant. Deep carmine; very handsome.

Lutea major. Large; bright yellow, with crimson and green stripes.

with scarlet and green.

Perfecta. Yellow and red, striped.

Rubra major. Blood-red; handsome.

Mixed Parrot Tulips. $65 \mathrm{cts}$. per doz. $\$ 4.50$ per I 00 .

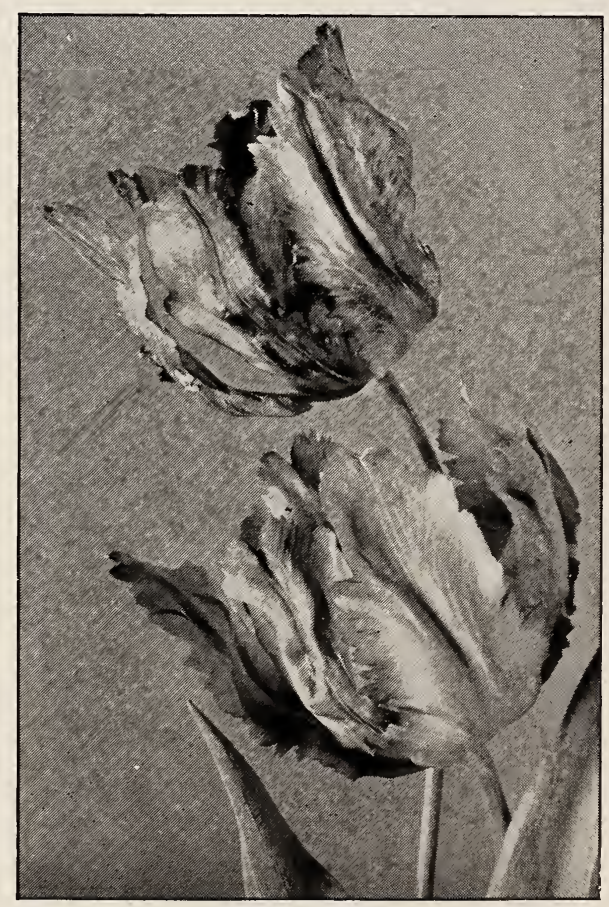

Parrot Tulips 


\section{STUMPP \& WALTER CO.'S SELECTED BULBS DOUBLE EARLY TULIPS}

FLOWERS JUST AFTER EARLY TULIPS, IN LATE APRIL

Double Tulips are chiefly grown for their showy effects in masses, and are very lasting. Where a display of color is desired they are very satisfactory. Excellent for growing in pots or pans, but should not be forced into bloom very early.

The following list contains many of the best tested novelties, as well as all worth-while standard sorts.

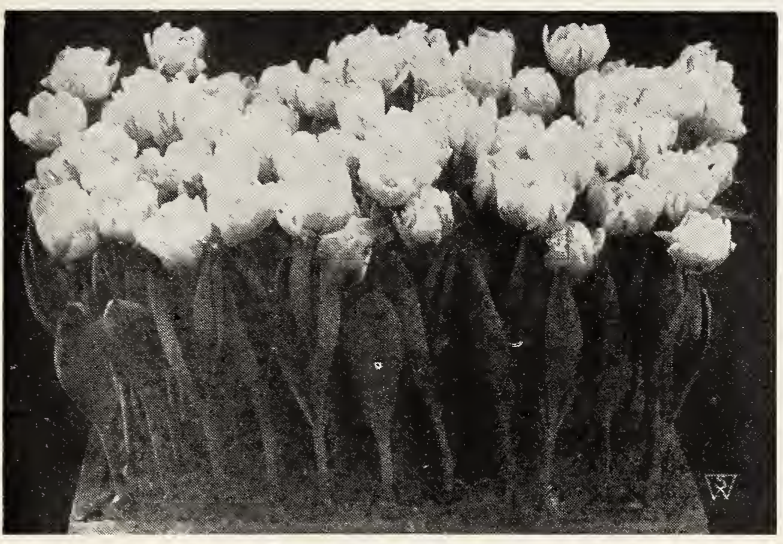

Double Tulip, Murillo

Bleu Celeste. C r4. Soft violet-purple; Doz. Iоo I,000 ing color. A beautiful Tulip for cutting or late forcing. A variety much later than other Double Tulips................ \$o $85 \quad \$ 6$ oo $\$ \$ 58$ oo

Boule de Neige. B Io. Beautiful, large, ing white; greatly resembling a peony in form. Excellent for bedding or forcing....

Cochineal. C ro. Rich, brilliant scarlet; Cochineal. the largest and one of the best double scarlets. When forcing this variety, as well as any other scarlet, care should be taken to have them come slowly,

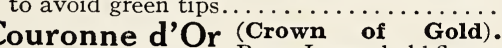
Couronne d'Or (Crown of Gold). of rich golden yellow, shaded copper. Excellent for bedding and winter forcing.........

El Toreador. B I2. Bright orange-scarlet, with a broad margin of buff-yellow. Excellent for pots or bedding. I Io $\quad 8$ oo $\quad 78$ oo

Golden King. A i2. Soft canary-yellow Golden King. shaded deeper yellow. Very fine for forcing or bedding............
mperator Rubrorum. B ro. ExcelImperator Rubrorum. $\mathrm{B}$ ro. Excelfor bedding and forcing. Still remains among the best of the older varieties...... Lac Van Haarlem. $\begin{gathered}\text { C I3. Brilliant rosy } \\ \text { violet; large; splen- }\end{gathered}$ did form. Excellent for pots or bedding ....

Lord Beaconsfield. B r2. Brilliant large flowers of distinct shape.......... Lord Roseberry. B I 2. Delicate light good stem pink; large flower on a petals fall. The color remains until the A splendid sort for early forcing.

Matador. C Io. Glowing scarlet, the purpetals and the perfect egg-shaped flowers make it one of the handsomest of the red Double Tulips......................

$85 \quad 6$ oo $\quad 58$ oo

856 oo 58 oo $85 \quad 6$ oo $\quad 58$ oo Io 8 oo 78 oo oo $\quad 7$ oo 68 oo I 209 O0 88 oo $70 \quad 5$ oo $\quad 48$ oo 856 oo 58 oo
Murillo. C I2. Delicate rose-pink, flushed Doz. Iоo I,000

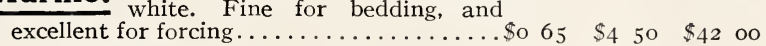

Peach Blossom. C I2. Bright rose-pink,

ing flushed white, deepenwith age to carmine-rose; large. A sport of Murillo. Excellen ${ }^{2}$ for pots........
B I2. Vivid cherry-

Queen Emma. B I2. Vivid cherrystriped white; resembles in color the fine variety Pink Beauty in Single Tulips. Very fascinating on account of its color........

Rose d'Amour. B I2. Pale flesh-rose, soft deepening with age to lovely color. An especially beautiful Tulip for bedding or forcing.

I 30 IO 00

Safrano (Brimstone; Tea Rose). B I2.

This variety is a sport of Murillo; flowers open pale yellow, flushed salmon, but develop a rosy apricot in a day or so. Salvator Rosa. B I2. Beautiful deep white. Excellent for beds or forcing...... Schoonoord. B I2. A beautiful, pure the same excellent forcing qualities, One of the best, if not the best white double...

Van der Hoef. C I2. A beautiful pure riety Murillo. A very fine new variety for

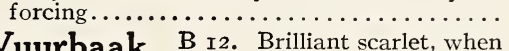
Vuurbaak. B f2. Brilliant scarlet, when orange hue. One of the best scarlets for bedding owing to its sturdy stem......... I oo $\quad \begin{array}{llll}7 & \text { oo } & 68 & 00\end{array}$

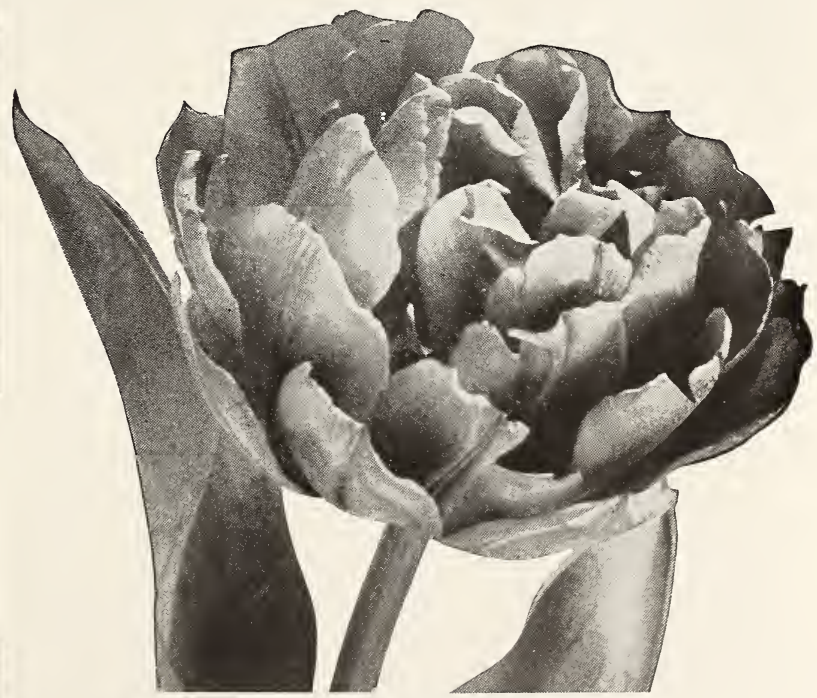

856 oo 58 oo I oo $\quad 7$ oo 68 oo 856 oo 58 oo 856 oo 58 oo $70 \quad 5$ oo $\quad 48$ oo I $20 \quad 9$ oo $\quad 88$ oo

Double Tulip, Couronne d'Or

S. \& W. Co.'s Special Mixture. A mixture consisting of 15 named varieties, blended so as to give an size uniform assortment of all possible colors and shades, all of vigorous habit and large size, uniform height and time of blooming. 60 cts. per doz., $\$ 4$ per 100, $\$ 38$ per 1,000. 


\section{SINGLE EARLY TULIPS For APRIL-BLOMING OUTDDons,}

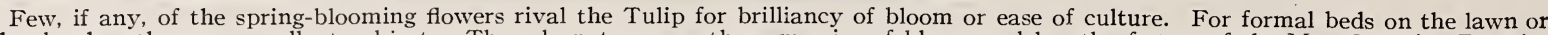

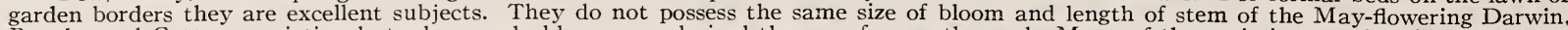

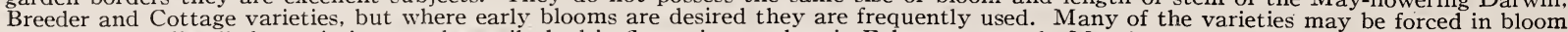
in January, while all the varieties may be easily had in flower in pots late in February or early March.

Culture.-For indoor blooming they require the same cultural treatment as Hyacinths.

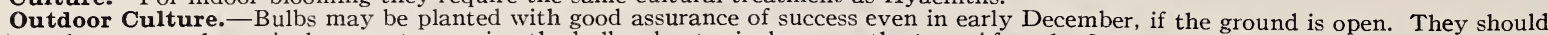

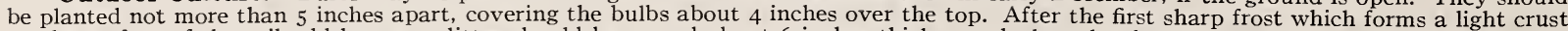

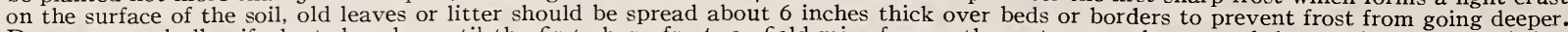

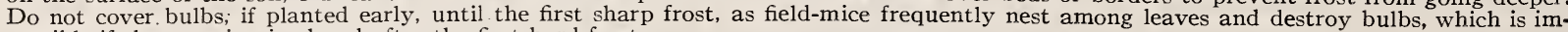
possible if the covering is placed after the first hard frost.

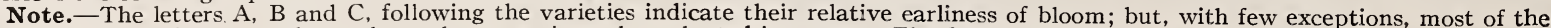
varieties, however, bloom outdoors about the same time when planted in masses. The figures indicate the height in inches.

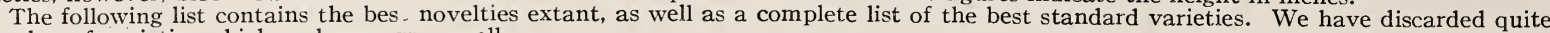
a number of varieties which no longer grow well.

\section{BEST STANDARD AND NEW AND RARE VARIETIES}

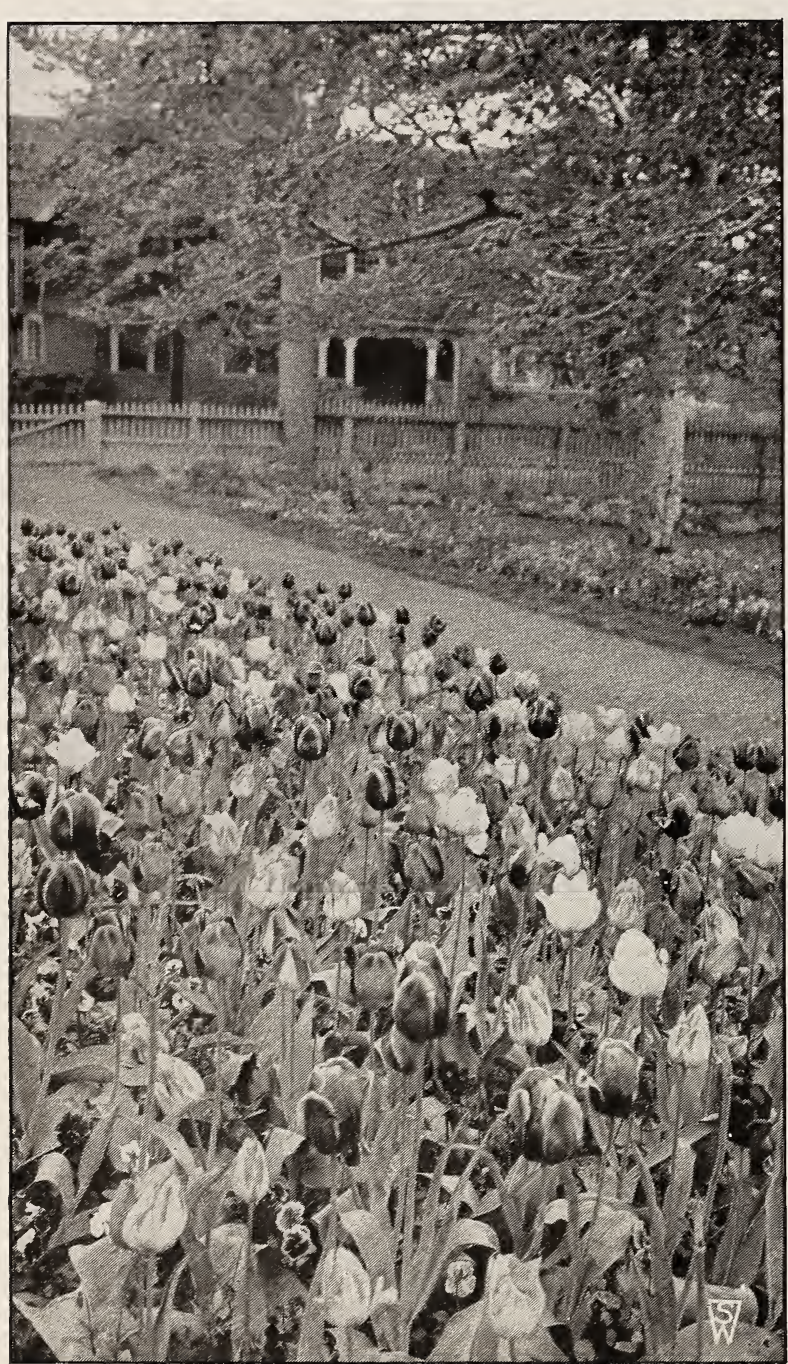

A border of Single Early Tulips

Augusta. B ro. An improvement on the Doz. 100 r,000 but very old variety Rose Gris-de-Lin, ful exhibition variety.

\$o $85 \$ 600 \quad \$ 58$ oo
Belle Alliance. B Ir. Brilliant scarlet, Doz. $100 \quad$ r,000 flower. An excellent variety for early forcing and does very well for bedding also... $\begin{array}{llllll} & 70 & \$ 5 & \text { oo } & \$ 48 & \text { oo }\end{array}$

Brilliant Star. A 12 . Bright vermilas Ven-scarlet, same color as Vermilion Brilliant, but larger and of great substance. Splendid early forcer, flowering easily for Christmas............ I I5 8 oo 78 oo

Cardinal Rampollo. A Ir. A very with clear golden yellow petals which are neatly bordered with bright orange-red. A very early and easy forcer, one that looks well in pans and excellent for bedding also. .

Cerise Gris-de-Lin. C I I. Dark carded fawn and margined crearny white, with yellow base; large flowers of globular form. A novel bedding variety, but must be planted alone; excellent for March forcing. .

Couleur Cardinal. C i2. A bright with a deeper tone or bloom on the outer petals. A bed planted wholly to this variety is a grand sight. Grand for midseason forcing.

Cramoisi Brillant. C I3. G low ing base; long, narrow flowers of perfect form .

Cramoisi Royal. B I4. A large flower of a borne on strong stems. A lovely satiny rose color when grown in pots.

Cullinan. B I3. Creamy white, with edge in color between La Reine Maximus and Flamingo; fine for forcing.

I 00700

6800

De Wet. B I6. Golden yellow, flushed scented flower of erect habit. Quite different in color from any other variety......... $250 \quad 50 \quad 200$

Diana. B r 4. Pure glistening white, with a yelshape. A fine new Tulip which grows more beautiful as it ages...

Enchantress. C ro. A very novel and Enchantress. attractive variety. Bright cherry-red with a broad border of creamy
white; excellent for forcing or bedding..... white; excellent 12 . Carmine-rose, shaded

Flamingo. B r2. Carmine-rose, shaded white and very crinkled, giving the flower a decidedly artistic appearance. A very popular variety among florists for forcing on account of its odd color and habit......

Fred Moore. B I2. An improved form of ruddy apricot, shading at the edges of the rudaly to dull orange-yellow, center marked petals to dull orange-yellow, center mareed medium-sized flower; sweetolive-green; medium-sized flower; sweet-
scented. A lovely color when forced.......

$60 \quad 400 \quad 3800$ 


\section{Single Early Tulips, continued}

Goldfinch. B Ir. Pure deep yellow, re- Doz. Ioo I,000 the life of the flower................. $\$$ o $60 \quad \$ 4$ oo $\$ 38$ oo

Golden Queen. B r3. Golden yellow; Golden Queen. large flower of extrafine form. Excels all existing yellows for substance, and excellent for early forcing...

Ibis. B I4. Quite the finest novelty offered by us this year. A brilliant dark pink color when grown indoors. A grand exhibition variety..........................

Keizerkroon. A I 5. Bright crimsonyellow; excellent, large flower on long stem. Fine bedder; splendid for forcing..........

King of the Yellows. A i 4. Deep low; the flowers are egg-shaped, very substantial and carried on a tall stem, which makes them excellent for cutting. One of the earliest yellows which should be much more used for early forcing.............

Lac Bakhuyzen. A r 4. Light purplesilvery white margin violet, with a broad violet-rose. A splendid tall grower, with pointed petals; excellent for early forcing. .

Lady Boreel ( Joost Van Vonde White). B I3. Snowy white; large, long flower of splendid shape. The finest white for bedding, and superb for pots or pans. Cannot be forced so early as Pelican or White Hawk. .

La Reine. B I2. White, flushed faintly a Reine. with pink. Used largely by florists for early forcing and a very lovely

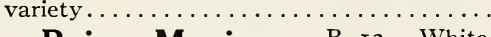

La Reine Maximus. B I3. White, pale rose, the color deepening as the flower ages. A very fine variety..............

La Riante. B I2. Bright rosy pink, flower of great beauty. We recommend this variety for bedding instead of Cottage Maid.

La Remarquable. C I3. Brilliant clareta purple, edged and tipped old-rose. A very large flower of elegant reflexing shape and a rather odd color among early Tulips. Good for bedding or late forcing.

Le Reve (Hobbema; Sarah Bernhardt). siderable favorable comment in our exhibit of bulbs at the New York Flower Show thi spring. The color is old-rose, flushed buff; a very large, globular flower with rounded petals and carried on a strong stem. Excellent for late bedding, and retains color well if not forced before March............

L'Esperance. B I4. Dark garnet with a edged old-rose. An excellent variety on edged old

$\overline{\mathbf{M}}$ ax Havelaar. Very close in color to

Max Havelaar. watermelon-red; rather large, well-formed flowers. A very striking

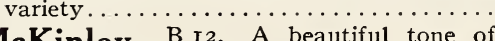

McKinley. B r2. A beautiful tone of attractive variety when forced................

Mon Tresor. A r2. Golden yellow; the Mon Tresor. flowers are large and of a pure color. Mostly used for growing in pots or pans, for which purpose it is best.......

Moonbeam. B i4. Deep primrose-yellow, shading to soft canary at the edges; very large flower of graceful form. An improved form of Primrose Queen.................... 2 oo I $_{5}$ oo
Pelican. A r4. A splendid new, pure Doz. I00 1,000 fully large white variety, and of wonder-

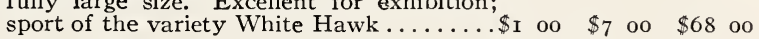

Pink Beauty. C r2. Bright cherry-rose, white. It has no equal as a bedder, for the stem is strong and the white center of the big, fleshy petals shows up very conspicuously against the broad, vivid rose edges. Does well in pans, but not before March........

President Lincoln. B I 2. Large flower violet, slightly paler in tone when grown indoors. A variety that looks well when bedded out with a pale yellow variety ....

Prince of Austria. B r4. Brilliant with a clear yellow base. The flower is large and of a very attractive shade when forced. A splendid bedding variety as well. .
$60 \quad 4$ oo $\quad 3800$

I $20 \quad 9$ oo 88 oo

$60 \quad 4$ oo $\quad 38$ oo

$80 \quad 5 \quad 50 \quad 5200$

856 oо 58 oo

$80 \quad 5 \quad 50 \quad 52$ oo

$\begin{array}{lllll}20 & 900 \quad 88 & 00\end{array}$

I I0 8 o0 78 о0

I $00 \quad 700 \quad 68$ oo

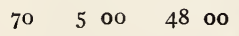

$80 \quad 5 \quad 50 \quad 5200$

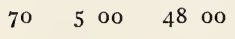

Princess Juliana. B I2. A variety much mingo, but of a deeper shade of pink......

Princess Wilhelmina. $\begin{aligned} & \text { E rz. D e e p } \\ & \text { pink, with }\end{aligned}$ striking white flush on outer petals; long pointed flower. Fine for bedding.

I Io 8 0о 78 00

Proserpine. A r 4. Rosy carmine, with a blue; a very white center marked slatethe easiest and earliest forcing Tulips; very sweetly scented. Good bedding variety also.

Queen of the Netherlands. ${ }_{\mathrm{B}}^{\mathrm{B}} \mathrm{I} 3$. tiful pale rose flower of large size. One of the finest pale pink Tulips for bedding. Good for forcing, retaining its delicate color well if not forced too hard.

$65 \quad 4 \quad 50 \quad 42 \quad 00$

Rising Sun. B I 5. A new variety used its pure yellow color, and wonderful size and substance. The finest golden yellow early Tulip introduced to date $. . . \ldots \ldots .$.

Rose Luisante. $\begin{aligned} & \text { C ro. Brilliant, deep } \\ & \text { rose-pink; large flower. }\end{aligned}$ Splendid for bedding, or pots ............

Sir Thomas Lipton. B I2. D a r k yellow base, marked olive-green. A flower of good substance and large size. A sport of the once popular Pottebakker Scarlet. .

The Pearl. Pale heliotrope, flushed white at base of petals-a color heretofore unknown in early Tulips.... 25020 oo

Van Der Neer. B I2. Deep dark puran Der Neer. ple; a flower of a most brilliant tone and splendid shape. A wonderful color out-of-doors .............. Vermilion Brilliant. $\begin{aligned} & \text { A } 12 . \\ & \text { glistening scar- }\end{aligned}$ let, with a yellow base; very large flower of perfect shape. Splendid for early forcing...

White Hawk. B r2. Lovely pure white, of great substance. A very early forcer....

Yellow Prince. B I2. Clear golden yelby florists for early forcing or bedding.....

S. \& W. Co.'s Special Mixture. A mixture consist. \& W. Co.'s Special Mixture. ing of 25 named varieties, blended so as to give an assortment of all possible colors and shades, all of vigorous habit and large size, uniform height and time of blooming. 50 cts. per doz., $\$ 3.50$ per 100 , $\$ 32$ per 1,000 . 


\section{EXHIBITION HYACINTHS}

Every year our growers prepare to select the finest grade of Hyacinths for us for exhibition. These bulbs are of maximum size, and fully aged for this purpose. The varieties listed below are grown especially for us, and intending exhibitors at the International Flower Show next spring will be interested in our selection of varieties which we believe, when grown for exhibition, should capture First Premiums. The Hyacinth enthusiast who is interested in novelty varieties will also find this list valuable.

We offer only the best sorts. There are several hundred varieties grown abroad, but we do not consider that there are over thirty of them worth growing. Bulbs such as we supply should be planted singly in a 5-inch pot, or four bulbs to an 8-inch bulb-pan. As there is a slight variation in the time of flowering between the different varieties, we have therefore indicated the relative time of blooming, I being early, 4 the latest.

ARENTINE ARENDSEN. I. Pure snow-white, open wide-petaled bells.

BUFF BEAUTY. 2. Pale Naples-yellow, striped dark straw-yellow.
CITY OF HAARLEM. 3. Sof $t$ Naples-yellow, shaded deeper; large; one of the best of the new yellows.

CORREGGIO. 2. A magnificent pure white variety, with large fleshy bells; perfect truss of great size.

DR. LIEBER. 2. Pale lavender-blue, with a faint tinge of dark violet.

ELECTRA. 2. Light silvery blue; enormous spike; full and well finished.

ENCHANTRESS. 2. Delicate porcelain-blue, flushed cornflower-blue, with pale center.

GARIBALDI. I. Deep crimson-red; large spike. The best red for early forcing.

GENERAL VAN DER HEYDEN. I. Dark greyish lavender, with mauve shadings.

GERTRUDE. I. Dark pink; strong, compact spike. A variety used largely by commercial florists on account of its earliness.

GRAND MAITRE. 2. Dark lavender-blue; large bells; well filled truss, borne on unusually strong stem.

KING ALFRED. 3. Lavender-blue, striped and suffused bright steel-blue; rather loose spike, well finished with good bells and dark stems.

KING OF THE BLUES. Bright dark blue; excellent for late forcing.

LADY DERBY. Clear rose-pink. A splendid forcing variety as the strong stems hold the truss well. Considered the finest rose-pink Hyacinth.

LA GRANDESSE. Pure white; long, full spike of perfect form, with waxy bells.

LA VICTOIRE. Bright, glistening carmine-rose; under glass a fine dark pink; well filled spike; strong stem.

L' I N N OCE N CE. I. Pure white; fine truss of large bells, of great substance.

LORD BALFOUR. I. Lilac-rose, tinged dark violet - a distinct color. The best Hyacinth of this color.

MARCONI. 2. Bright deep rose flushed white; short spike of fine form. MENELIK. 2. Deep black-blue; large, well-formed truss with bells of good size, best of the so-called "blacks."

PERLE BRILLANTE. 2. Light blue, lavender; big bells on a large, finely formed, stiff spike.

QUEEN OF THE PINKS. 3. Very bright rose-pink, of unusually clear tone; large spike w' th large bells.

SCHOTEL. I. Soft light blue; very long and perfect truss, with arge bells; easily forced.

YELLOW HAMMER. I. Creamy yellow; compact spike and large bells. A good standard yellow.

Special Offer. We place large contracts and thus above varieties pick of the crop. an to offer at a uniform price of $25 \mathrm{cts}$. each, $\$ 2.50$ per doz., $\$ 15$ per 100 . 


STUMPP \& WALTER CO.'S SELECTED BULBS

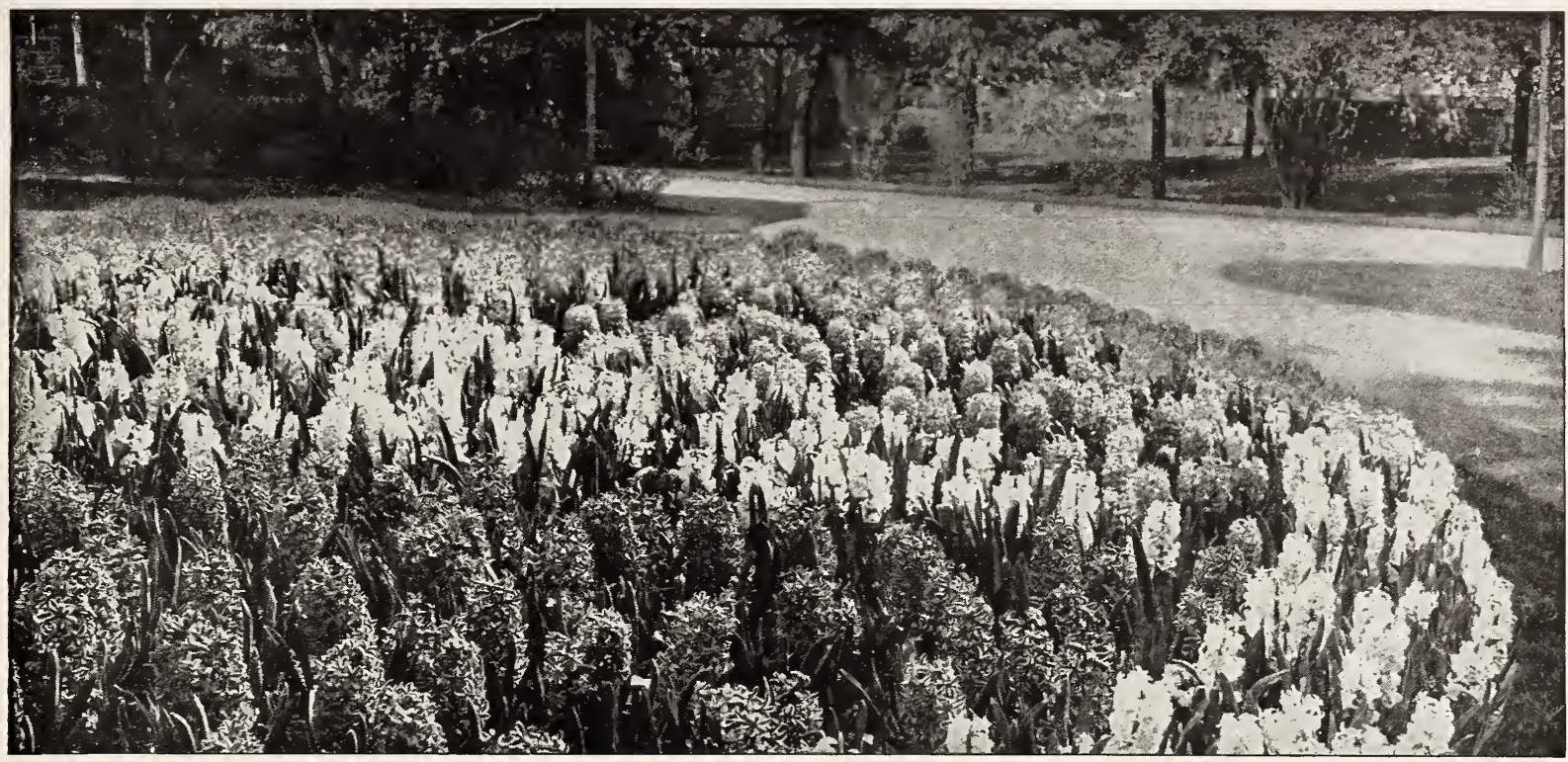

\section{MATCHLESS BEDDING HYACINTHS}

Special named varieties in distinct shades of color, to flower at the same time BULBS MEASURE 7 TO 8 INCHES IN GIRCUMFERENCE

The Hyacinth chosen to represent each of the following shades of color is a variety which, we have found from trials, will be best in the three essential requirements: Best in its color; stoutest stem; largest truss of bells; so our customers will know that we have avoided using such varieties that are of weak stem, and that do not support the blooms.

\section{CULTURE}

These Hyacinths should be planted from 6 to Io inches apart, and covered with at least 4 inches of soil from the top of the bulb. For beds or borders close to the conservatory or dwelling, 6 inches will make a fine display; but where the beds are planted to be viewed from a distance, they may be planted ro inches apart. Hyacinths planted alternately with narcissi produce a most graceful effect, and for this combination 6 inches from bulb to bulb is also a very suitable distance. It is advisable to cover, after the bulbs have been planted, with leaves or some heavy material that will prevent them from freezing or being affected by early spring frosts after they have started.

Hyacinths, as well as narcissi, should be planted by November $\mathbf{I}$ in this latitude, as they are the better for early planting. Tulips may be planted up to December I, weather permitting.

\begin{tabular}{|c|c|c|c|c|}
\hline Matchless & Bedding Scarlet & $\begin{array}{c}\text { Doz. } \\
\$ 125\end{array}$ & $\$ 9 \stackrel{100}{00}$ & $\begin{array}{c}1,000 \\
\$ 8500\end{array}$ \\
\hline Matchless & Bedding Pink. & 125 & 900 & 8500 \\
\hline Matchless & Bedding Light Blue & 125 & 900 & 8500 \\
\hline Matchless & Bedding Dark Blue & 125 & 900 & 8500 \\
\hline Matchless & Bedding Pure White & 125 & 900 & 8500 \\
\hline Matchless & Bedding Mauve & 125 & 900 & 8500 \\
\hline Matchless & Bedding Deep Yellow & 125 & 900 & \\
\hline
\end{tabular}

\section{Suggestions for Effective Color Combinations}

1. Matchless Bedding Pink and Light Biue.

2. Matchless Bedding Light Blue and Deep Yellow.
3. Matchless Bedding Light Blue and Dark Blue.

4. Matchless Bedding Dark Blue and Deep Yellow. 


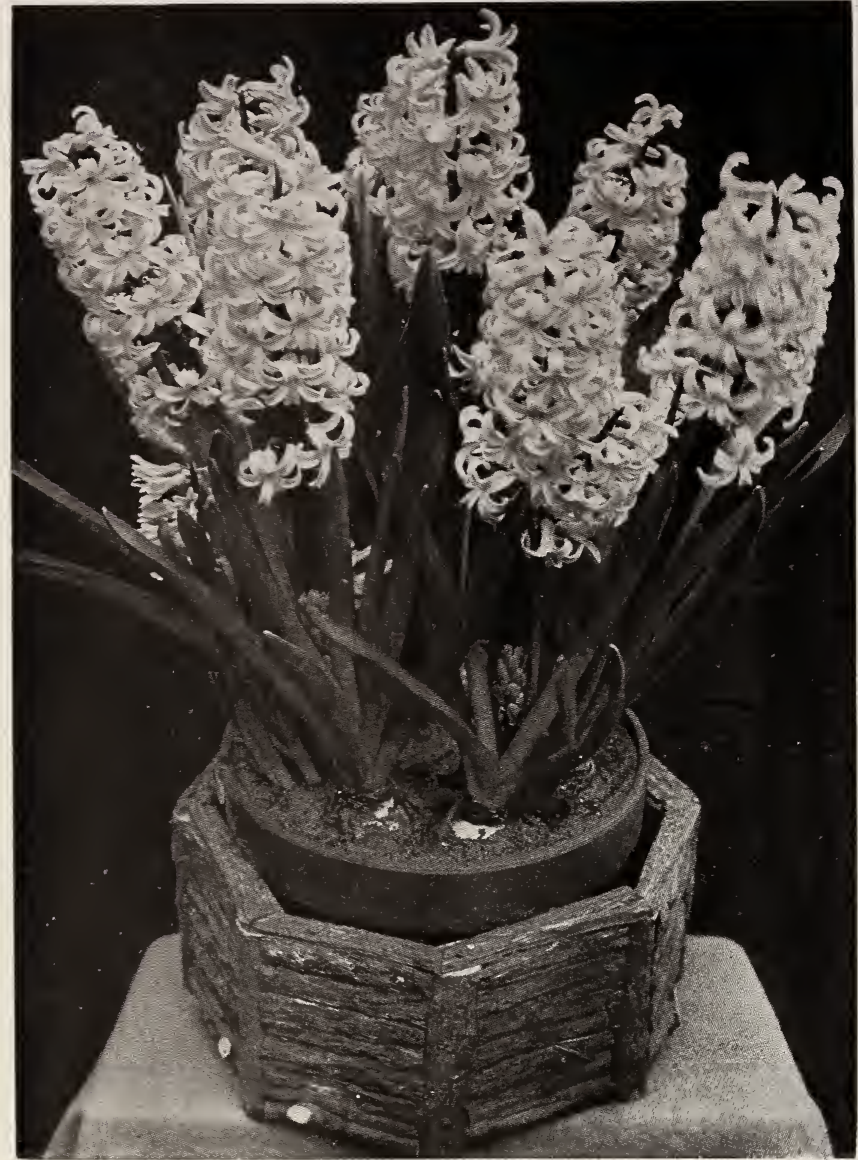

Miniature Hyacinths

\section{French Roman Hyacinths}

French Roman Hyacinths are among the earliest bulbs to be had in flower. The bulbs arrive from France late in August, and, like all bulbs grown in the south of France, they may be had in flower from November all through the winter months, if potted up in September and at intervals of every two weeks. They are much prized for pots or cutting on account of their graceful appearance and delicate fragrance. The bulbs are about the same size as the Miniature Dutch Hyacinths offered on this page, and may be planted six or seven to a 5- or 6-inch pot, or ten to twelve bulbs to an 8- or 9-inch bulb-pan. The flowers are smaller than those of the Dutch Hyacinth, and are borne in great profusion, the larger bulbs frequently having three to five graceful spikes of bloom. Their ease of culture and earliness of bloom suggest their use. The white variety is the most reliable. They are not hardy in our northern climate, and should not be planted outdoors. The general culture given for Hyacinths on page 16 is suggested

White Doz. $100 \quad 1,000$ Jumbo bulbs, I3 to I5 ctms............... Single Rose. First-size bulbs.............. I 30 10 00.9500 Single Blue. First-size bulbs............... I 30 Io oo 9500 Single Yellow. First-size bulbs............... I 30 ro oo 95 oo Double Rose. First-size bulbs................ I 30 r 10 oo 9500

Our patrons desiring Hyacinths for culture in glasses are advised to select varieties from page 16. We offer Hyacinth Glasses, both Belgian and Tye shape, at $45 \mathrm{c}$. each, $\$ 4.50$ per doz.

\section{Miniature Hyacinths}

\section{(DUTCH ROMANS)}

The following method of growing Hyacinths for winterflowering in the house has given the most satisfactory results. A number of florists use it for creating something new in the line of an Easter display, with the result that there is always a much greater demand than supply, owing to the beautiful display the Hyacinths in pans make. The secret of acquiring success is simply the following: Plant only one kind in a pan, in order to have them all bloom at once, and to have them all the same shade. The following varieties are the best sorts. By planting Io to I 2 bulbs of any one variety mentioned, in a pan 8 to 9 inches in diameter, and following the directions for planting in pots, the most satisfactory results will be obtained. In ordering bulbs for this purpose, be sure to mention Miniature Hyacinths.

Gertrude. Fine pink.

La Victoire. Bright red.

Gigantea. Pale pink.

La Grandesse. Pure white; large spike.

Grandeur a Merveille. Blush-white.

Baroness Van Thuyll. Snow-white.

Grand Maitre. Bright blue.

King of the Blues. Dark blue.

Queen of the Blues. Porcelain-blue, extra fine.

Price of any of above named varieties, 75 cts. pez doz., $\$ 5$ per $100, \$ 45$ per 1,000 .

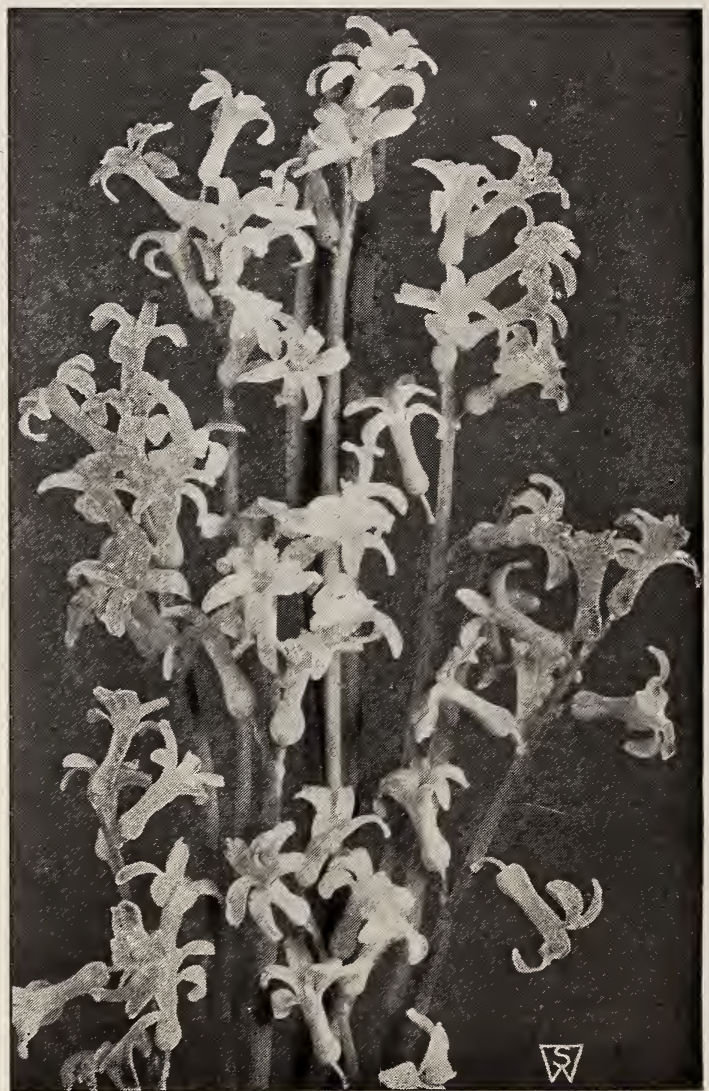

French Roman Hyacinths 


\section{Polyanthus Narcissi}

VARIETIES FOR EARLY FORGING

Not for Outdoor Planting, except south of the Carolinas

We have decided to discard all the varieties of these Narcissi that are usually grown in Holland and would recommend our patrons to make selections from the Poetaz type listed on page 23 of this catalogue. The varieties Paper-White Grandiflora, Grand Soleil d'Or, and Gloriosa we list below. These are grown for us in the south of France. They arrive in this country in August and are used principally by the florists for forcing. As these varieties are matured earlier in the south of France than in Holland, they may be brought in flower in the house or greenhouse in December or January, if potted up in September.

Gloriosa. A new variety similar in character to Grand cups. Very good for early forcing. $\$ \mathbf{1 . 7 5}$ per doz., \$12 per $100, \$ 100$ per 1,000 .

Grand Soleil d'Or. A popular yellow bunch-flowering Flowers a clear, sunny variety of the Polyanthus type. Excellent for early flowering ind oors. \$1.75 per doz., $\$ 12$ per $100, \$ 100$ per 1,000 .

\section{Suitable for Growing in Water Giant Paper-White Grandiflora}

This large-flowering Paper-White Narcissus is such an improvement over the ordinary Paper-White that we have decided to discontinue the sale of the latter. It can be had in bloom from Christmas to Easter. Plant bulbs in shallow boxes or pots so that they almost touch each other, and store in a cool cellar or shed until rooted. By bringing into the light during early November they may be had in bloom for Christmas. Excellent results can be obtained by growing in bowls of water and pebbles or moss. the same

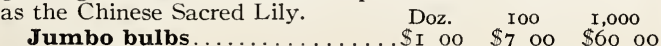
First Size............. $75 \quad 6$ oo 50 oo

GLASS BOWLS. For three bulbs of Paper-White Grandiflora Narcissi or Double Roman Narcissi. 35 cts. each, $\$ 3.50$ per doz. For 6 bulbs, 50 ets. each, \$5. per doz. PEBBLES. Carefully screened and selected. Quart box 20 cts., 2 qts. for 35 ets.

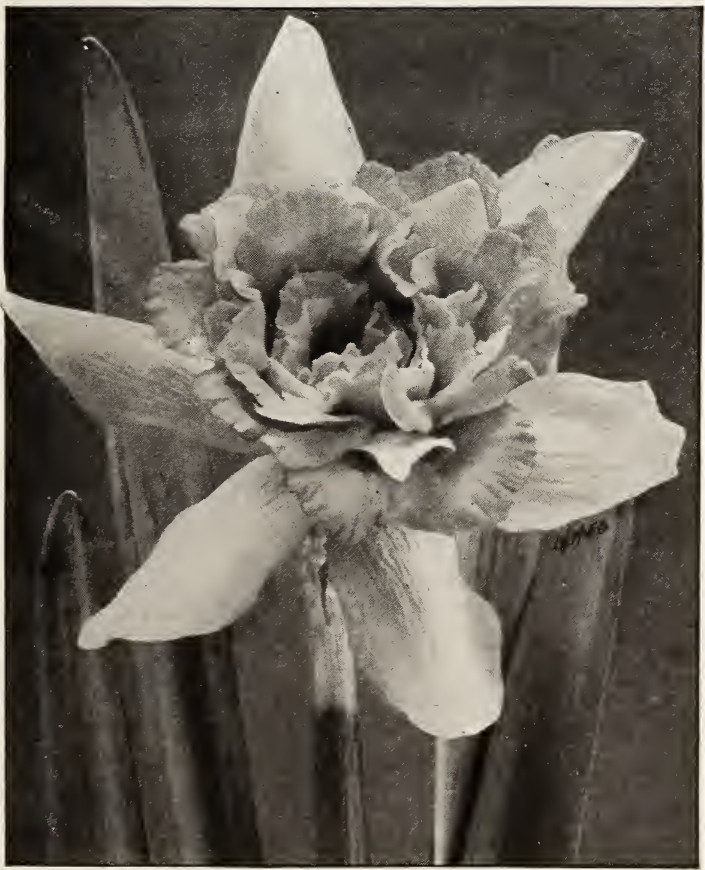

Double Narcissus, Von Sion

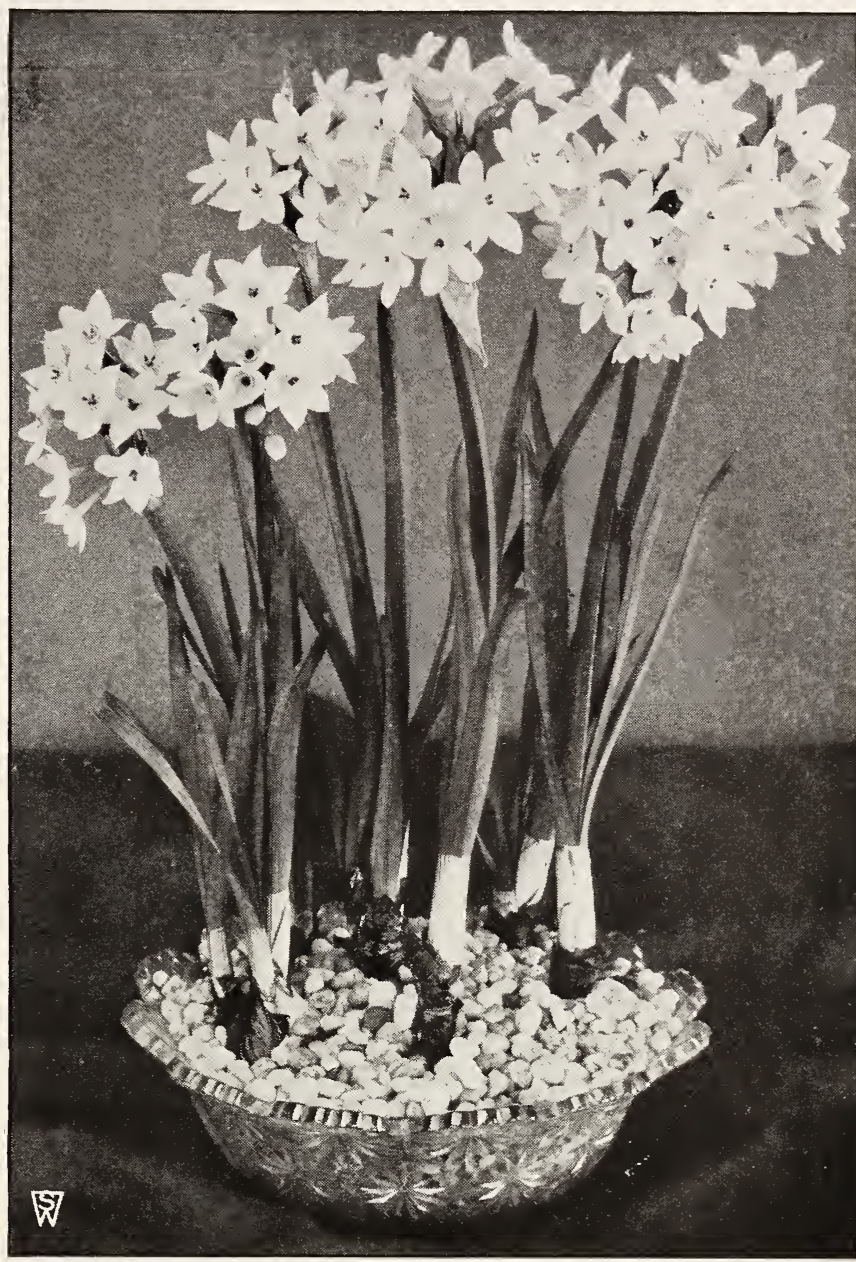

Paper-White Grandiflora Narcissi growing among pebbles in water

\section{Double Narcissi}

\section{DAFFODILS}

The Double-flowering Daffodils offered in our list may be planted out doors, but are admirably adapted for indoor growing in pots and pans, or may be forced in flats for cutting purposes.

Von Sion, S. \& W. Co.'s Exhibition Grade. B. This, the most Double Narcissi, is famous as the Old Double Yellow Daffodil. Rich golden yellow perianth and trumpet. This is one of the best winterflowering and forcing sorts. Height I 8 inches.

Jumbo Exhibition Grade. This grade of Double Von Sion is selected specially for us from the very largest double-nosed bulbs, and are what is termed top-roots. Our large importations of this variety make it possible for us to secure this very fine grade of bulbs. Three bulbs planted in an 8-inch bulb-pan make an excellent show, and give four or five strong and perfect blooms. \$I per doz., \$7 per I 0o, \$65 per I, 00o. Selected Single-Nose. Will produce one fine flower. $70 \mathrm{cts}$. per doz., $\$ 5$ per IOO, \$45 per I, 000.

ALBA-PLENA ODORATA (The Double White Poet's Narcissus, or Gardenia-flowered Daffodil). D. Double, snow-white, gardenia-like flowers exquisitely scented. Height I $_{5}$ inches. 10 cts. each, 75 cts. per doz., $\$ 5$ per 100, \$45 per 1,000 .

ORANGE PHOENIX (Eggs and Bacon). D. Beautiful, double, white flowers, with orange nectary. Splendid for pot culture and cutting, and for garden decoration. Height I 7 inches. 10 cts. each, 90 cts. per doz., $\$ 6$ per $100, \$ 55$ per 1,000 .

SULPHUR (or SILVER) PHGNIX (Codlins and Cream). D. Large, creamy white flowers, sulphur nectary. Exquisite corsage flower; fine for growing in pots. Height I 8 inches. 10 cts. each, 90 ets. per doz., $\$ 6$ per $100, \$ 55$ per 1.000 . 


\section{NARGISSI or DAFFODILS}

No garden would be complete without the Narcissus or Daffodil. The innumerable positions in the garden in which their use may be availed of is responsible for their popularity. It is not only for garden culture that they are largely used, but many of the varieties are extensively grown in pots or pans for indoor decoration during late winter months. Some varieties in our list may be forced into bloom as early as January. Their simple beauty of form, dignity of habit, elegance of bloom and ease of culture, account for the new interest amounting to enthusiasm of flower-lovers all over Europe. Each year we are greeted with a prof usion of novelties, many of which, on account of the high prices, are not available for immediate use.

All the varieties of Narcissi or Daffodils offered in our catalogue, with the exception of the Polyanthus Narcissus and such other few sorts as are especially noted, are perfectly hardy, and will continue to flower outdoors each year if given a congenial location and not disturbed. Where they are used for bedding, and must be lifted, it is wise to permit bulbs to remain after flowering until the foliage turns brown down to the ground, then lifted, and the earth shaken from the bulbs; they should be stored in a cool, dry place. Narcissi, like hyacinths, should be planted by early November, and should not be allowed to remain out of the ground so long as tulips, which may be planted up to hard frost.

CUltuRE.- - Owing to the various sizes of the bulbs, it is not advisable to state the exact depth to plant, but the simple rule of covering the bulb one and a half times its own depth, and making the distance between the bulbs 3 to 4 inches for the smaller sorts and 5 to 6 inches for the larger ones, is a good one. For greenhouse or window-garden culture treat them the same as hyacinths, except that three or more bulbs of one variety should be planted in a pot, and not single specimens.

Where a succession of blooms is desired for outdoors as well as indoors, we have arranged the following code: A, first early; B, second early; C, midseason; D, late; E, very late.

Note.-In describing Daffodils, Narcissi, etc., we have referred to the "perianth" and "trumpet," "crown" or "cup." The "perianth" is the surrounding row of petals or wings, and the other terms apply to the central funnel-like tube.

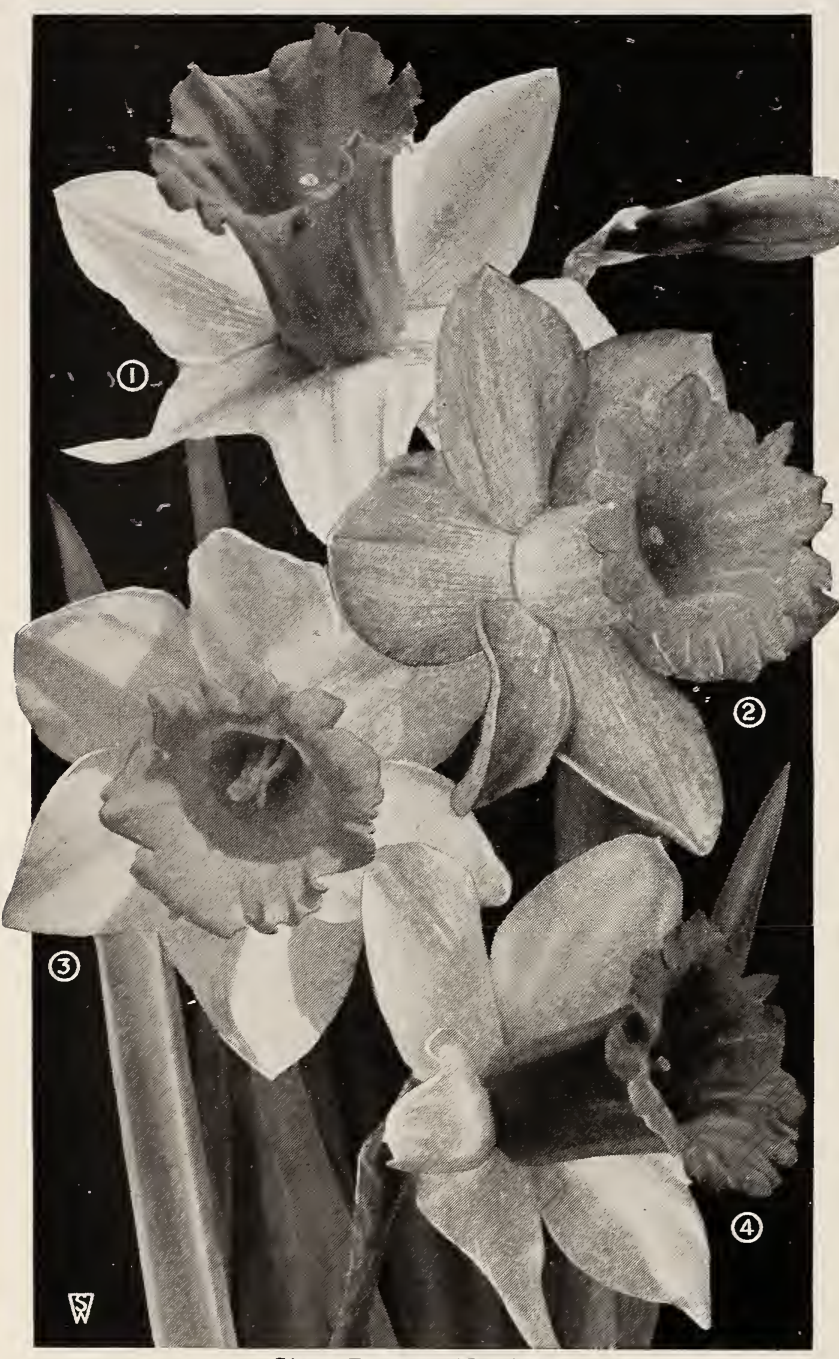

Giant Trumpet Narcissi

$\begin{array}{ll}\text { 1. Van Waveren's Giant. } & \text { 3. Glory of Noordwijk. } \\ \text { 2. King Alfred. } & \text { 4. Spring Glory. }\end{array}$

\section{Giant Trumpet Varieties,} Including New and Rare Sorts

The flowers of the Giant Trumpet varieties are of large size; the "perianth," or wing-like petals, according to the variety, measure from 2 to 4 inches across, and the "trumpets," or central funnellike tubes, vary from 3 to 4 inches in length. Flowers are borne on strong, stiff stems, from I 2 to 18 inches high.

Albicans. Discarded. Mme. de Graaff recommended instead.

Alice Knights. White perianth with gracefully twisted petals; elegant form. Quite the earliest-flowering White Trumpet for outdoors or pots. 40 cts. each, $\$ 4$ per doz., $\$ 30$ per 100 .

Duke of Bedford. B. White perianth, with loose, spreading frilled at the mouth petals and long, deep yellow trumpet well deep trumpet ant in color between the A splendid exhibition sort. Height I6 inches. 35 cts. each, $\$ 3.50$ per doz., \$25 per 100 .

Emperor. C. Perianth deep primrose-yellow, trumpet rich yellow; a very large flower. Excellent for naturalizing

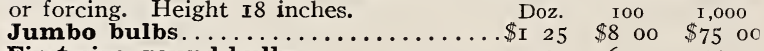
First-size, round bulbs............... $90 \quad 6$ oo $\quad \begin{array}{r}55 \\ 00\end{array}$ Emperor. (French.grown.) A strain of the above described vaearly forcing. $\$ 1.50$ per doz., $\$ 9$ per $100, \$ 85$ per 1,000 .

Empress. C. White perianth of great substance; trumpet rich chrome-yellow. Showy for border or naturalizing. Does equally well forced. Height I8 inches. Doz. I00 I,000 Jumbo bulbs ................... \$I 25 $\$$ \$7 oo $\$$ \$75 oo First-size, round bulbs............. $90 \quad 6$ oo 55 oo

Glory of Leyden. C. Perianth pale yellow, broad and yellow; enormous flower of great vigor and substance. An especially fine variety for borders and excellent for pot culture. Should not be forced hard. Must be planted early. Height I 5 inches. 15 cts. each, $\$ 1.50$ per doz., $\$ 10$ per 100 .

Glory of Noordwijk. B. One of the best and most atsulphur-white, trumpet chrome-yellow, very long and elegantly reflexed at the brim; of good size and substance. Grand for pots or cutting. Height 14 inches. 15 ets. each, $\$ 1.50$ per doz., $\$ 10$ per 100 .

Golden Spur. A. A very good variety, both perianth and trumGet being of a rich vellow color; foliage very broad and striking. It is of unusually robust habit and and extremely free passed for garden, pots, or forcing. Early and Doz. I00 I,000 Jumbo bulbs First-size, round bulbs

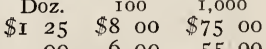
$90 \quad 6$ oo 55 oo

Golden Spur. (French-grown.) A strain of the above described here for early forcing. $\$ 1.50$ per doz., $\$ 10$ per $100, \$ 95$ per 1,000 . 


\section{Giant Trumpet Narcissi, continued}

Grace Darling. Discarded. Mme. de Graaff recommended instead. Henry Irving. Discarded. Emperor recommended instead. Horsfieldii. Discarded. Victoria recommended instead.

King Alfred. C. A king among the new varieties, one that responds splendidly to forcing and one that you should grow a few of. For pans or pots for exhibition, its size, general vigor, and depth of color put it in a distinct class of the Finest Giant Golden Yellow Narcissi. Wherever this Narcissus has been exhibited it has caused a sensation. Perianth of ten measures 4 inches across, trumpet fully 2 inches.

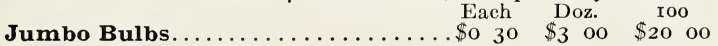

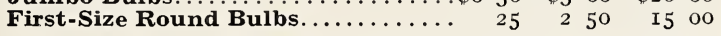

Lord Roberts. Yellow Trumpet. Perianth of remarkable substance, something like two triangles of petals superimposed; long, sturdy trumpet, wholly in keeping with the noble character of the flower. A self-toned, deep, golden yellow. A free bloomer and tall grower of enormous size and color. Height 23 inches. 50 cts. each, $\$ 5$ per doz., $\$ 40$ per 100.

Loveliness. B. White Trumpet. Broad, smooth perianth of snowy whiteness, bold substance; very elegant white trumpet expanded at the mouth. A very graceful and refined flower. Considered the best white trumpet Daffodil. Height I 4 inches. 50 cts. each, $\$ 5$ per doz., $\$ 35$ per 100.

Mme. de Graaff. C. Pure white perianth, trumpet primrose, A good white for exhibitiossing into white, well formed at the brim. , growing in pots or pans for decoupon receipt and planted; if permitted to remain will quickly decay. Height I5 inches. 15 cts. each, $\$ 1.50$ per doz., \$10 per 100.

Olympia. B. Perianth light chrome-yellow, trumpet deep chromelympia. yellow; of huge dimensions. Splendid exhibition sort; a variety in the same class as King Alfred; of wonderful constitution and size. Height I 5 inches. 40 cts. each, $\$ 4$ per doz., $\$ 30$ per 100 .

Peter Barr. White Trumpet. White perianth of rather loose white, very long and beautifully recurving at brim. A flower of exquisite symmetry, fine substance, and very noble character, the largest White Trumpet in our list. Strong grower and free bloomer. Height I 5 inches. \$1 each, \$10 per doz., \$75 per 100.

Spring Glory. Clear white perianth with long petals of well reflexingt splendid form, long trumpet of deep yellow, the best of the newer Daffodils for pot culture. 20 cts. each, $\$ 2$ per doz., $\$ 15$ per 100 .

Treserve. B. Yellow Trumpet. Perianth primrose-yellow, reserve. slightly hooded; very large trumpet of rich canaryyellow, broad at the mouth and deeply flanged. Height 17 inches. 40 ets. each, $\$ 4$ per doz., $\$ 30$ per 100 .

Vanilla. C. This is a grand, tall-growing and very handsome variety, having a fine, bold trumpet of deep yellow, with a paler perianth, and possessing the added charm of a most pleasing and delicate odor. It flowers the same time as Emperor, and is a good variety for forcing. Height 20 inches. 15 cts. each, $\$ 1.50$ per doz., $\$ 10$ per 100.

Van Waveren's Giant. B. Bicolor Trumpet. Broad bright yellow trumpet with perianth of campanulate form, very large, open mouth flanged at Height 17 inches. 40 cts. each, $\$ 4$ per doz., $\$ 30$ per 100 .

Weardale Perfection. Perianth milk-white with broad, overrose-yellow; elegantly fluted lapping petals; long trumpet of primfree bloomer. 30 cts. each, $\$ 3$ per doz., $\$ 20$ per 100.

\section{VICTORIA B}

A Bicolor famous for its large and durable flowers which stand boldly erect; broad perianth of creamy white; large, broad, fluted trumpet of rich yellow. A strong grower, with massive flowers. Fine for forcing, the flowers lasting in excellent condition long after being cut. Height 16 inches. Doz. roo $\mathrm{r}, 000$

Jumbo bulbs.

First-size, round bulbs

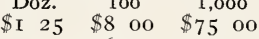

Victoria (French Grown.) We also offer a selected stock of this variety grown in the south of France for earliest forcing. $\$ 1.50$ per doz., $\$ 10$ per $100, \$ 95$ per 1,000 .

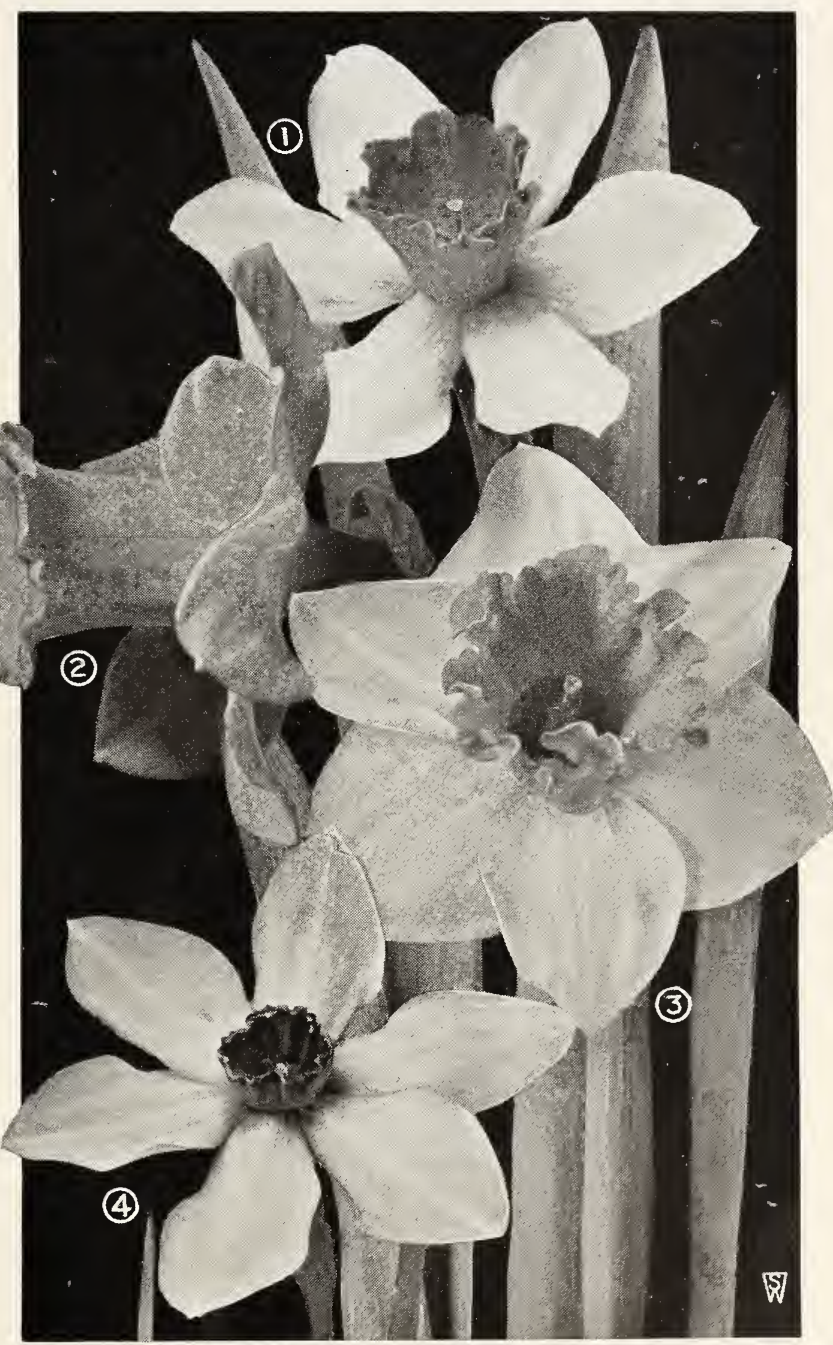

Giant and Medium Trumpet Narcissi

1. Sir Watkin (Medium). 3. Victoria (Giant)

2. Empress (Giant). 4. Conspicuus (Medium)

Giant Trumpets in Mixture. For naturalizing. Each year we import large quantities of these bulbs for naturalizvare varieties which we have in surplus for this purpose, which we offer at the very low price of $\$ 4$ per $100, \$ 35$ per 1,000 . 


\section{Medium Trumpet Narcissi, or Daffodils}

This is also a very popular type or rather types of the Narcissus or Daffodil family. Splendid for garden culture, in pots or pans, or in flats, for cut-flowers.

The following varieties are grouped in some catalogues under the headings, Barrii, Incomparabilis and Leedsii types.

NOTE.- "Perianth" is surrounding row of petals, or wings; "crown" or "cup" is the central cup or funnel-like tube.

BARRII. Daffodils belonging to this group are crosses between Yellow Giant Trumpets and the Poet's Narcissi. The crown usually is not over one-third the length of the perianth petals.

INCOMPARABILIS. The Incomparabilis varieties are also crosses between the Yellow Giant Trumpets and the Poet's Narcissi, but the crowns are larger than those of the Barrii group, sometimes being three-fourths of the length of the perianth petals. The color of the perianth is either yellow or white.

LEEDSII. These are crosses between White Giant Trumpets and the Poet's Narcissi. The crowns are as large as those of the Barrii and Incomparabilis groups, but the perianth petals are always white, and the crowns are mostly white or light yellow.

Albatross. (Barrii.) C. Large, flat, white perianth; cup pale the brim. Solendid forcing and garden variety. Height 20 inches. 15 cts. each, $\$ 1.25$ per doz., $\$ 8$ per $100, \$ 75$ per 1,000 .

Autocrat. (Incomparabilis.) C. Clear golden yellow; broad interianth tending to reflex, cup widely expanded at the 20 inches. Selected bulbs, 15 cts. each, $\$ 1.25$ per doz., $\$ 8$ per 100, \$75 per 1,000.

Bernardino. (Incomparabilis.) Very large, creamy white erianth of great substance; large cup of pale lemon-yellow, flushed and edged pinkish apricot, and very heavily frilled. Height 20 inches. \$1 each, $\$ 10$ per doz.

Conspicuus. (Barrii.) C. Large, broad-spreading perianth of Conspicuus. pale yellow, short darker yellow cup, brightly for midseason forcing, and good for any position in the garden. Height 2 I inches. Selected bulbs, 10 cts. each, 90 cts. per doz., $\$ 6$ per 100, $\$ 55$ per 1,000 .

Duchess of Westminster. (Leedsii.) C. Pure white perianth; cup pale canary-yellow, slightly darker at the edge, passing into ivory-white; large starlike flower of exquisite beauty. One of the best of the Leedsii for exhibition. Height r 6 inches. 15 cts. each, $\$ 1.25$ per doz., $\$ 8$ per 100, \$75 per 1,000 .

Frank Miles. (Incomparabilis.) C. Perianth pale yellow, rank Miles. elegantly twisted; cup bright yellow; large flowers. Effective planted in clumps in the border; also grown extensively for cutting; very good for pot culture. Height 2 I inches. 10 ets. each, $\$ 1$ per doz., $\$ 7$ per 100, $\$ 65$ per 1,000 .

Great Warley. (Incomparabilis.) Broad, massive perianth of creamy white, fully 5 inches across when well grown; rich golden yellow crown, I I/2 inches wide. A very striking and beautiful flower. Height I8 inches. \$1 each, $\$ 10$ per doz.

Lady Godiva. (Barrii.) C. Large, spreading perianth of pure scarlet. A splendid variety in every way; excellent if planted out in combination with the variety Conspicuus. Height 18 inches. 15 cts. each, $\$ 1.25$ per doz., $\$ 8$ per $100, \$ 75$ per 1,000 .

Lord Kitchener. (Leedsii.) Large, snowy white perianth, of the palest primrose, widely open at mouth and elegantly crimped and fluted at the brim. A flower of perfect quality, one of the most desirable in its class. Height $2 \mathrm{I}$ inches. $60 \mathrm{cts}$. each, $\$ 6$ per doz., $\$ 40$ per 100 .

Lucifer. (Incomparabilis.) C. Perianth sulphur-white, with Lucifer. long, well-rounded petals; cup chrome-yellow, with intense orange-scarlet suffusions. A bold, showy flower for outdoors, holding its color well, and splendid for exhibition. Height I8 inches. 10 cts. each, $\$ 1$ per doz., $\$ 7$ per 100, $\$ 65$ per $1,000$.

Masterpiece. (Barrii.) Perianth sulphur-white with broad, character, eye orange-scarlet, quite flat and beautifully crinkled, the color covering the entire surface of the inch-wide eye. Height 22 inches. 40 cts. each, $\$ 4$ per doz., $\$ 30$ per 100.

Mermaid. (Leedsii.) Large white perianth, with smooth, overmaid. lapping, and rather pointed petals; very large bold crown, elegantly recurving and fluted at brim, of pale creamy prim$\$ 4$ per doz., $\$ 30$ per 100 . Mrs. Langtry. (Leedsii.) D. A remarkably free-flowering vaers; broad white perianth, white cup opening pale primrose. On account of its low price it is largely used for naturalizing. It is good, also, for potting. Height 16 inches. Selected bulbs, 10 cts. each, 90 cts. per doz., $\$ 6$ per $100, \$ 55$ per 1,000 .

Red Beacon. (Barrii.) Broad white perianth of splendid subReacon. stance, with broad well-frilled cup of dazzling orange-scarlet. A very striking variety on account of its brilliant coloring. 35 cts. each, $\$ 3.50$ per doz., $\$ 25$ per 100 .

Sir Watkin. (Incomparabilis.) C. Perianth primrose-yellow; large and well-formed yellow cup, tinted deep yellow. A giant among the Medium Trumpet sorts. A grand flower of wonderful substance for garden culture or pots, this variety frequently has flowers 5 inches across, and its splendid proportion and ease of culture cause it to be one of the most popular of the older varieties. Height I8 in. Each Doz. I00 I,000 Mother bulbs................ \$O I5 $\quad \begin{array}{llllllll} & 25 & \$ 8 & \text { oo } & \$ 75 & 00\end{array}$ First-size, round bulbs......... ro 90 ro 6 oo 5500 White Lady. (Leedsii.) C. Broad, white perianth of perfect Worm; small cup of pale canary, beautifully crinkled. A new sort that is conceded to be one of the best. Fine for outdoor planting, making a splendid cut-flower; good for pot culture also. Height 20 inches. 15 cts. each, $\$ 1.25$ per doz., $\$ 8$ per $100, \$ 75$ per 1,000 .

Will Scarlett. (Incomparabilis.) Creamy white perianth; cup widely expanded and of a brilliant orange-scarlet. elegantly frilled. 30 cts. each, $\$ 3$ per doz., $\$ 20$ per 100 .

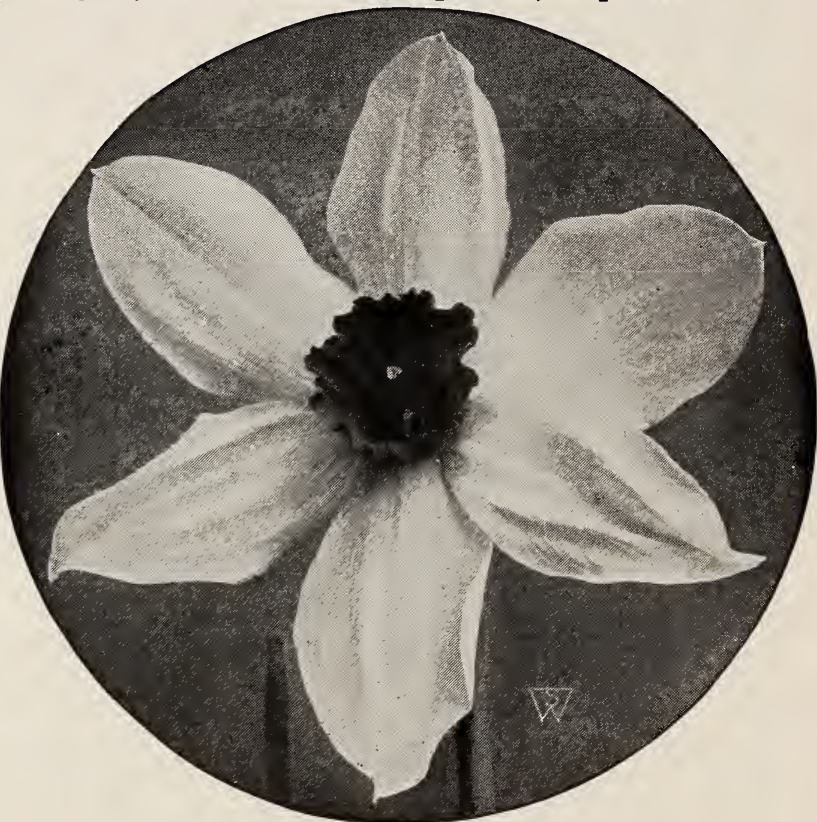

Medium Trumpet Narcissus, Lucifer

Medium Trumpets in Mixture. For naturalizing. Our mixture of the Medium Trumpets for natural plantations conMedium Trumpets in Mixture. tains a great many varieties which we do not list under separate headings and are excellent for this purpose. $\$ 4$ per $100, \$ 35$ per 1,000 . 


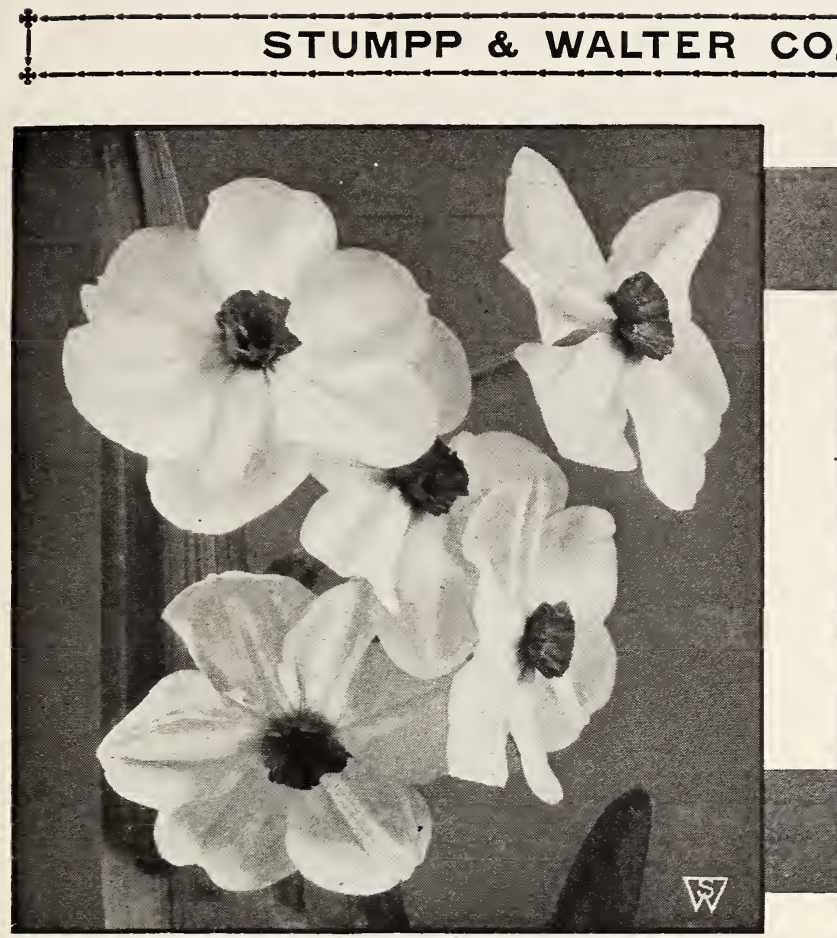

Narcissus Poetaz, Aspasia

\section{Narcissus Poetaz}

THE HARDY CLUSTER-FLOWERED POET'S NARCISSUS

Admiration. Perianth sulphur-yellow, with a sulphur-yellow eye rimmed scarlet-red; a beautiful new variety in this section. Height 20 inches. 15 cts. each, \$1.50 per doz., \$10 per 100 .

Alsace. Pure white, with yellow cup, having a slight reddish edge when nearly opened; broad large flower. usually three to a stem. 15 cts. each, $\$ 1.25$ per doz., $\$ 8$ per $100, \$ 75$ per 1,000 .

Aspasia. C. Perianth pure white, with soft yellow eye; three or four flowers on a stem. A splendid variety for outdoor planting; very bright in color. Height 18 inches. 15 cts. each, $\$ 1.25$ per doz., \$8 per $100, \$ 75$ per 1,000 .

Elvira. C. A large flower of remarkable substance; perianth pure white with a yellow eve; three or four flowers, two or three stems to a bulb; strong grower and free flowering. Splendid for pots, pans, or garden culture. Height 24 inches. 10 cts. each, $\$ 1$ per doz., $\$ 7$ per $100, \$ 65$ per 1,000 .

Irene. D. Yellow perianth, with deep golden yellow cup; broad flowers borne seven to eight on a stem; three stems to a bulb. The largest yellow. 15 cts. each, $\$ 1.25$ per doz., \$8 per 100, \$75 per 1,000 .

Klondyke. Perianth even tone of pure bright yellow, with golden yellow eye. A variety of wonderful vigor and size, giving 5 to 6 flowers on a stem. Height I4 inches. 15 cts. each, $\$ 1.50$ per doz., $\$ 10$ per 100 .
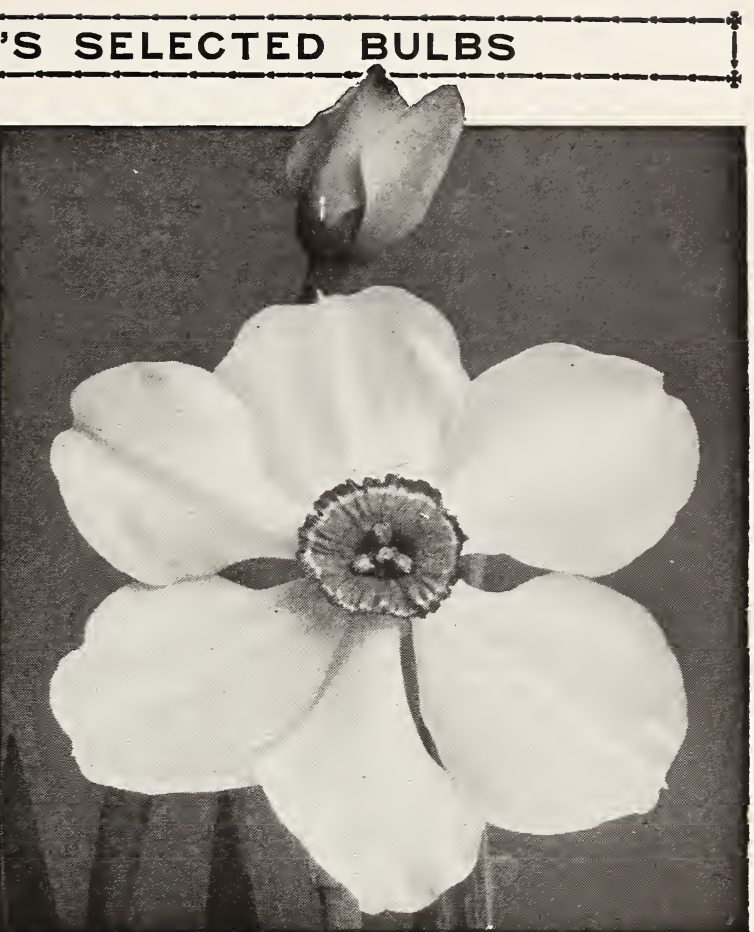

Narcissus Poeticus, King Edward VII

\section{The Poet's Narcissi}

\section{Narcissus poeticus}

This class of Narcissus, instead of having a trumpet or crown, has a small, wide-mouthed cup. They are very hardy, and are used in large numbers for naturalizing, their simplicity of form and delightful fragrance making them highly prized. Cassandra, Epic, King Edward VII, and Ornatus are used with excellent success for growing indoors in pots or pans, or gently forced into bloom for cutting purposes.

Cassandra. C. Broad, wide-spreading perianth of snowy white; very small, flat cup, deeply rimmed dark red; a flower of perfect shape and thick substance. A tall and vigorous grower. A fine Poet's Narcissus. Excellent for pot-culture. Height I8 inches. 20 cts. each, $\$ 2$ per doz., $\$ 15$ per 100.

Epic. Quite the best and largest of the new Poet's varieties. The white perianth is of large size, cup canary-yellow, rimmed bright red. Height I 7 inches. 15 cts. each, \$1.50 per doz., \$10 per 100.

King Edward VII. C. Round, white perianth, cup light yellow, margined deep red. A vigorous grower, excellent for pot culture. Height I 5 inches. $\$ 1$ per doz., $\$ 7$ per $100, \$ 65$ per 1,000 .

Ornatus (Improved Poeticus). C. Grand flower for cutting. Larger and more symmetrical than the old variety and considerably earlier. Pure white flowers, saffron cup, tinged rosy scarlet. Magnificent cut-flower. Height ${ }_{5}$ inches. Mother Bulbs, 75 cts. per doz., $\$ 4.50$ per $100, \$ 40$ per 1,000 .

Poeticus (Pheasant's Eye). E. The original late-flowering Pheasant's Eye variety so popular for gardens and naturalizing; pure white flowers with orange cup, edged with red. Height I5 inches. 60 cts. per doz., \$4 per 100, \$35 per 1,000 .

\section{Sweet-Scented Jonquils}

Very much prized for their deliciously scented golden flowers; perfectly hardy in gardens or naturalized, also admirably adapted to indoor culture in pots of soil.

We frequently receive orders for Jonquils when the Giant Trumpet Daffodils are desired. We ask our patrons to select varietal name in order to avoid the confusion caused thereby. The Jonquils listed below belong to a distinct type of the Narcissus family. The foliage is rush-leaved, and the flowers are borne in clusters of four or five on each stem, and should not be confused with the Giant and Medium Trumpet Daffodils in our list. We have decided to discard the common Single and Double Jonquils in favor of the following sorts.

Giant Campernelle rugulosus. Much larger and finer than the old favorite Campernelle Jonquils; a much freer bloomer and much more desirable, especially for forcing. Beautiful, single, yellow, star-shaped flowers, exquisitely imbricated, borne in clusters of four to six on a stem; delightfully fragrant. Also very hardy and valuable for outdoor planting. 80 cts. per doz., $\$ 5$ per 100, $\$ 45$ per 1,000 .

Rugulosus, Double. The double form of the large-flowering Campernelle Jonquil. Large, double, yellow flowers; very fragrant and much superior to the common Double Jonquil. Height 20 inches. 80 cts. per doz., \$5 per 100, \$45 per 1,000. 


\section{CHINESE SACRED LILY}

The "Shui Sin Far," or Water Fairy Flower, Joss Flower or Flower of the Gods. etc., as it is called by the celestials, is a variety of Narcissus, bearing in profusion chaste flowers of silvery white, with golden yellow cups. They are of exquisite beauty and entrancing perfume.

The bulbs, of large size and great vitality, are of luxuriant growth, producing several spikes of flowers; the incredibly short time required to bring bulbs into bloom (four to six weeks after planting) is one of the wonders of nature. You can almost see them grow, succeeding almost everywhere and with everybody. They do well in pots of earth, but are more novel and beautiful grown in shallow bowls of water, with enough fancy pebbles to prevent them from toppling over when in bloom. A dozen bulbs. started at intervals will give a succession of flowers throughout the winter. We have found that first-size bulbs, as generally sent out by other houses, do not flower satisfactorily, and we therefore offer only Mammoth and Jumbo sizes

Mammoth bulbs..........................

Each Doz. Ioo

Jumbo bulbs......................... $35 \quad 350 \quad 2750$

GLASS BOWLS, for one bulb of Chinese Lily, $3.5 \mathrm{cts}$. each, $\$ 3.50$ per doz.; for 6 bulbs, 50 cts. each, $\$ 5$ per doz.

PEBBLES. Carefully screened and selected. Per quart box, 20 cts., 2 boxes for $35 \mathrm{cts}$.

\section{JAPANESE LILIES (Cold Storage)}

Many of our patrons who have greenhouse facilities are desirous of planting bulbs of some of the varieties of Japanese Liliums during the summer months for flowering during the late autumn and Christmas time and to these we offer the following varieties: L. speciosum album, or the pink form, Magnificum (flowers in 5 months).

Per case L. speciosum album. White. 9- to I I-inch bulbs (50 per case)......\$25 o0 L. speciosum magnificum. Pink. 9. to I I-inch bulbs (50 per case).... 25 oo

\section{GROCUS}

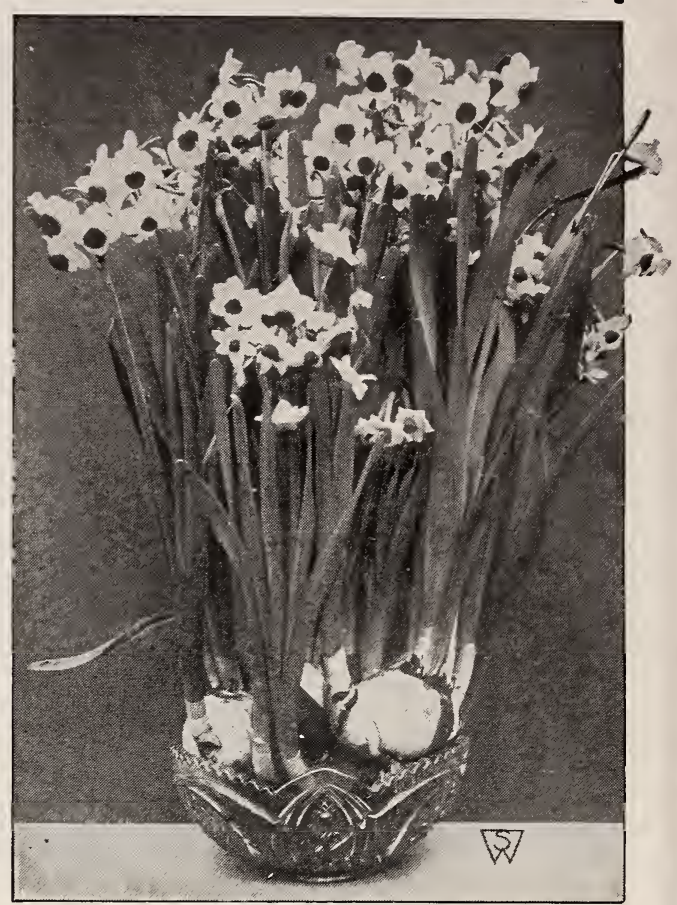

Chinese Sacred Lily

Crocuses, among the earliest bulbs to flower, are most effective when planted in masses on the lawn. or arranged in three or four rows of one color in the border. They are perfectly hardy, and may be left in the ground for three or four years after planting, without being disturbed. The best method is to scatter the bulbs about the lawn and use an ordinary garden dibble or "Slim Jim" trowel, inserting several bulbs in each spot. This makes a very pretty effect in early spring, and the foliage and tops may be safely cut along with the grass when the first mowing is made. They are very ornamental when flowered in pots of eight to ten bulbs to a 5-inch size. They will not flower if exposed to heat, nor must too severe forcing be attempted. After potting set bulbs in a cool cellar and water well. Leave them about six weeks until they are thorcughly rooted and then bring to the light of the conservatory or sunny window. Care should be taken to cover the bulbs about I inch, whether planted cutdcors or in pots, as planting too deep causes them not to flower.

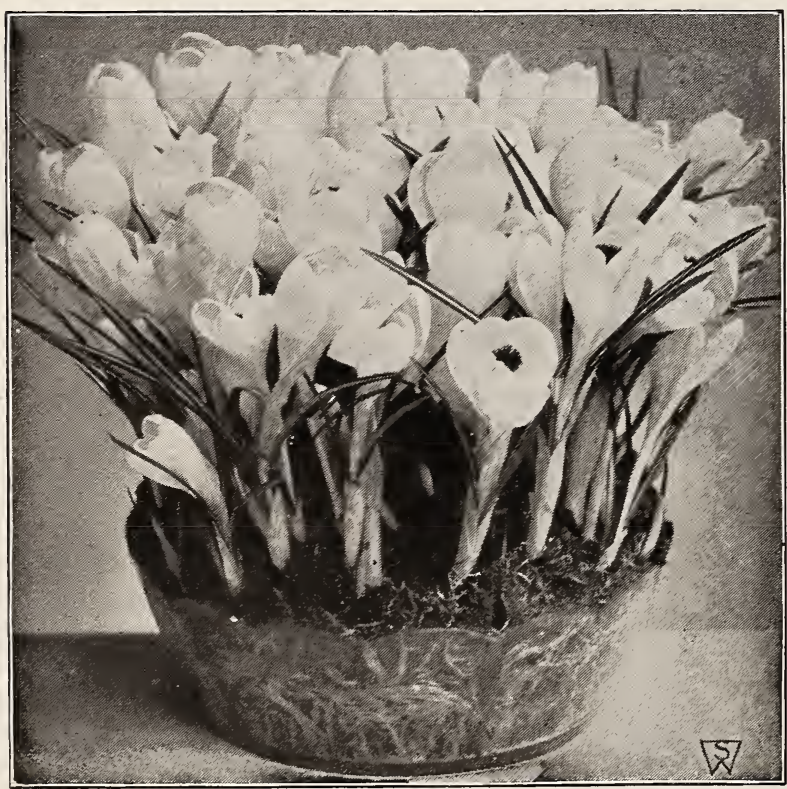

4 ny of the following, 40c. per doz., $\$ 2.50$ per $100, \$ 20$ per 1,000 Purpurea Grandiflora, Best dark blue.

Julia Culp. Large-flowering purple

Kathleen Parlow. Purest white, fine large flowers.

La Majestueuse. White, striped purple.

Mont Blanc. An old favorite; large; pure white.

Yellow Mammoth. The largest flowering sort of this color

S. \& W. Co.'s Special Mixture. A special mixture shades, 30 cts, per doz., $\$ 2$ per $100, \$ 18$ per 1,000 .

\section{SPIREA \\ November delivery}

This beautiful pot plant, usually grown by the florist for Easter, we are able to offer in three named varieties, in clumps suitable for growing in 6 -in pots.

Gladstone. Large spikes of pure white flowers, borne on strong stems 18 inches high.

Queen Alexandra. A popular variety on the order of Gladstone, but of a pale pink color.

Peach Blossom. A very lovely shade of peach-blossom pink. A very free-flowering variety.

Strong Clumps of any of the above 3 varieties, $\$ 1$ each, $\$ 10$ per doz., $\$ 75$ per 100 


\section{GIANT FREESIAS}

Without doubt the most sweetly scented flower grown; a single bloom permeates the living-room with its delicate perfume. Although they are quite popular and very easily raised, we would suggest the following treatment:

Procure the bulbs as early as possible, and plant them in successive batches from August to October, using from six to twenty-five bulbs for a single pan. The soil should be a mixture of loam, to which must be added leaf-mold and sand. The bulbs planted early, say August and September, may be placed outdoors in a sheltered spot until cold weather sets in; of course they must be regularly watered and kept growing all the time. In October, before frosts appear, the pots should be placed in frames, if possible, or near the window of an unheated room. Not before November must the young plants be brought to gentle heat, and if thus cared for they will flower perfectly in January. The foliage of the Freesias is very fine and slender and must be supported with light stakes placed around the outer edge of the pans. The glistening, pure white flowers are borne on long stems, and are very valuable for cutting.

\section{S. \& W. CO.'S IMPROVED PURITY}

Through painstaking effort our grower of Freesia Purity has maintained such a quality in our strain of this very desirable cut-flower by careful selection as to justify us in offering it as an improved strain.

Doz.
Monster bulbs....... 100

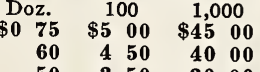

Mammoth bulbs

350

3000

\section{NEW FREESIAS}

Fischeri. A new variety which we believe will, when better known, white. $\$ 1$ per doz., $\$ 8$ per $100, \$ 75$ per 1,000 .

Fischer's Splendens. This comparatively new Freesia, instands in a distinct clarinator of Purity. stans. The flowers are equal in size to Purity and the plant just as vigorous. The stems are long and stiff,
bearing as many flowers as Purity, of a beautiful deep lavender color which seems to be well retained throughout the life of the flower. \$1 per doz., \$8 per 100, \$75 per 1,000.

Mrs. Robert Craig. A white throat, the veins of mauve running down each petal into the throat, without any yellow spots. The flowers are borne on strong, stiff stems, of large size and great beauty. \$2 per doz., \$15 per 100.

Dorothy Robins. A very deep lilac lavender, with large flowers urity shape. \$1.50 per doz., $\$ 10$ per 100 . Katherine Watkins. $\begin{aligned} & \text { A salmon-buff, very attractive; tall } \\ & \text { grower with stiff wiry stems. \$2 per }\end{aligned}$

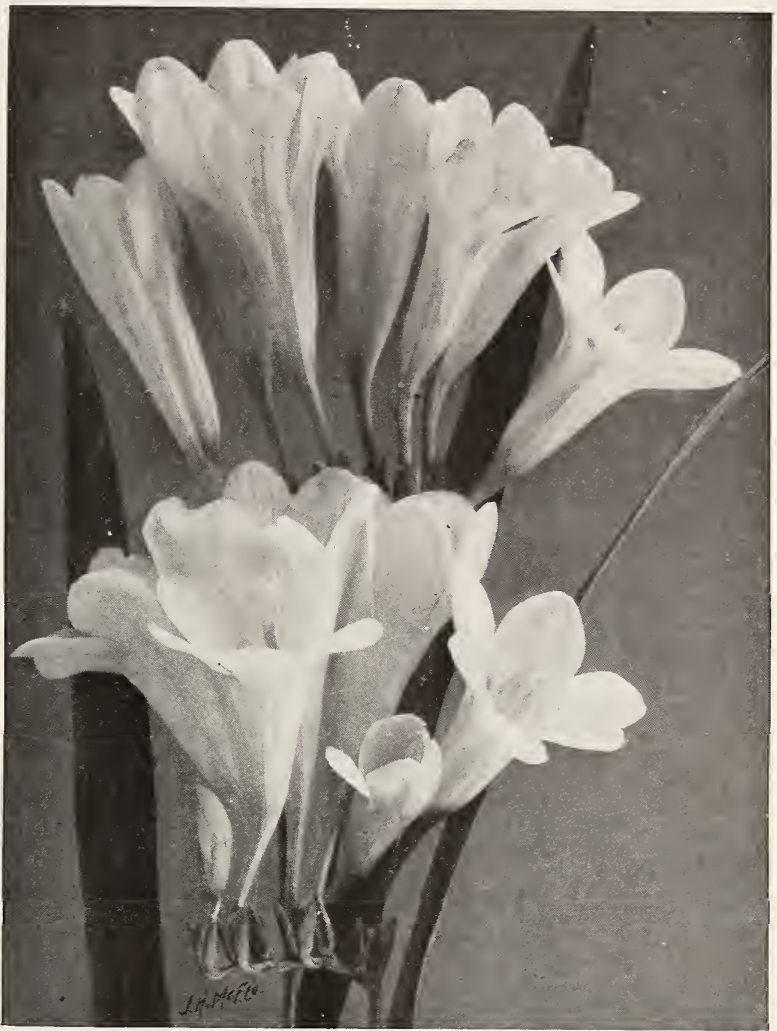

Freesia, S. \& W. Co.'s Improved Purity

General Pershing. One of the finest of the new colored white throat. A fine tall grower, very decorative. 80 cts. per doz., $\$ 6$ per $100, \$ 50$ per 1,000 .

Yellow Prince. A fine "new clear yellow, very free-flowering stems. \$1.50 per doz., \$10 per 100 .

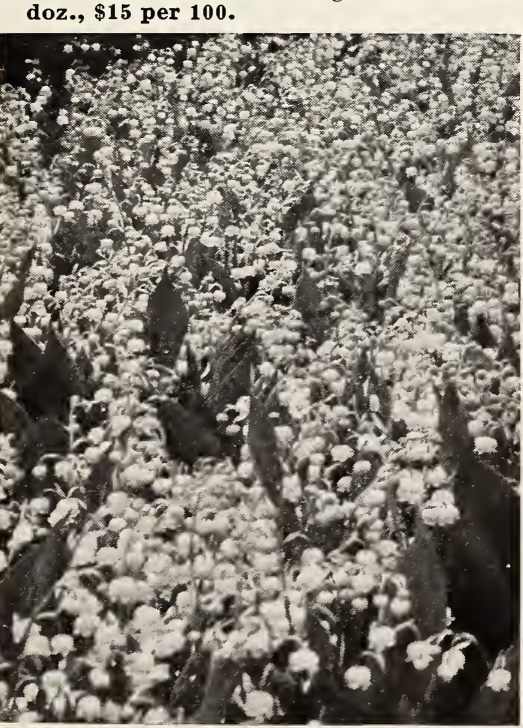

S. \& W. Co.'s Lily-of-the-Valley

\section{LILY-OF-THE-VALLEY}

We import especially from abroad each year large quantities of Lily-of-the-Valley in pip form as well as in clumps. If you are planning on making a bed of Lily-of-the-Valley in some shady place in your garden, you will find the planting of clumps quite the easiest method. We carry pips principally for those of our patrons who wish to grow them in pots or flats indoors.

\section{SUPERIOR LILY-OF-THE-VALLEY PIPS}

In judging the price of our Lily-of-the-Valley, please remember that the best is the cheapest. Our Valley is positively among the best. Is bought at open prices, with instructions for a selection of the best-developed pips. Our long experience and large importations have commanded this extra selection. Introduced a few years ago, it has now become famous, being forced very extensively by a large number of celebrated Lily-of-the-Valley growers. Our Lily-of-the-Valley produces strong spikes of flowers, about I 5 inches in height, bearing from twelve to twenty extra-large, pure white bells, which are delightfully fragrant. For forcing, these pips are the very best that can be planted. New crop, November delivery, 25 pips $\$ 1.50,100$ pips $\$ 5,1,000$ pips $\$ 45$.

\section{COLD STORAGE LILY-OF-THE-VALLEY}

250 pips $\$ 15,500$ pips $\$ 27.50,1,000$ pips $\$ 50$.

\section{LILY-OF-THE-VALLEY CLUMPS}

\section{For Outdoor Planting}

Our Lily-of-the-Valley Clumps are extra-selected, well grown and, if planted outdoors by the middle of April, will flower splendidly during May. If grown under the proper conditions, these clumps will increase rapidly, and every spring produce a profusion of dainty flowers. Extra-strong clumps, 50 cts. each, $\$ 5$ per doz., $\$ 35$ per 100. 


\section{HARDY LILIES}

We especially recommend deep planting, say, from 6 to 8 inches; varieties like Speciosums require at least 8 inches, with an ample amount of sand beneath the bulb to insure proper drainage. Cover the beds with leaves or litter during winter. Lilies thrive well in borders, formal gardens or shrubbery, and usually flower at a time when the shrubbery has ceased blooming, adding increased interest. The following varieties have proved to be sorts that may be planted in the fall or spring with excellent results. We frequently receive orders for Lilium candidum for spring delivery. This Lily arrives from France in September, and must be planted by November I.

Most Lily Bulbs, being of late maturity, do not arrive in our country until October and November, which is conceded to be the best time to plant. Where the ground is liable to freeze before late Lilies arrive, it should be mulched with leaves or manure.

\section{LILIUM CANDIDUM (Madonna Lily)}

Choice Northern-Grown. Arrive in August or September

The favorite Lily of the old-fashioned garden, produces strong, stiff stems, studded with a mass of pure, glistening white flowers, that enliven the perennial flower-garden or, for contrast with the beautiful green shrubs of the June garden, are unequaled, frequently growing $4^{1} / 2$ feet high.

Plant some bulbs during September and October and enjoy a big crop of flowers next June; or pot up, store in coldframe, and force for early winter in the greenhouse or conservatory. Our bulbs of this splendid Lily are grown in northern France, and are of the true thick-petaled variety, which is much superior in habit and flowering qualities to that of the cheap, loose, southerngrown bulbs.

First Size

Mammoth Bulbs

Jumbo Bulbs.

Each Doz. $\quad 100$

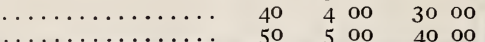

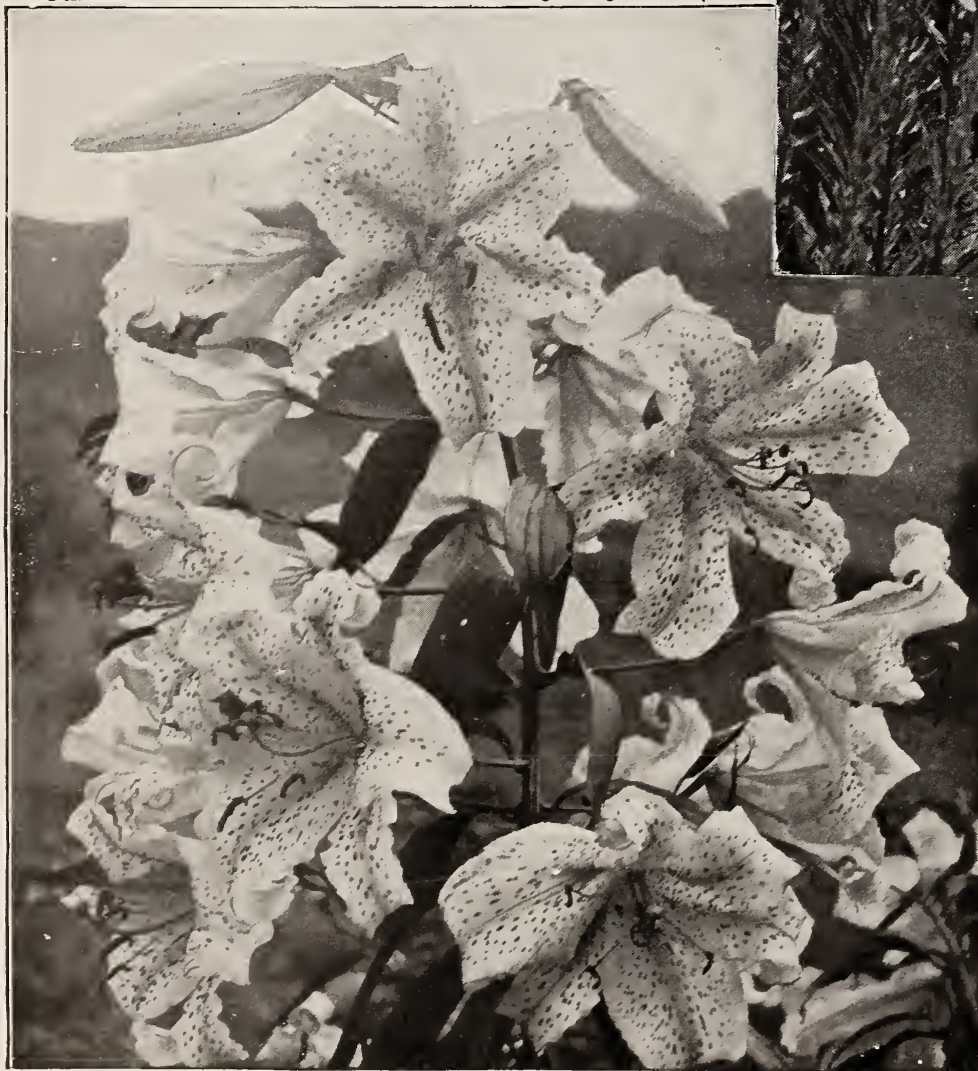

Lilium auratum (Golden-rayed Lily of Japan)

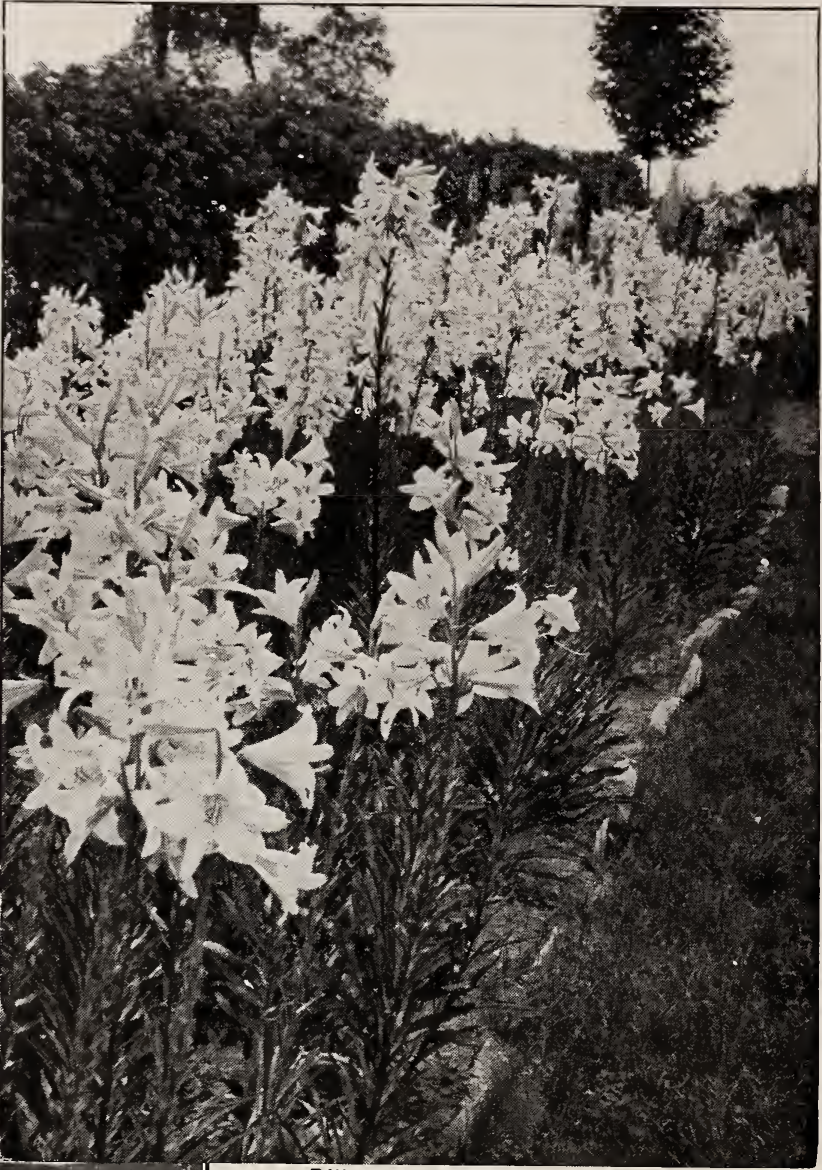

Lilium candidum

\section{LILIUM AURATUM}

(The Golden-Rayed Lily of Japan) November and December delivery

One of the finest and most popular of the hardy garden Lilies. It thrives best in locations where the lower portion of the plant will be partially sheltered from the hot sun, as among peonies or herbaceous plants in the hardy border, where groups of six to twelve of these Lilies produce a stately and magnificent effect. The flowers are pure white, thickly studded with crimson spots, while through the center of each petal runs a clear golden band. Fully expanded the flowers measure nearly a foot across, are produced abundantly from June to October, and possess a most delicious fragrance. 3 to 5 feet.

8 to 9 in. in circum..... \$o $35 \$ 350 \quad \$ 2500$

9 to II in. in circum.... $45 \quad 450 \quad 3500$

II to I3 in. in circum..... 65 . 6550

\section{LILIUM TENUIFOLIUM}

The lovely Coral Lily of Siberia. A great beauty. The brightest of all Lilies. Grows 20 inches high, with finely cut foliage, slender stems and beautifully shaded coral-red flowers. One ought to grow them by the dozen, they are so fine for cutting and making clumps for the lawn. Blooms very early. 30 cts. each, \$3 per doz., \$20 per 100 . 


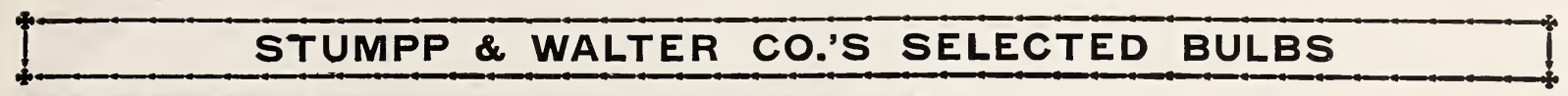

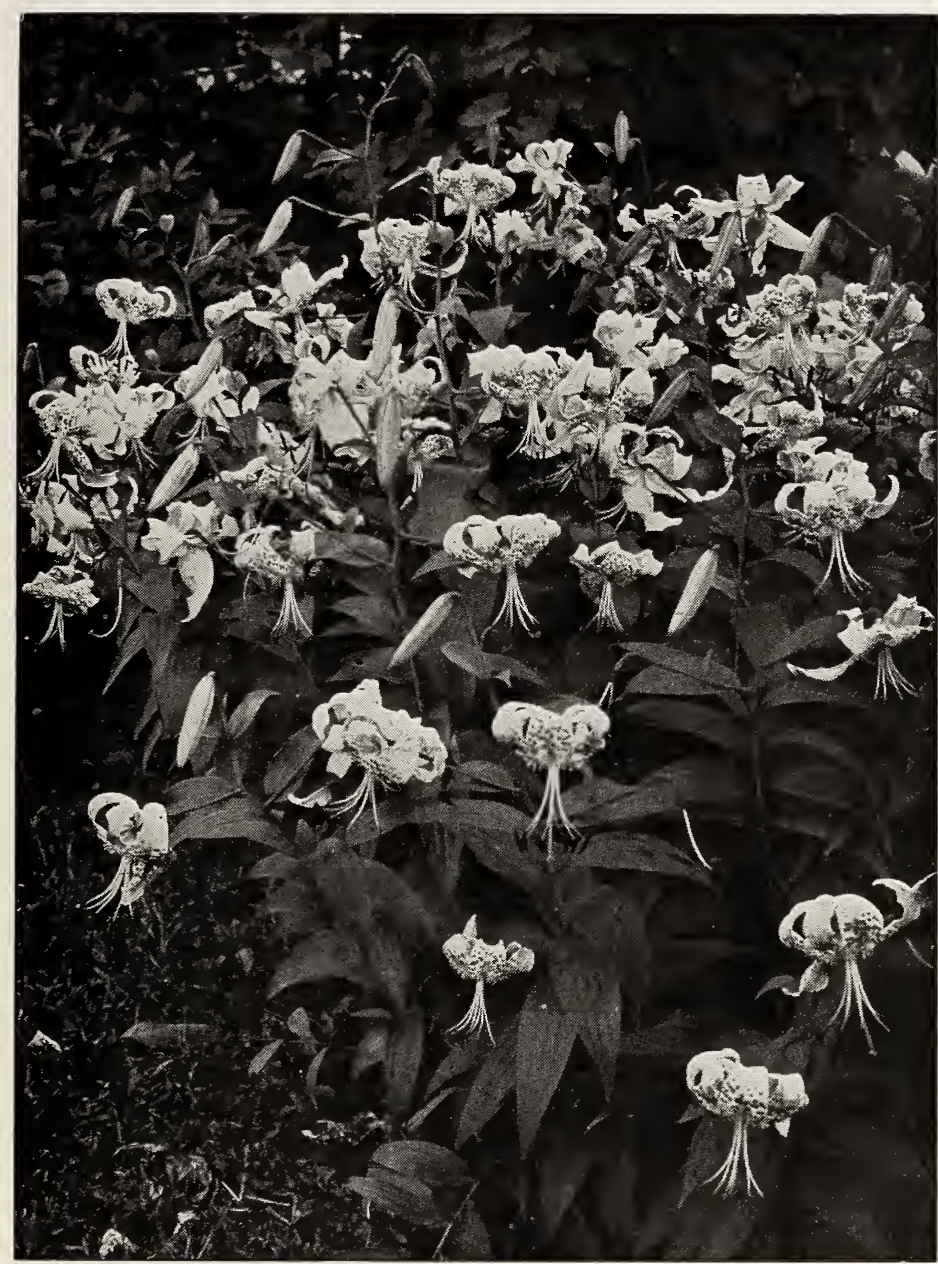

Lilium speciosum magnificum
HARDY LILIES, continued Lilium speciosum magnificum

(Oriental Orchids). November and December delivery

Words cannot describe the beauty of this variety. Frosted white, spotted, clouded and bordered with deep pinkish crimson. A much superior variety to the Roseum, Rubrum or Melpomene of the Speciosum type. For the border, among hardy plants or naturalized among rhododendrons, this is an equal favorite with the Lilium auratum offered on the previous page. Splendid for pot culture as well. Blooms outside during August.

8 to 9 in. in circum.

9 to I I in. in circum.

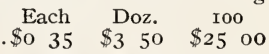

I I to I3 in. in circum. $\begin{array}{lllll}45 & 4 & 50 & 35 & 00 \\ 65 & 6 & 50 & 50 & 00\end{array}$

\section{Lilium speciosum album}

November and December delivery

The white Speciosum, which is usually grown with Magnificum and Lilium auratum, is a very dainty Lily. It flowers outside in the border or among rhododendrons at the same time as Auratum and Magnificum.

8 to 9 in. in circum. ...... \$o $35 \quad \begin{array}{lllll}\$ 3 & 50 & \$ 25 & \text { Do }\end{array}$ 9 to I I in. in circum. ....... $45 \quad 4 \quad 50 \quad 3500$ II to $I 3$ in. in circum.

$\begin{array}{lllll}45 & 4 & 50 & 35 & 00 \\ 65 & 6 & 50 & 50 & 00\end{array}$

\section{OTHER HARDY LILIES}

Suitable for Garden Culture

Hansonii. Under favorable conditions attains a height of 3 to 4 feet. Flowers reddish orange, eight to twelve in a cluster; petals thick and durable. $7 \dot{s}$ ets. each, $\$ 7.50$ per doz., $\$ 60$ per 100 .

Pardalinum. A California variety bearing twelve high; bright orange, spotted dark crimson. Flowers in July. 30 cts. each, \$3 per doz., \$20 per 100.

Superbum. In a collection of best plants of all countries, our native Superbum Lily would deserve a first place. In deep, rich soil it often grows 8 feet high, with twenty to thirty flowers. It is of the easiest culture, and may be grown as a wild flower in any swampy or rough part of a place where the grass is not mown. Extra-selected bulbs. 25 cts. each, \$2.50 per doz., \$I5 per IOO.

Tigrinum splendens. The finest type of the quaint and much-loved Tiger Lily. Large, selected bulbs, 25 cts. each, \$2.50 per doz., \$I 5 per Ioo.

Tigrinum splendens, Double. The double form of the above. 25 cts. each, $\$ 2.50$ per doz., \$I5 per Ioo.

\section{LILY BULBS FOR INDOOR GROWING}

\section{CALLA LILIES}

These like a stiff, clayey soil with a small quantity of shredded cow-manure. Bulbs should be set with the crown, or top, protruding just above the surface. When in growing condition, warm water given several times during the week will hasten the flowering period and increase the number of blooms. When using the large-sized bulbs, plant but one in a pot; smaller ones, two. We call especial attention to the Yellow Calla, which is one of the grandest varieties in cultivation, and most valuable for house or conservatory decoration. See the description opposite. Plant Callas indoors only in the fall of the year.

WHITE CALLA LILY-

Jumbo size. . . . . . . . .

\begin{tabular}{rrrr} 
Each & \multicolumn{2}{c}{ Doz. } & \multicolumn{2}{c}{ I00 } \\
$\$ 0$ & 50 & $\$ 500$ & $\$ 40$ 00 \\
40 & 4 & 00 & 3000 \\
25 & 2 & 50 & 2000
\end{tabular}

First size.

TELLOW CALLA LILY. A grand novelty-one that should be planted extensively. The deep golden yellow flowers are truly magnificent and produced in abundance. The green foliage is spotted creamy white, which adds to its beauty.

First-size bulbs.

$$
\begin{aligned}
& \begin{array}{cc}
\text { Each Doz. } & 100 \\
\$ 0 & 40
\end{array} \\
& \begin{array}{llll}
50 & 5 & 00 & 40
\end{array}
\end{aligned}
$$

\section{EASTER LILIES}

We offer three types of the Longiflorum Lily usually grown by the florist. Of the three types we recommend Lilium formosum as the best for private conservatory growing.

LILIUM HARRISII- Each Doz. Ioo

These bulbs usually arrive from Bermuda in $\$$ 6o $\$ 6$ oo $\$ 4500$ July. I oo Io $00 \quad 9000$

L. LONGIFLORUM FORMOSUM-

We have contracted for and expect some of each of the following sizes to arrive about

Sept. I. 7 to 0 inches in circumference... $50 \quad 500 \quad 4000$

8 to ro inches in circumference.
8 to 70 inches in circumference.

9 to Io inches in circumference.

Io to 12 inches in circumference.

II to 13 inches in circumference.

L. LONGIFLORUM GIGANTEUM-

We have contracted for and expect some of each of the following sizes to arrive October or early November.

7 to 9 inches in circumference.

8 to 9 inches in circumference.

9 to Io inches in circumference.

Io to 12 inches in circumference.

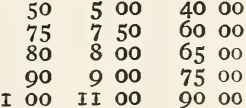

$\begin{array}{lllll}40 & 400 \quad 3000\end{array}$

$45 \quad 450 \quad 3500$

$50 \quad 5$ oo 40 oo

$55 \quad 550 \quad 4500$

$75750 \quad 6000$ 


\section{Miscellaneous List of Bulbs}

\begin{abstract}
AMARYLLIS
Giant-flowering Vittata Hybrids. Conceded to be the most noble and magnificent section of the Amaryllidaceæ. It would require a
great amount of space to offer them with descriptions of the several great amount of space to offer them with descriptions of the several
representative types, so we confine ourselves to listing in two general classes: Red ground, variegated with white; white ground, variegated with red. The red varies in tones from a brilliant fiery color to crimson; the variegation is sometimes a broad blaze of white in the center of each petal; again, the ground-color is white, abundantly streaked with red or crimson. The flower-spikes are from I to 3 feet high, the foliage long and graceful. Flowers, borne in clusters, are often 8 inches across. Extra-strong bulbs, $\$ 2$ each. $\$ 20$ per doz.
\end{abstract}

\section{ANEMONES (Windflower)}

These popular flowers of French origin are exceedingly useful, as a decorative plant for house or garden, and fine for cutting. If planted outdoors in the fall they must be well protected with leaves or other litter; they may also be planted in the spring in well-drained soil, and will flower during the summer, starting in May. When planted in pots, place twelve or more in a cluster and store away, if possible, in a coldframe until March I 5; if carefully watered, when brought into the house they will flower abundantly. Height 8 inches.

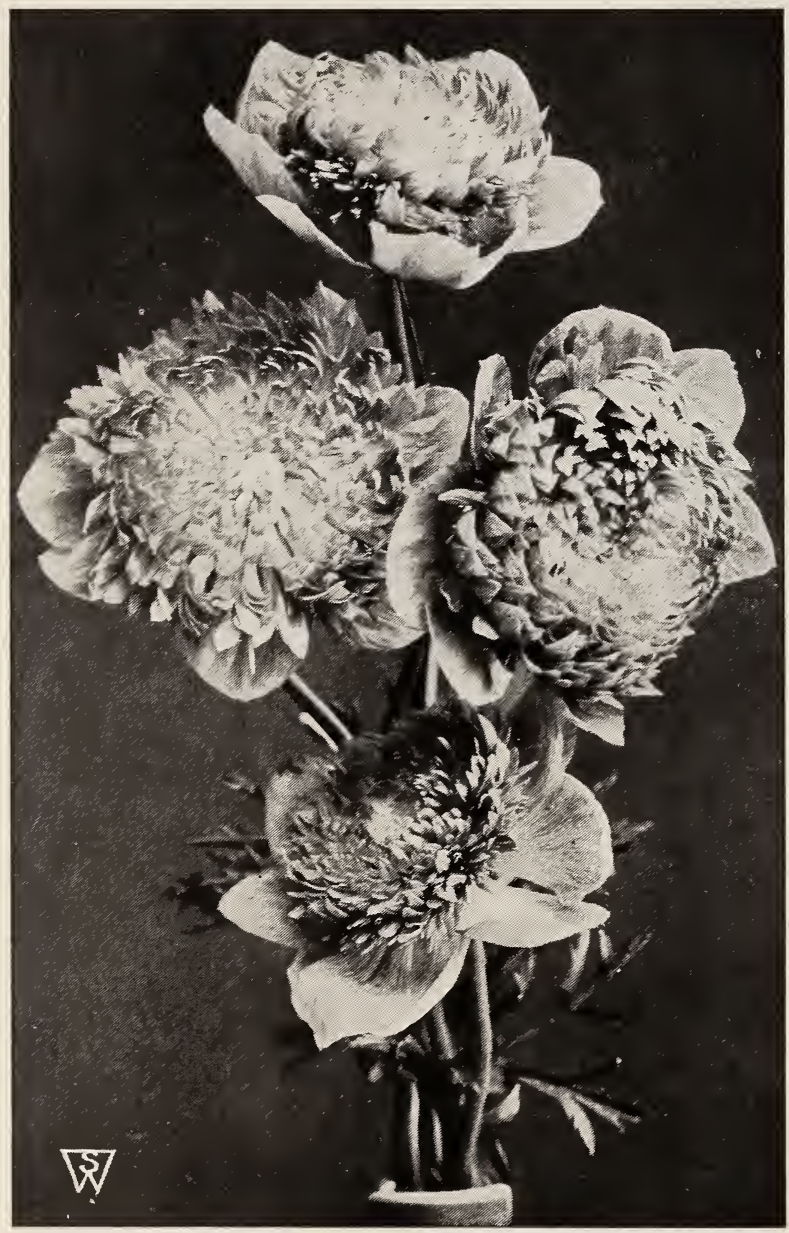

Anemone, St. Brigid
ANEMONES, continued

Excelsior Mixture. We consider this the finest strain of singleflowering Anemones as yet raised. The plants are taller in growth than the St. Brigid and more single. They contain many fine shades of scarlet. \$I per doz., $\$ 7.50$ per Ioo.

St. Brigid. A new and greatly improved race of Irish production, bearing magnificent flowers, double, semi-double and single, 3 to 5 inches across, and of the richest as well as the daintiest colors, markings and blendings, all having a distinct, dark base. They have long stems; very graceful flowers for vases. When grown indoors and forced gently the flowers are lovely. \$I per doz., \$7.50 per Ioo.

\section{CHIONODOXA (Glory-of-the-Snow)}

An early-flowering spring bulb for borders or rockery. Produces flower-spikes bearing ten to fifteen scilla-like flowers. Perfectly hardy and should be planted close together for effect.

Luciliæ. Deep blue, with a white center. Selected mother bulbs, 60 cts. per doz., $\$ 4$ per I oo, $\$ 35$ per I,0oo.

Luciliæ alba. Beautiful white form of the above. \$I per doz., $\$ 8$ per Ioo, $\$ 75$ per I, 00o.

Sardensis. The gentian-blue, very striking. Selected mother bulbs, 60 cts. per doz., $\$ 4$ per I0o, $\$ 35$ per I, 000 .

\section{ERANTHIS HYEMALIS (Winter Aconite)}

Early in spring the golden blossoms look charming, resting on an emerald-green cushion of leaves, and forming a striking contrast to the snowdrops, scillas, and chionodoxas. The foliage remains long after the flowers, making the plant especially valuable in moist situations, such as under trees, which the Winter Aconite enjoys, and where few other flowering plants will thrive. 3 to 8 inches high 50 cts. per doz., $\$ 3.50$ per I oo, $\$ 30$ per I, 000 .

\section{FRITILLARIA IMPERIALIS}

\section{(Crown Imperials)}

Well-known hardy border plants, bearing clusters of immense, pendent bell-shaped flowers, surmounted with a tuft of green leaves. They are excellent for hardy borders and may be left undisturbed for years.

Aurora. Red......

Crown on Crown. Several whorls of red

flowers, one above the other

Double Red. Deep red

Double Yellow. Rich yellow.

$$
\begin{array}{rrrrr}
\text { Each } & \multicolumn{2}{c}{\text { Doz. }} & \multicolumn{2}{c}{100} \\
\text { \$o } 25 & \$ 2 & 50 & \$ 20 & 00 \\
25 & 2 & 50 & 20 & 00 \\
35 & 3 & 50 & 25 & 00 \\
35 & 3 & 50 & 25 & 00
\end{array}
$$

\section{FRITILLARIA MELEAGRIS}

Singular, dwarf, spring-flowering plants, bearing large, pendent bell-shaped flowers of various colors, in yellow, white, black, purple, striped and splashed and checkered in the most curious way. They are invaluable for pot culture, and exceedingly pretty when grown in large groups in the garden border or wild garden in a dry situation. Alba. White. $75 \mathrm{cts}$. per doz., $\$ 6$ per $100, \$ 50$ per $\mathrm{r}, 000$. Calypso. Purple. $75 \mathrm{cts}$. per doz., $\$ 6$ per I $00, \$ 50$ per I, 000 . Mixed. Select mixtures. 65 cts. per doz., $\$ 5$ per Ioo, $\$ 45$ per I, 000 .

\section{GRAPE HYACINTHS}

Very beautiful little flowers for planting in masses, either in shade or where exposed to the sun. When planted out in herbaceous borders, where they can be left undisturbed, they do exceedingly well, each year adding to their already profuse-blooming qualities. Bloom outdoors during May. They are also excellent for pot culture.

Heavenly Blue. This variety is the largest and best of the Grape Hyacinths. The bells are large and form a fine truss. Splendid effects are produced by massing in the garden or border. 60 cts. per doz., \$4 per Ioo, \$35 per I, 000.

Album. A very beautiful white form of the above and excellent to use for contrasting with Heavenly Blue. $60 \mathrm{cts}$. per doz., $\$ 4$ per I00, \$35 per I,000.

Blushing Bride. A very delicate pink with bright carmine blotch in the throat. 80 cts. per doz., $\$ 7$ per Ioo, $\$ 60$ per $\mathrm{I}, 000$

Peach Blossom. A very lovely shade of soft pink on the order of the Killarney rose. $80 \mathrm{cts}$. per doz., \$7 per I00, $\$ 60$ per I,000. 


\section{Miscellaneous List of Bulbs, continued}

\section{IXIAS}

The Ixia is a beautiful little winter-flowering bulbs, with long, lender, graceful spikes of bloom. The colors are rich, varied and beautiful, the center always differing in color from the other parts of the flower, so that the blossoms, expanding in the sun's rays, present a picture of gorgeous beauty. Very desirable for pots. Doz. Ioo Althæa. Large; white, with purplish carmine eye..... \$o $85 \quad \$ 6$ oo Aurantiaca major. Golden yellow, with large dark Craterioides major. Bright scarlet; very early; forces well.

Hubert. Deep maroon; very beautiful.

Mozart. Pink-lovely color.

Finest Mixed

\section{OXALIS}

An unrivaled winter-flowering pot-plant of the easiest culture, succeeding with everybody

This is one of the finest flowering plants for pot culture that we have ever seen; it is such a strong, luxuriant grower that five or six bulbs will be sufficient for a 6- or 8-inch pot. Place in a dark, cool position for several days to root thoroughly, and remove to a sunny situation in the window or conservatory in a temperature of about 60 degrees Fahr., and the great profusion of bloom produced in uninterrupted abundance for weeks will astonish and delight you.

Large-Flowering. We have a very fine strain of these Oxalis. Flowers are large, and they may be had in blossom, by successional plantings, from October until May. We have four colors-Yellow, Pink, White, and Lavender. 50 cts. per doz., \$3.50 per Ioo.

Bermuda Buttercup. Bright sunny yellow. 50 cts. per doz., $\$ 3.50$ per Ioo.

\section{RANUNCULUS}

The bulbs of Ranunculus resemble tiny clumps of dahlia roots. They look as much like spiders as anything. The flowers are extremely double, almost globular, regular in outline, often exceed 2 inches in diameter, and are to be had in all the colors except blue. The colors are bright, clear, and pure.

\section{CULTURAL DIRECTIONS}

Here are cultural directions by a man who has scored a success with them: "The roots usually arrive in October and are better if placed in the soil as soon as time will permit, although it will not harm them seriously if they are packed away in dry sand in a cool shed or cellar for some weeks. Pots, pans, flats, or benches may be used for growing Ranunculuses, but flats and benches give me the most satisfactory results. I have had good success by using flats 5 inches deep, planting the roots in late October, then placing in coldframes and covering with dry leaves on the approach of severe weather, protecting sufficiently to exclude frost, and housing the flats from the early part of February onward.

The compost used is light but tolerably rich, consisting of three parts loam, one part leaf-mold, one part old, well-decayed manure pảssed through a $1 / 2$-inch screen, and a generous dash of sharp sand. The flats should be well drained.

"For those growing a limited number, flats are to be recommended, but where bench space will permit, the roots can be planted out 4 to 5 inches apart each way.

"A violet temperature, 40 to 45 degrees at night, is just what Ranunculuses need, and, as they do not make a heavy growth which shades the violets appre-, ciably and do not impoverish the soil, this method of culture can with confidence be recommended.

"In a poorly drained bed or bench many Ranunculus roots will rot: but given suitable porosity to allow water to pass away readily, any florist can grow given suitable porosity to allow water to pass away readily, any florist can grow
these pretty spring flowers creditably. Strong fumigation where they are growing should be avoided. Occasionally groen aphis may attack the foliage, but light fumigation will readily control this. If the plants turn yellow it is a sign of overwatering, poor drainage, too high temperature, or a combination sign of over

French Mixed. We also offer a mixture of all colors of the French Ranunculus at 75 cts. per doz., $\$ 5$ per Ioo, $\$ 45$ per I, ooo.

Turban. We offer five distinct colors of this splendid type.

Hercules. Pure white.

Primrose. Pale primrose.

Romano. Fine scarlet.

Source d'Or. Yellow, brownish flaked.

$\$ 1$ per doz., $\$ 7$ per $100, \$ 65$ per 1,000

\section{SNOWDROPS}

These elegant little flowers, the first to open in spring, should be found in every garden, not only because they are the earliest spring flowers, but because they are the loveliest. The Snowdrop thrives in almost any situation or soil, and should be planted as early in the autumn as possible, as they suffer much if left long out of the ground.

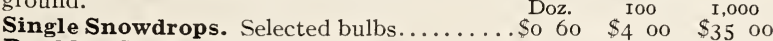
Double. Selected bulbs.

$\begin{array}{llll}4 & 00 & \$ 35 & 00\end{array}$

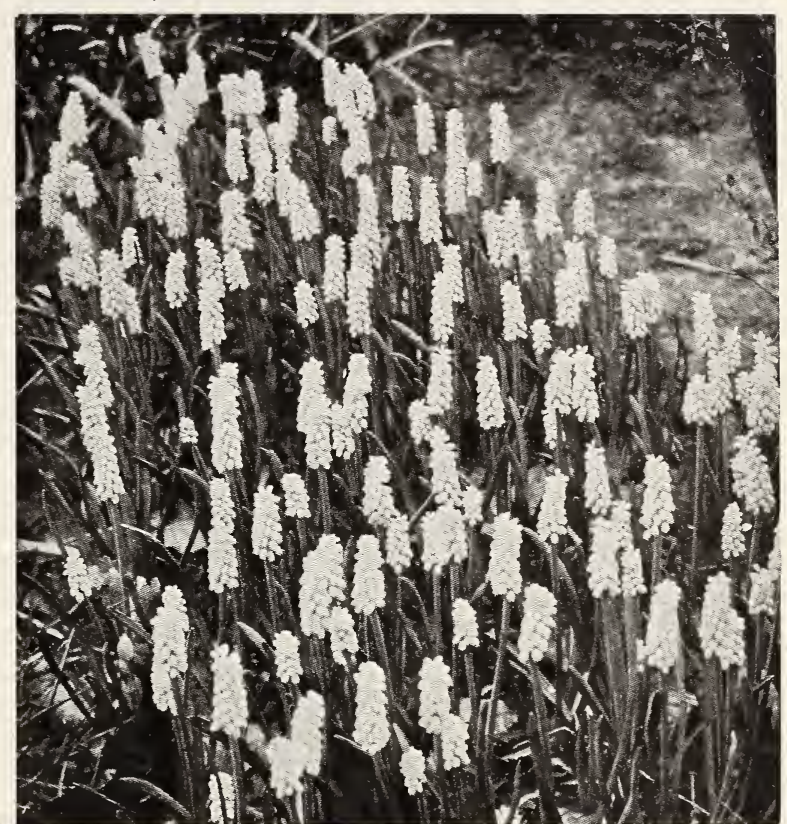

Bed of Grape Hyacinths (See page 28)

SCILLAS (Wood Hyacinth, Siberian

Campanulata (Wood Hyacinth)

Bears spikes, I 5 inches high, of bell-like flowers, during early May. Plant 5 or 6 inches deep in shady situations. Very effective for borders; will grow under fir or pine trees.

Alba maxima. Clear white, with very fine, large bells. 75 cts. per doz. \$5 per Ioo, \$45 per I, Ooo.

Blue Queen. Erect spikes of porcelain-blue flowers; strong grower. 75 cts. per doz., $\$ 5$ per Ioo, $\$ 45$ per I, 000 .

Excelsior. Bright deep blue, with large bells. 75 cts. per doz., $\$_{5}$ per I00, $\$ 45$ per I,000.

Rose Queen. Bells of soft lilac-rose; very pretty. 75 cts. per doz. $\$ 5$ per I00, \$45 per I,000.

\section{Scilla sibirica (Siberian Squill)}

Spikes 3 to 4 inches high, of small, drooping, bell-like flowers. Fine for massing in borders or naturalizing. Plant 3 to 4 inches deep. Blooms in April.

Blue. Splendid for massing. Jumbo bulbs, 75 cts. per doz., $\$ 5$ per IOo, $\$ 45$ per I,000.

White. A variety sometimes used for interspersing with the blue sorts. 75 cts. per doz., $\$ 5$ per Ioo, $\$ 45$ per I, 0oo.

\section{TRILLIUM GRANDIFLORUM}

\section{(Great American Wood Lily)}

This is one of the most beautiful American plants, perfectly hardy, growing and flowering profusely in partially shady nooks about the lawn, under trees, etc. The flowers are large, of the finest white, changing in a few days to soft rose; if grown several in a pot, it makes one of the best white winter flowers. \$3 per doz., \$20 per Ioo.

\section{TRITELEIA (Spring Star Flower)}

Uniflora violacea. A perfect little gem for pot culture. It flowers in the early spring months. The bulbs are small and several should be grown in a pot. It grows about 6 to 8 inches high, each bulb producing several pretty star-shaped flowers of a delicate violetblue which emit the perfume of primroses. They are perfectly hardy, and when grown in quantities in a sunny border or used for edging, they are very effective. $60 \mathrm{cts}$. per doz., \$4 per I00, \$35 per I,000. 


\section{BEAUTIFUL BULBOUS IRISES}

Few flowers are equal in merit to the Iris, in its many forms and gorgeous colorings. The Irises offered on this page are bulbs and are grown just like the daffodil or tulip. The Dutch Iris in this latitude flowers during May, the Spanish in early June. Iris tingitana is usually grown indoors in pots. Bulbs do best if planted in October, and also seem to do better if protected with a slight covering during winter. beneficial.

\section{SPANISH IRIS (Iris hispanica)}

These exquisite and dainty flowers may be justly termed the "poor man's orchid," as the colorings and markings are scarcely surpassed by that noble genus. The flowers are exceedingly graceful, of large size, frequently 4 to 5 inches across, and are borne on stems 24 inches tall. Few, if any, of the Irises lend themselves to more artistic arrangement as a cut-flower for the drawing-room or the dinner-table.

They may be planted in pots and stored in coldframes over winter, and forced into bloom during March. They are seen to the best advantage if arranged in masses of the different colors, all of which combine splendidly, in borders or beds. Plant bulbs 3 to 4 inches deep, and the same distance apart. Sharp builders' sand, to the depth of I inch beneath base of the bulbs will amply repay by more luxuriant spikes and larger flowers. A situation well open to the sun suits them best, and, like all bulbous Irises offered, a slight mulch will prove

Belle Chinoise. Bright sunny yellow.

Cajanus. Rich golden yellow.

Heavenly Blue. Deep sky-blue.

Hercules. Beautiful bronze.

King of the Blues. Deep dark blue.

King of the Whites. Large; pure white.

Queen Wilhelmina. Large; pure white.

Selected bulbs, any of the above varieties, $60 \mathrm{cts}$. per doz., $\$ 4.50$ per $100, \$ 40$ per 1,000 .

\section{DUTCH IRIS (Iris hollandica)}

\section{New Early-Flowering Dutch Iris}

This race may be best described as a giant strain of the early-flowering Spanish Iris. The foliage is broader and of a rich, glaucous green and the flowers are rich in their colorings. They flower about two weeks earlier than the Spanish Iris, and require the same cultural treatment. Like all bulbous Iris offered, they are better for a covering of leaves or litter as a protection.

Anton Mauve. A uniform soft blue; very large and substantial flower.

Brijet. Porcelain-blue, shaded grayish lilac.

Der Kinderen. Bright blue standards with yellow falls.

Franz Hals. Pale blue, with creamy yellow falls and large orange spot.

Hart Nibbrig. Brilliant clear blue. Considered one of the finest of this beautiful family.

Hartz. Standards purple-blue, flaked lilac; falls grayish lilac.

Hobbema. White, faintly tinged blue, with white standards.

Van Der Venne. Lilac and creamy white.

Selected bulbs, any of the above varieties, $85 \mathrm{cts}$. per doz., \$6 per 100, \$55 per 1,000 .

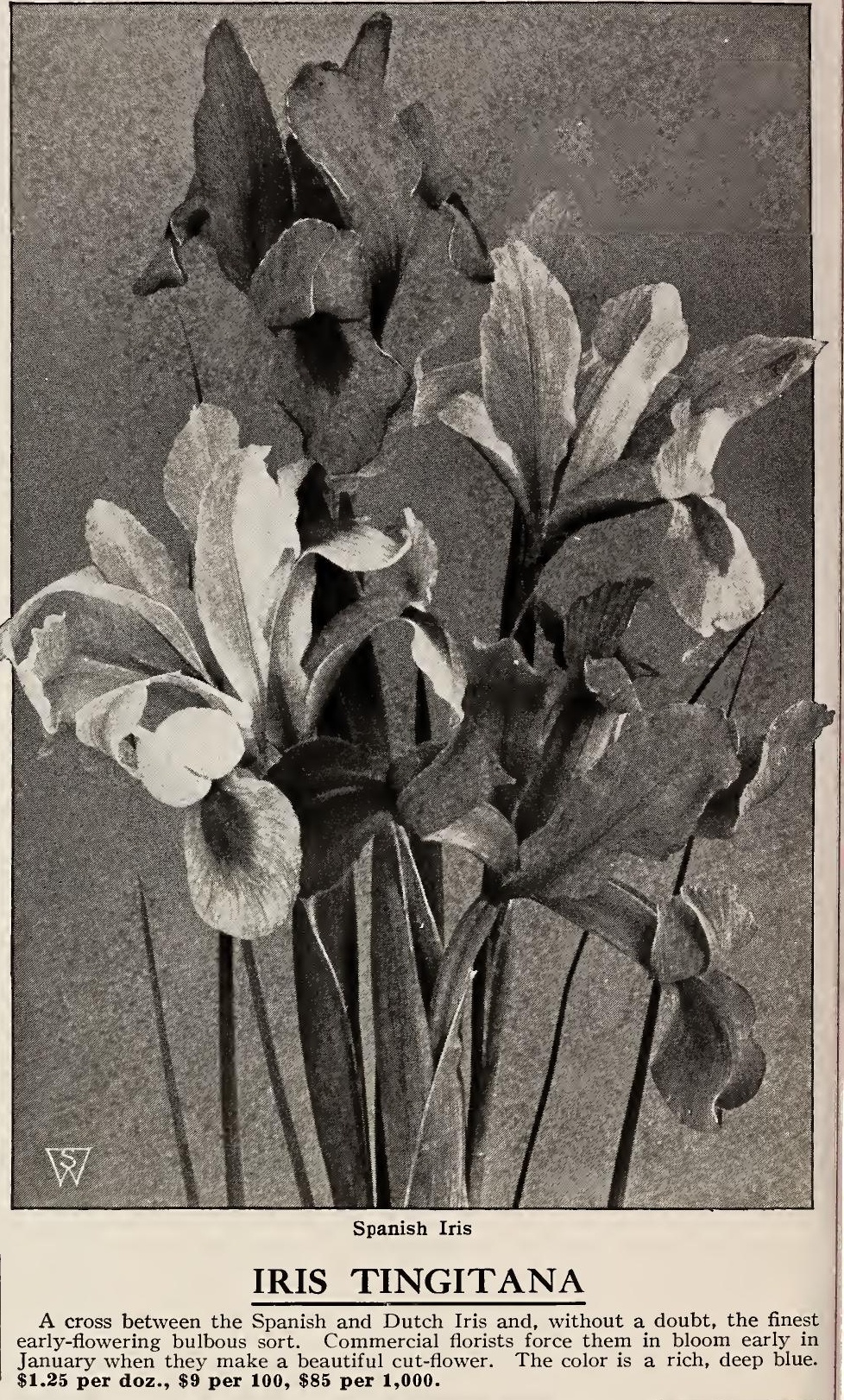

The two varieties of Iris Bulbs offered on this page most suitable for outdoor planting for cutflowers are the Spanish and Dutch. It is advisable to plant both, as the Dutch come into flower most seasons about ten days earlier. 


\section{ORDER SHEET}

Dutch, French and Japanese Bulbs . Advance Bulb Catalogue, 1923

We. Stumpp \& Walter Co., give no warranty, express or implied. as to description, quality, productiveness or any other matter of any
seeds, bulbs, or plants we send out, and will not be responsible for the crop.

\section{STUMPP \& WALTER CO.} 30 and 32 Barclay St., New York

\section{Name. \\ P. O. Box, Street \\ or Rural Delivery}

Post Office

County State

Station or Express Office

Send by

Only if different from Post Office

Superintendent or Gardener.

State if wanted by Mail, Express or Freight

That we may enter for Catalogues

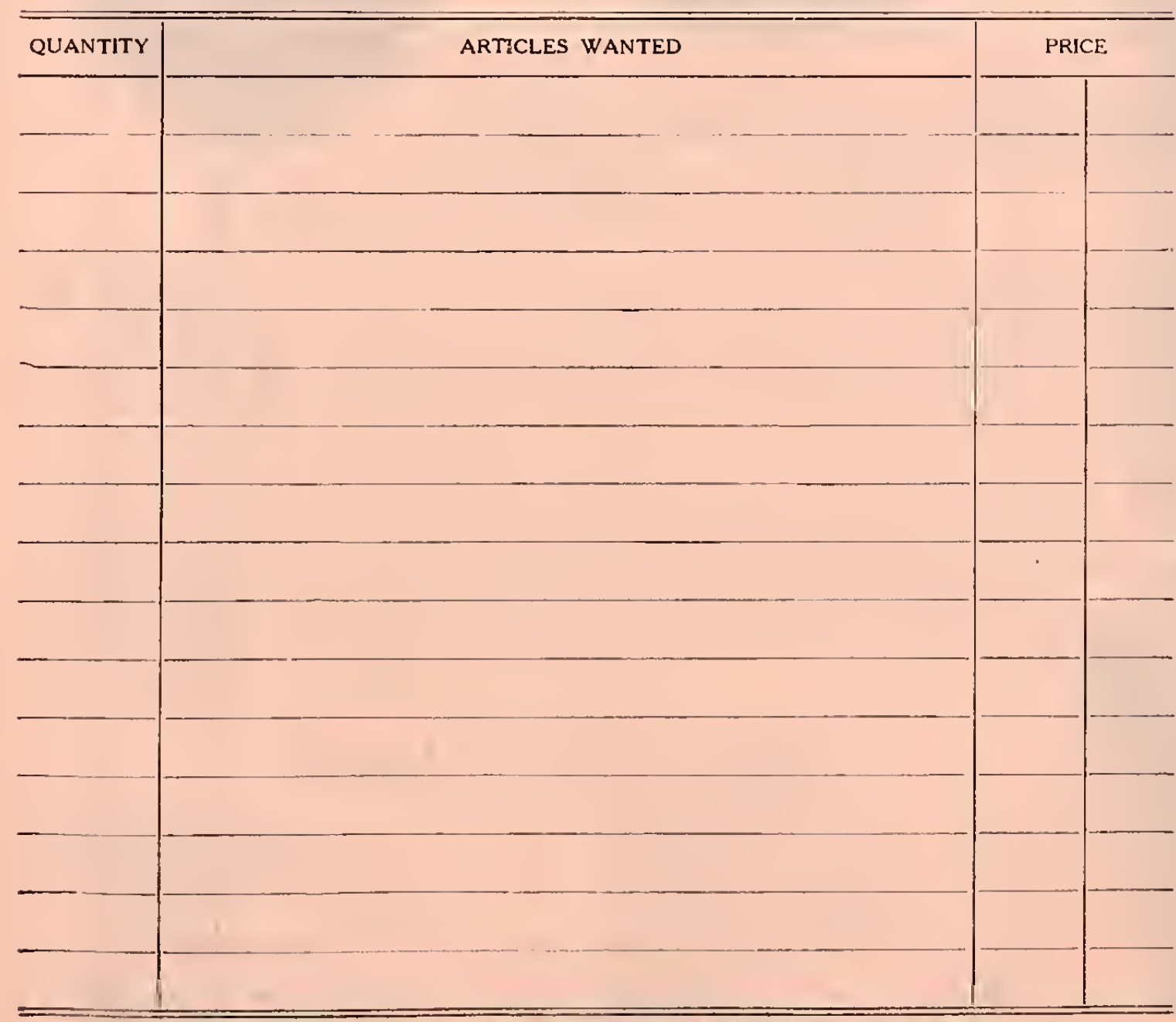

PLEASE BE SURE TO FILL IN YOUR NAME AND ADDRESS ABOVE
Date__ 1923 ENCLOSED

Advance Bulb

Offering

for Orders up

to July 15 th

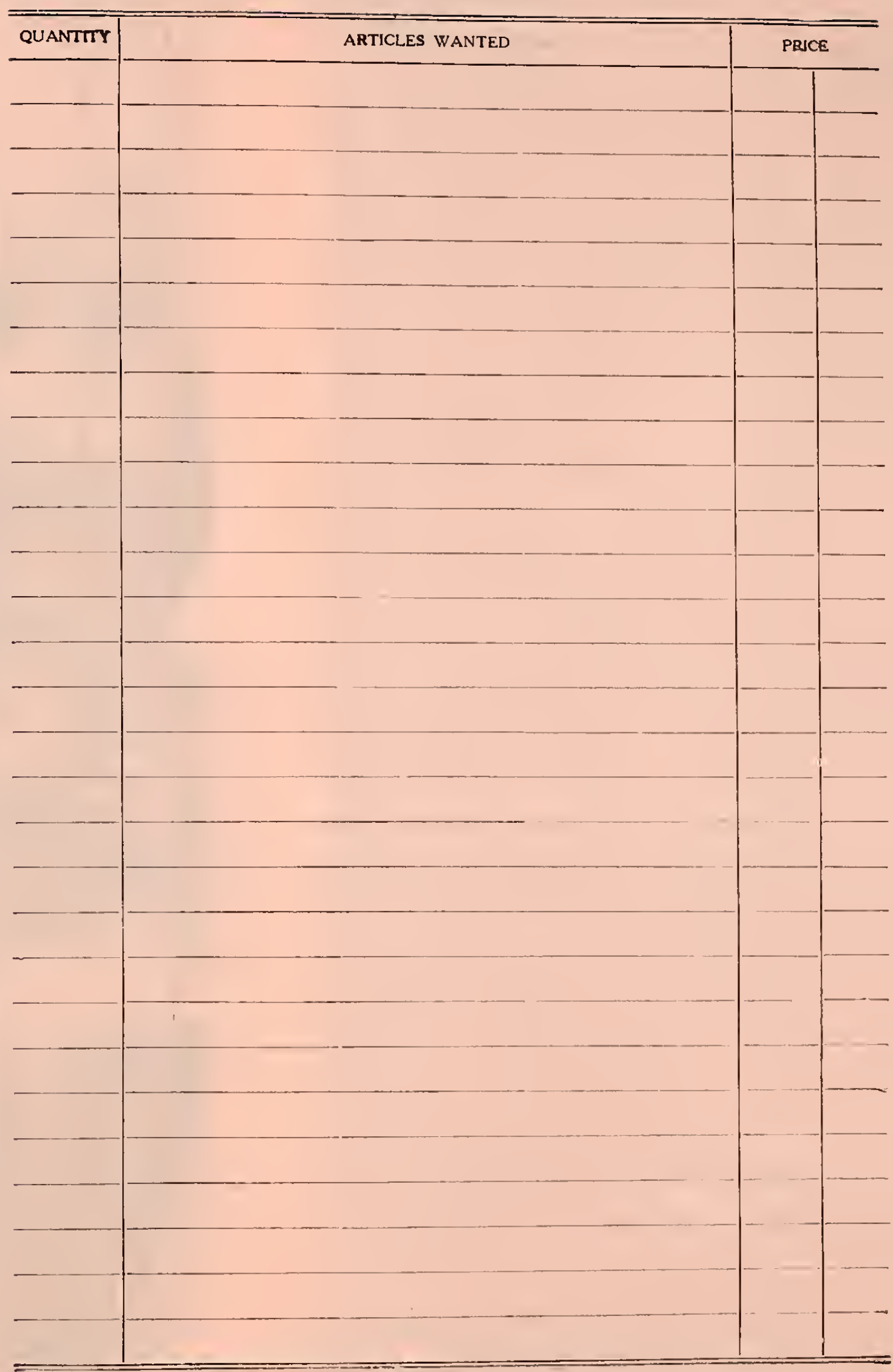




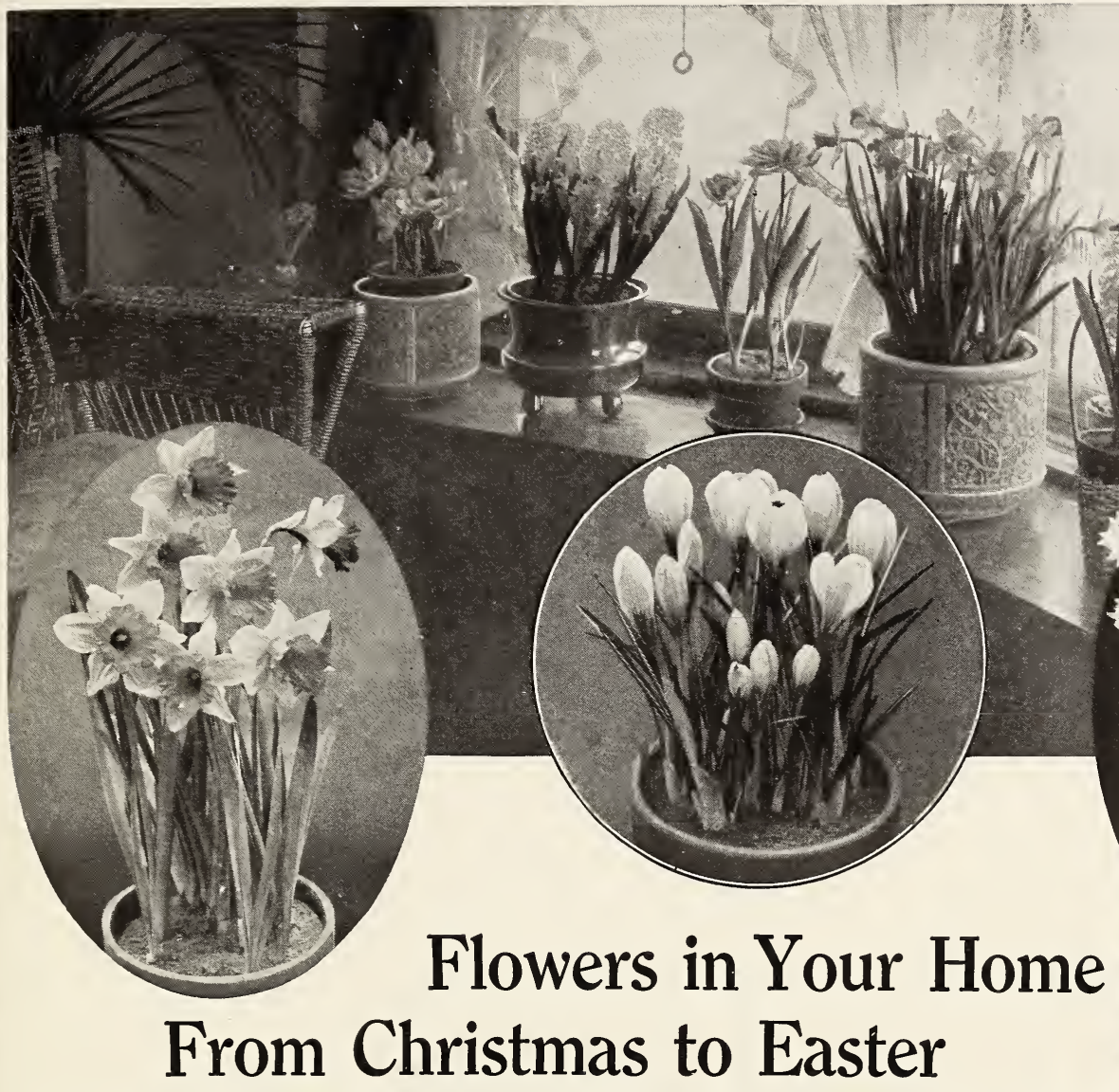

$\mathrm{O}$

$\mathrm{NE}$ of the most inspiring influences of the home is the flowers one grows. You can have an abundance of bulbs in flower from before Christmas until Easter if you plant a few bulbs suggested on this page. Six Paper-White Narcissus bulbs planted in a dish of pebbles will flower in ten weeks. The best Paper-White Narcissus bulbs cost $\$ 7$ per Ioo, and these flowers are sold in the florists' shops at $\$ 2$ to $\$ 2.50$ per dozen. You can grow your own and not only enjoy the fun of it, but save three profits-the grower's, the wholesale cut-flower dealer's, and the florist's.

SOIL AND CULTURE. The soil for potting bulbs should be light and rich; one-half good garden soil, one-fourth sand, and one-fourth rotted stable manure is about right, and this should then be thoroughly mixed and pulverized before using.

The pots, after placing part of a broken pot at the bottom to ensure drainage, should be filled to within 4 inches of the top, bulbs set in 2 to 4 inches apart, according to the variety, and then soil placed around them, just allowing the top of the bulb to protrude. After planting, water thoroughly, place in the coolest, darkest part of the cellar, away from the heat and light. Freezing will not hurt them. While in the cellar, look at occasionally and see that soil is moist not wet. The main point to consider is to be sure they have made plenty of roots before being brought up to the living-room. The Paper-White Narcissi, Freesias, and Crocuses offered on this page, planted October I5, may be brought to light December I, and, in order to have them in succession, bring up a pot or pan every week until you have brought all your stock in. Early Tulips, Daffodils, and Hyacinths brought in January I 5 should begin flowering from March Io on.

\section{Special List for Pot Culture}

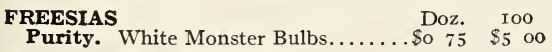

CROCUSES (Selected Bulbs)

Purpurea Grandiflora. Blue....... $40 \quad 250$

Kathleen Parlow. White......... 40 . 250

La Majestueuse. White. striped purple...

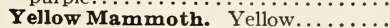

TULIPS

Rising Sun. The finest yellow....... Belle Alliance. Scarlet.

White Hawk. Fine white

Keizerkroon Red and yellow ..........

Princess Wilholmina. Dark pink ...
DUTCH HYACINTHS (First Size)

One Bulb suggested for 5 -inch pot; 4 for an 8 -inch pot or pan. Lady Derby. Finest pink. La Victoire. Finest red..... City of Haarlem. Finest yellow. La Grandesse. Finest white.

NARCISSI or DAFFODILS largest bulbs only)

Paper-White. White.....

Golden Spur. Ri

Emperor. Yellow............

Empress. Yellow and white.

Von Sion. Double yellow

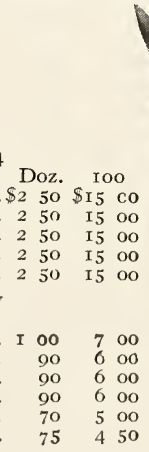

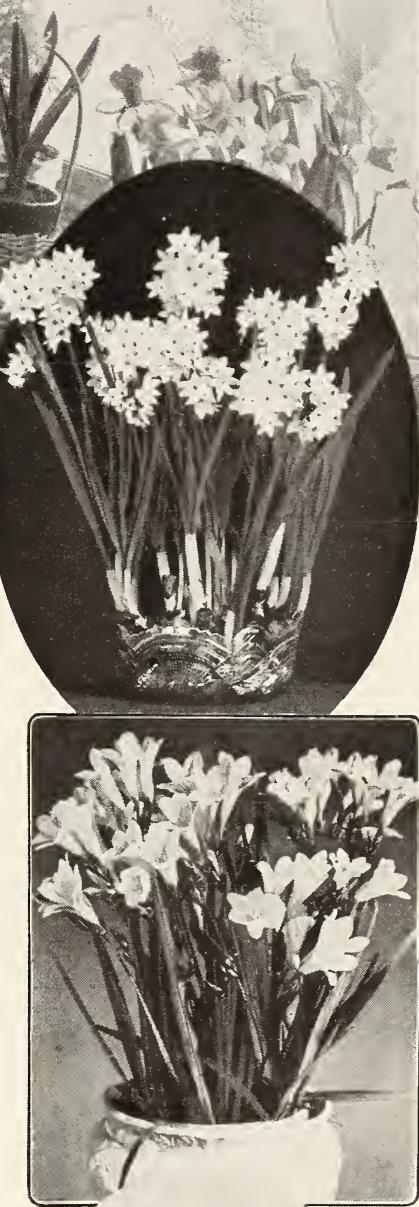

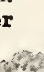

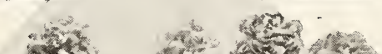

?
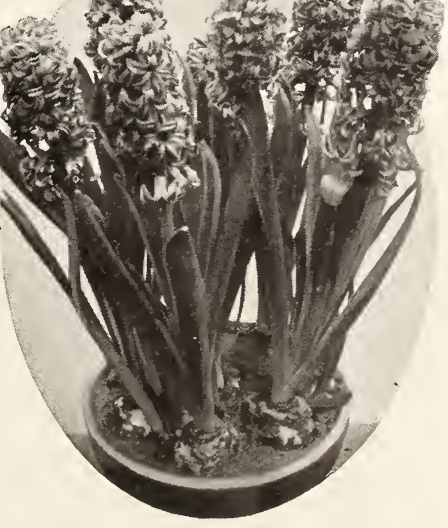


\section{ADVANCE OFFERING}

\section{DAFFODILS FOR NATURALIZING}

There is no more useful bulbous plant than the Daffodil for planting around the home-grounds. They are equally at home in the shady location of your shrubbery border or planted in clumps in your flower-border. They are not subject to any particular rodent or pest, and usually increase in numbers every year.

After 1925, they will not be allowed entry into our country. Ninety-five per cent of these beautiful bulbous plants are imported every year from Holland. We suggest to our patrons the advisability of planting liberal quantities each year until the quarantine against their importation becomes effective.

We have arranged with our growers to produce large stocks of the best named varieties and to prepare a mixture of the best varieties for outdoor planting.

Giant Trumpets, in Mixture. $\$ 4$ per $100, \$ 35$ per $1,000, \$ 325$ per 10,000 .

Medium Trumpets, in Mixture. $\$ 4$ per $100, \$ 35$ per $1,000, \$ 325$ per 10,000 .

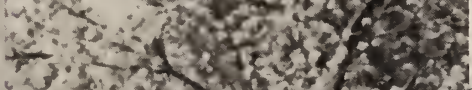

STUMPP \& WALTER CO., 30-32 Barclay St., New York City

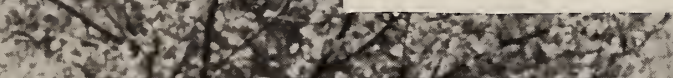

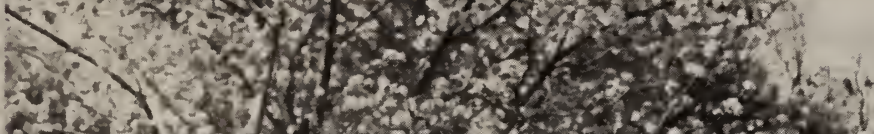

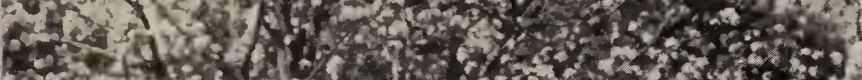

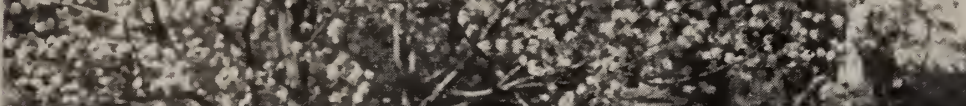
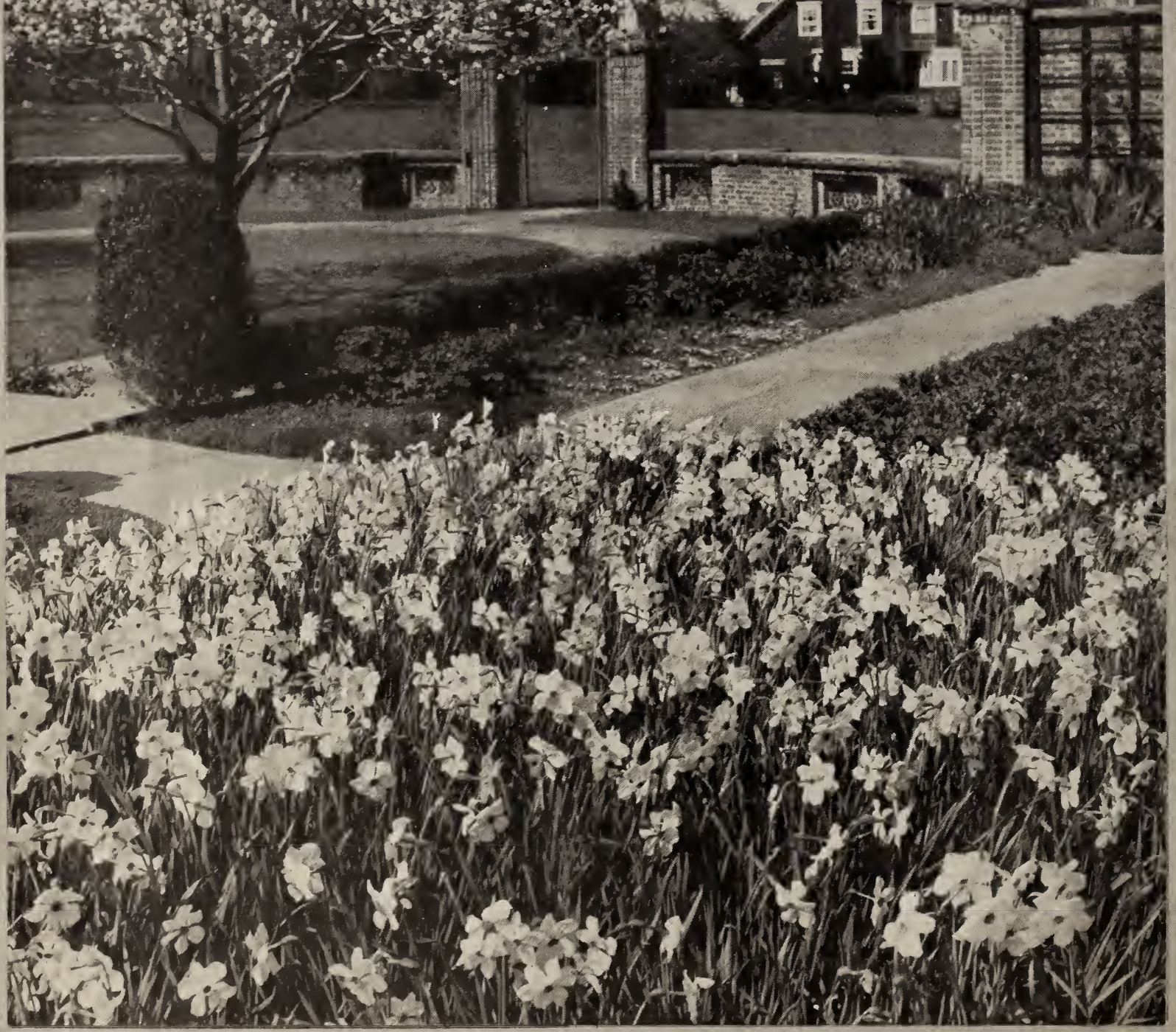